\title{
Integration from Retail Banking to Non-Financial Corporations in EMU
}

\author{
Sanjay Sehgal \\ Department of Financial Studies, University of Delhi, India \\ Priyanshi Gupta \\ Department of Management, Bengaluru, Amrita Vishwa Vidyapeetham, Amrita University, India \\ Florent Deisting \\ Groupe ESC Pau, Pau, France
}

\begin{abstract}
This paper investigates the integration process within the European Economic and Monetary Union's retail banking industry by analyzing deposit and lending rates to nonfinancial corporations. The investigation covers the 2003 2014 period, examining the normal period, the global crisis period, and the European debt crisis period. The paper classifies sampled countries into three groups on the basis of their Gross Domestic Product to investigate the relationship between economic size and degree of integration. We employ five different indicators to assess various dimensions of integration: beta convergence, sigma convergence, variance ratio, asymmetric dynamic conditional correlation, and dynamic co-integration. The results point toward a weak degree of integration, which was worsened by the twin crises. In addition, results indicate that more heterogeneity exists in the credit market than in the deposits market. Furthermore,
\end{abstract}

\footnotetext{
* Corresponding Author: Priyanshi Gupta; Department of Management, Bengaluru, Amrita Vishwa Vidyapeetham, Amrita University, Campus Kasavanahalli, Carmelaram P.O. Bengaluru - 560 035, India; Tel: +91 8879252473 , E-mail: priyanshiguptadu@gmail.com.

Co-authors: Sanjay Sehgal; Department of Financial Studies, University of Delhi, South Campus, Benito Juarez Road, New Delhi, 110021, India; Tel: +919891199840, E-mail: sanjayfin15@yahoo.co.in.

Florent Deisting; Group ESC Pau, Département Acadadémique Finance-Economie, 3 Rue Saint-John Perse, 64000 Pau, France; Tel: +33 (0)0559923344, E-mail: florent.deisting@esc-pau.fr.
} 
short-term maturity products are observed to be more converged than longer-term maturity products. We also observe a positive relationship between economic size of sampled countries and the degree of retail banking integration.

JEL Classifications: C22, F36, G15, G21

Keywords: Economic and Monetary Union, Retail Banking to Non-Financial Corporations, Global Financial Crisis, Eurozone Debt Crisis, Time-Varying Retail Banking Integration.

\section{Introduction}

In European economies, financing is strongly bank-based with banks contributing about 75-80\% of it (Wehinger 2012, Langfield and Pagano 2015). This is particularly true for Small and Medium Enterprises (SMEs) as they are often excluded from capital markets owing to their size and limited financial sophistication, while having access to bank financing (ECB 2013). Considering the importance of retail banking in this region, in October 2012 the European Summit agreed on a broad outline of a European Banking Union based on the following three pillars: a Single Supervisory Mechanism (SSM), a Single Resolution Mechanism (SRM), and eventually, a common Deposit Guarantee Scheme (DGS). While the idea of a banking union is widely appreciated, it is important to examine the effectiveness of policy initiatives undertaken so far (see Table 1) toward forging an integrated European banking system. In addition, given the gravity of the recent Global Financial Crisis (GFC) and the European Debt Crisis (EDC), it is important to investigate their impact on banking sector integration in Europe. The contagion of the sovereign debt crisis spread into the European banking system through its exposure to toxic assets, sovereign debt holdings of fundamentally weak economies and the inefficiency of subsequent policy measures, thus turning the debt crisis into a full-fledged banking crisis. This had far-reaching implications for the real economies, which rely on the banking sector for credit and liquidity. Thus, this study aims to assess the time-varying degree of the euro-area's retail banking integration during normal and crisis periods, with a focus on Non-Financial Corporations (NFCs). In addition, we also examine whether the degree of retail banking integration varies across different 
economy sizes. For this purpose, the Economic and Monetary Union (EMU) economies are classified into three groups (A, B, and C) based on their economic size measured by Gross Domestic Product (GDP).

The Non-Financial Corporations (NFC) contribute the highest share to gross value added (58\%) and gross savings (49\%). In addition, the overall growth of gross capital formation is driven mainly by the NFC sector with a contribution of $54 \%$. Given the importance of NFC segment, as a client of retail banking, the study focuses on an indepth analysis of convergence of the deposit and credit rates in this segment with varying maturities.

\section{Table 1. Legislation on the EU banking and financial sectors}

\begin{tabular}{|l|l|}
\hline 1977 & $\begin{array}{l}\text { First Banking Directive: Removed obstacles to the provision of services and } \\
\text { establishment of branches across the borders of EU member states. Harmonized } \\
\text { rules for bank licensing. Established European Union(EU)-wide supervisory } \\
\text { arrangements }\end{array}$ \\
\hline 1988 & $\begin{array}{l}\text { Basle Capital Adequacy Regulation (Basle I): Minimum capital adequacy } \\
\text { requirements for banks (8\% ratio). Capital definitions: Tier 1 (stock); Tier 2 (near- } \\
\text { stock). Risk-weightings based on credit risk for bank business }\end{array}$ \\
\hline 1988 & $\begin{array}{l}\text { Directive on Liberalization of Capital Flows: Free cross-border capital flows, } \\
\text { with safeguards for countries with balance of payments problems }\end{array}$ \\
\hline $\begin{array}{l}\text { Second Banking Directive (Single EU banking licence): Principles of home } \\
\text { country control (home regulators have ultimate supervisory authority for the } \\
\text { foreign activity of their banks) and mutual recognition (EU bank regulators } \\
\text { recognise equivalence of their regulations). Passed in conjunction with the Own } \\
\text { Funds and Solvency Directives, incorporating capital adequacy requirements } \\
\text { similar to Basle I into EU law }\end{array}$ \\
\hline 1992 & $\begin{array}{l}\text { Maastricht Treaty broadens the EC into the EU, with a commitment to EMU, } \\
\text { including the creation of the Euro }\end{array}$ \\
\hline 1992 & $\begin{array}{l}\text { Large Exposures Directive: Banks should not commit more than 25\% of their } \\
\text { own funds to a single investment. Total resources allocated to a single investment } \\
\text { should not exceed } 800 \% \text { of own funds }\end{array}$ \\
\hline
\end{tabular}

Eurostat (2015). Contributions of Each Institutional Sector to Macroeconomic Developments. http://ec.europa.eu/eurostat/web/ sector-accounts/detailed-charts/contributions- sectors 


\begin{tabular}{|c|c|}
\hline 1993 & $\begin{array}{l}\text { Investment Services Directive: Legislative framework for investment firms and } \\
\text { securities markets, providing for a single passport for investment services }\end{array}$ \\
\hline 1994 & $\begin{array}{l}\text { Directive on Deposit Guarantee Schemes: Minimum guaranteed investor } \\
\text { protection in the event of bank failure }\end{array}$ \\
\hline 1998 & Creation of the European Central Bank (ECB) \\
\hline 1999 & $\begin{array}{l}\text { Financial Services Action Plan (FSAP: Legislative framework for the Single } \\
\text { Market in financial services. FSAP was launched in } 1999 \text { to be implemented in } \\
\text { 2005. This plan had three aims: the creation of a single EU wholesale market for } \\
\text { financial services and products, the creation of an open and secure financial retail } \\
\text { market, and the implementation of state of the art prudential rules and supervision }\end{array}$ \\
\hline 2000 & Consolidated Banking Directive: Consolidation of previous banking regulation \\
\hline 2000 & $\begin{array}{l}\text { Directive on e-money: Access by non-credit institutions to the business of } \\
\text { e-money issuance. Harmonised rules/standards relating to payments by mobile } \\
\text { telephone, transport cards, and Basle payment facilities }\end{array}$ \\
\hline 2001 & $\begin{array}{l}\text { Directive on the Reorganisation and Winding-Up of Credit Institutions: Recognition } \\
\text { throughout EU of reorganisation measures/winding-up proceedings by the home } \\
\text { state of an EU credit institution }\end{array}$ \\
\hline 2001 & $\begin{array}{l}\text { Regulation on the European Company Statute: Standard rules for company formation } \\
\text { throughout the EU. Permits the formation of a single legal entity that can operate } \\
\text { freely across EU national borders }\end{array}$ \\
\hline 2002 & $\begin{array}{l}\text { Financial Conglomerates Directive: Supervision framework for a group of } \\
\text { financial entities engaged in cross-sectoral activities (banking, insurance, } \\
\text { securities) }\end{array}$ \\
\hline 2004 & New EU Takeover Directive: Common framework for cross-border takeover bids \\
\hline $\begin{array}{l}2005 \sim \\
2010\end{array}$ & $\begin{array}{l}\text { White paper on Financial Services Policy: Plan to implement outstanding FSAP } \\
\text { measures, consolidation/convergence of financial services regulation and supervision }\end{array}$ \\
\hline $\begin{array}{l}2006 \\
2008\end{array}$ & $\begin{array}{l}\text { Capital Requirements Directive: Updates Basle I and incorporates the measures } \\
\text { suggest in the International Convergence of Capital Measurement and Capital } \\
\text { Standards (Basle II). Improved consistency of international capital regulations. } \\
\text { Improved risk-sensitivity of regulatory capital. Promotion of improved risk- } \\
\text { management practices among international banks. }\end{array}$ \\
\hline
\end{tabular}




\begin{tabular}{|l|l|}
\hline 2011 & $\begin{array}{l}\text { The implementation of the Capital Requirements Directive III (CRD III), known } \\
\text { as the Basel } 2.5 \text { regulatory framework, on 31 December 2011. Resulted in higher } \\
\text { capital requirements for banks, in particular by applying considerably higher risk } \\
\text { weights both to securitisations in the trading book and to market risks measured } \\
\text { via internal models. }\end{array}$ \\
\hline 2011 & ECB institutes LTRO program to provide three-year liquidity for banks \\
\hline 2012 & Second batch of three-year LTRO loans takes total lent to more than $€ 1$ trillion \\
\hline 2012 & European Summit agree on a broad outline of European Banking Union \\
\hline 2013 & ECB to begin taking on overall supervisory role for Eurozone banks \\
\hline 2014 & ECB to be fully effective as bank supervisor \\
\hline 2015 & $\begin{array}{l}\text { The European Commission launched the Capital Markets Union Action Plan } \\
\text { towards a true single market for capital across the 28 EU Member States. }\end{array}$ \\
\hline
\end{tabular}

(Source) Goddard, Molyneux, Wilson, and Tavakoli (2007) and author's updates.

The extant literature on integration maintains that financial integration is evolving at a different pace across financial instruments and services. While most researchers find some evidence of integration in wholesale banking and capital market activities (Baele et al. 2004, Gupta et al. 2015, Sehgal et al. 2016), there is scepticism regarding retail banking integration despite the presence of a single currency and a common central bank (Cabral, Dierick and Vesala 2002, Heinemann and Jopp 2002, Eppendorfer, Beckman and Neimke 2002, Schuler and Heinemann 2002). This is attributed to non-regulatory barriers of integration such as preferences for proximity, variation in credit products, and cultural differences across borders.

One strand of literature on banking system integration uses the convergence level of interest rates for evaluating integration in banking in the EMU. Studies such as those by Baele et al. (2004) and Vajanne (2007) apply beta and sigma convergence measures to retail interest rate levels. Baele et al. (2004) report convergence for the pre-EMU as well as the EMU period but find a significant increase in convergence only for mortgages under a single currency. Affinito and Farabullini (2006) compare bank rate differentials and show that the degree of integration in the Italian banking system is higher than that in the euro area. The authors conclude that further convergence can happen if banking services become more similar. Kleimeier and Sander (2006) apply co-integration measures to conclude that Eurozone convergence is at least partly a global process 
and has largely been a result of integrating the wholesale markets of the region after eliminating exchange rate risks. Studies show that the credit market, in general, is far more heterogeneous than the savings market, (Martín-Oliver, Salas-Fumás and Saurina 2005, Rughoo and Sarantis 2012, Rughoo and Sarantis 2014) which can be attributed to heterogeneity in the credit policies of banks.

The second strand uses quantity-based indicators to measure the progress made in the banking integration process. In their pioneer work, Cabral, Dierick, and Vesala (2002) analyze banking integration in the following three areas: wholesale, capital market, and retail. While the results indicate a fully integrated market in wholesale banking services, the integration process has clearly been slower in the retail area, which is because of the traditionally strong local nature of these activities. As for the capital market, while intermediating bond issuance is observed to be significantly integrated, intermediating stock issuance and large-scale lending have remained local because of the greater role of local information and risk assessment. Manna (2004) uses cross-border quantity flows for several banking assets to conclude that in retail markets, with the exception of the home bias, an increasing neutrality toward the location of the counterparty is present. Perez, Vicente and Saurina (2005) found evidence that a cross-country flow of banking assets in the Eurozone is progressing at a faster pace after the introduction of the euro, which has changed the pace and trend of European banking integration.

In addition, banking integration has also been investigated by studying the convergence of returns on assets and profitability (Gropp and Kashyap 2009, Ilut and Chirlesan 2012), convergence of cost efficiencies (Weill 2009, Casu and Girardone 2010), and interest rate pass-through (e.g., Sander and Kleimeier 2004). While the convergence of returns on assets of banks across the EMU is not observed despite the juridical and political efforts undertaken in Europe, the evidence of convergence in cost efficiency of banks across European countries is attributed to lagging behind rather than catching up with best practices. Convergence in efficiency is expected to accelerate in future with a greater number of cross-border mergers and acquisitions. Similarly, Sander and Kleimeier (2004) found that heterogeneity across the Eurozone has decreased in some banking markets. However, as legal and cultural differences at the national level remain important, convergence remains incomplete and monetary policy will continue to operate in a heterogeneous Eurozone.

Given the important role of bank-based financing in the euro area, banks are conveyors of monetary policy impulses and form an important intermediary for business and trade. Thus, banking integration has far-reaching implications for uniform 
transmission of monetary policy in the region as well as for the financing of firms. It also has a bearing on the nature and extent of cross-border banking transactions, risk diversification, and the availability and cost of bank loans. As integration reduces credit constraints, it also encourages excessive leverage. In addition, in recent times, the subject of banking integration has garnered a lot of importance, particularly in the backdrop of the recent financial crises. Considering this, the main objectives of this study are as follows:

- To measure different dimensions of time-varying integration in retail banking with a focus on NFCs;

- To assess the change in the degree of integration of retail banking, especially NFCs, between normal and crises periods; and

- To examine the variation in the degree of integration of retail banking, particularly NFCs, across different groups of EMU members, classified by the size of their economies.

This study should be of interest to the central bank, policy makers, academicians, investors, and portfolio managers. The following section briefly discusses the EMU retail banking industry.

\section{A. EMU banking industry}

Table 2 provides an overview of the banking sector across different members of the EMU. The table shows that the depth of the banking market as measured by the ratio of total assets to GDP as well as of domestic credit to GDP is relatively high across countries. In terms of the banking assets to GDP ratio, Luxembourg has the largest banking sector, with its banking sector being driven by foreign banks, while for most other economies, the focus is on domestic operations (ECB 2013). 
Table 2. Economic size and banking sector

\begin{tabular}{|c|c|c|c|c|c|c|}
\hline \multirow{2}{*}{ Group } & \multirow{2}{*}{ Country } & \multirow{2}{*}{$\begin{array}{c}\text { GDP } 2014 \\
\text { (billions of } \\
\text { euro) }^{\mathrm{a}}\end{array}$} & \multirow{2}{*}{$\begin{array}{c}\text { Year } \\
\text { of joining } \\
\text { EMU }\end{array}$} & \multirow{2}{*}{$\begin{array}{l}\text { Symbol } \\
\text { used }\end{array}$} & \multicolumn{2}{|c|}{$\begin{array}{c}\text { Total banking assets to GDP } \\
\text { ratio (2014) }\end{array}$} \\
\hline & & & & & $\begin{array}{c}\text { Domestic } \\
\text { banks }\end{array}$ & $\begin{array}{l}\text { Foreign subsidiaries } \\
\text { and branches }\end{array}$ \\
\hline \multirow{6}{*}{$\begin{array}{c}\text { Group } \\
\text { A }\end{array}$} & Germany & 2734.26 & 1999 & Ger & 2.3 & 0.1 \\
\hline & France & 2060.872 & 1999 & Frc & 3.2 & 0.2 \\
\hline & Italy & 1537.125 & 1999 & Ita & 1.5 & 0.1 \\
\hline & Spain & 1053.296 & 1999 & Spn & 3.2 & 0.2 \\
\hline & Netherlands & 638.498 & 1999 & Net & 3.6 & 0.3 \\
\hline & Belgium & 393.453 & 1999 & Bel & 1.2 & 1.2 \\
\hline \multirow{5}{*}{$\begin{array}{c}\text { Group } \\
\text { B }\end{array}$} & Austria & 307.257 & 1999 & Aus & 2.3 & 1 \\
\hline & Greece & 186.541 & 2001 & Grc & 2 & 0.1 \\
\hline & Finland & 186.295 & 1999 & Fin & 0.8 & 2 \\
\hline & Portugal & 167.841 & 1999 & Por & 2 & 0.5 \\
\hline & Ireland & 188.778 & 1999 & Ire & 1.4 & 1.3 \\
\hline \multirow{6}{*}{$\begin{array}{l}\text { Group } \\
\text { C }\end{array}$} & Slovakia & 72.84 & 2009 & Sla & 0.1 & 0.7 \\
\hline & Luxembourg & 44.396 & 1999 & Lux & 1.9 & 14.3 \\
\hline & Slovenia & 36.191 & 2007 & Sle & 0.7 & 0.4 \\
\hline & Cyprus & 15.008 & 2008 & Сур & 2.8 & 1.5 \\
\hline & Estonia & 17.408 & 2011 & Est & 0.1 & 1.1 \\
\hline & Malta & 7.31 & 2008 & Mal & 1.9 & 4.7 \\
\hline
\end{tabular}

(Notes) (i) The table shows only those member countries that form part of the sample set for this study.

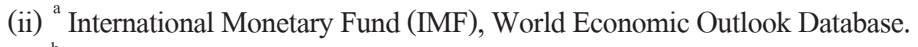

${ }^{\mathrm{b}}$ ECB Report on Financial Structures, October 2015.

ECB (2013) reports that although the total assets of the euro-area banking sector declined following the balance sheet repair and structural change post-crisis, banks in the Eurozone are still holding on to assets that are three times the size of the currency bloc's economy. Over the past three decades, policy makers have initiated multiple steps for the development and integration of the banking system across EU's members, toward 
the goal of creating a single financial market in the union. Table 1 presents an overview of the important legislative developments in creating regulatory harmonization across banking and financial markets.

Despite the policy measures undertaken to create a banking union, the retail-banking sector in the EMU remains fragmented, even though studies indicate that the money market and capital markets (stock and bond) have experienced considerable integration over time. It is important to note that low retail-banking integration across countries hampers the functioning of a central monetary authority as it results in limited and unequal monetary transmission across the member countries. Studies show that the passthrough of policy rates down to the bank interest rates is relatively low in Europe (Campa and Gozalez Minguez 2006) with a lack of integration in retail banking being one of the major factors (Bondt et al. 2005, Kleimeier and Sander 2006).

The rest of the paper is organized as follows: Section II describes the dataset. Section III details the methodology. Section IV presents the results. Finally, Section V provides the summary and the conclusions.

\section{Data}

This study covers 17 EMU member countries, which are classified into three groups (A, B, and C) based on their economic size measured by GDP (Table 2). Belgium (Bel), France (Frc), Germany (Ger), Italy (Ita), Netherlands (Net), and Spain (Spn) are grouped under Group A; Austria (Aus), Finland (Fin), Greece (Grc), Ireland (Ire), and Portugal (Por) are classified under Group B; and Cyprus (Cyp), Estonia (Est), Malta (Mal), Slovakia (Sla), Luxembourg (Lux), and Slovenia (Sle) constitute Group C. This is done to test the generally held view that large economies are more likely to integrate with other economies owing to higher cross-border capital flows as they typically have more stable macroeconomic policies, lower credit and liquidity risk, a better financial and institutional architecture and deeper markets.

We use the lending and deposit rates from the harmonized ${ }^{2}$ monthly Monetary

\footnotetext{
2 In a harmonized database, the bank interest rate series within each instrument category is based on the same definitions and classifications across all member countries. Hence, there is no inherent heterogeneity in the data unlike the bank interest rate statistics before 2002 .
} 
Financial Institutions (MFI) interest rates database of ECB. The data is compiled for sample euro area countries from January 2003 to February 2014.

In total, we consider six monthly deposit and lending interest rate data sets for NFCs. Following Rughoo and Sarantis $(2012,2014)$, we employ three maturities, namely short term, medium term, and long term. The following datasets are compiled:

- Deposit rates with maturities up to one year, up to two years, and more than two years; and

- Loans with maturities up to one year, one-five years, and more than five years.

The total sample period is divided into two sub-periods, the Normal period from January 2003 to July 2007 and the Crisis period from August 2007 to February 2014. The Crisis period starts from August 9, 2007 (see for e.g., Trichet 2010, Angelini, Nobili and Picillo 2011, Simplice 2012). Although the Eurozone reported an end of the recession in the first quarter of 2013, in February 2014, three countries - Cyprus, Italy, and Greece ${ }^{3}$ - were still in recession.

We check the stationarity of the data series by conducting the Augmented DickeyFuller test (ADF). The results are reported in Table 3, which show that all the series are integrated of order one- (I (1)). This is similar to previous studies (Buttner and Hayo 2010, Tamakoshi and Hamori 2012, Buchholz and Tonzer 2013).

\footnotetext{
${ }^{3}$ Eurostat. GDP and main components - volumes: Percentage change on previous quarter (seasonally adjusted, and adjusted by working days).
} 


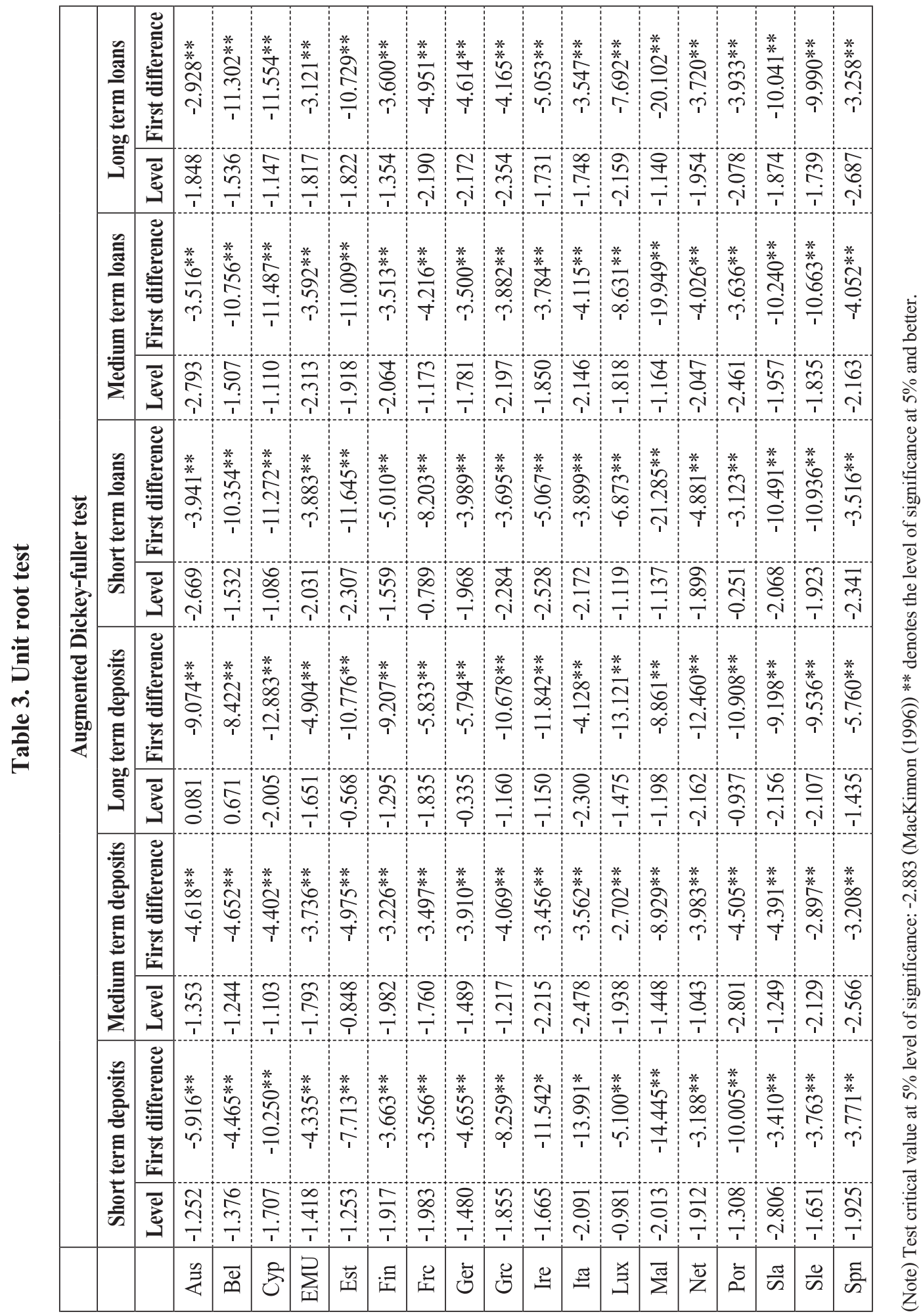




\section{Methodology}

Retail integration is measured by employing five different indicators, each with a different focus, namely beta convergence (speed of convergence), sigma convergence (cross-sectional dispersion), Variance ratio (variance from common source), Asymmetric Dynamic Conditional Correlation, hereafter called ADCC (time-varying correlation) and dynamic co-integration (time-varying long-run relationship). As the tests established breaks in the time series, all the measures of integration in this study incorporate rolling estimation to capture the time-varying dynamics of retail banking integration. Table 4 provides a brief overview of the indicators employed for measuring integration.

Table 4. Indicators of integration

\begin{tabular}{|c|c|}
\hline Measure & Relation to financial integration \\
\hline 1. Beta convergence & $\begin{array}{l}\text { A negative Beta coefficient implies convergence. The estimated } \\
\text { value of Beta indicates the speed of convergence. }\end{array}$ \\
\hline 2. Sigma convergence & $\begin{array}{l}\text { Lower cross-sectional dispersion from benchmark (EMU), as } \\
\text { measured by sigma value, implies higher return convergence. }\end{array}$ \\
\hline 3. Variance ratio & $\begin{array}{l}\text { Higher EMU Variance ratio implies more important role of } \\
\text { regional factors than local factors in explaining country } i \text { 's rates }\end{array}$ \\
\hline $\begin{array}{l}\text { 4. Asymmetric } \\
\text { dynamic conditional } \\
\text { correlation Model }\end{array}$ & $\begin{array}{l}\text { A higher time-varying dynamic correlation indicates greater } \\
\text { co-movement of returns. Significant coefficient of asymmetric } \\
\text { impact implies the presence of impact of joint bad news on } \\
\text { correlations. }\end{array}$ \\
\hline $\begin{array}{l}\text { 5. Dynamic } \\
\text { co-integration }\end{array}$ & $\begin{array}{l}\text { - Scaled trace statistic consistently greater than one is an indicator } \\
\text { of long run relationships between the indices. } \\
\text { - Higher the absolute value of rolling coefficient of Error Correction } \\
\text { Term (ECT), higher is the speed of adjustment to long run } \\
\text { equilibrium, and hence greater convergence. }\end{array}$ \\
\hline
\end{tabular}

(Note) This table provides an overview of the different indicators of integration that are used for the purpose of this study. The indicator of dynamic co-integration consists of two measures to assess the degree of integration, which provide different information about the integration. 


\section{A. Beta convergence}

Barro and Sala-I-Martin (1992) pioneered the concept of beta convergence to measure the convergence of levels of growth across economies. While the absolute value of beta indicates the speed at which the interest rates of country $i$ converge toward the interest rates at the Euro area level, the negative sign of the beta coefficient indicates mean reversion of rates and hence the presence of convergence. Beta convergence is quantified by estimating the following regression:

$$
\Delta E R_{i, t}=\alpha_{i}+\beta_{i, t} E R_{i, t-1}+\sum_{l=1}^{L} \gamma_{l} \Delta E R_{i, t-1}+\varepsilon_{i, t}
$$

where $E R_{t}$ represents the interest rate differential between country $i$ and the Eurozone at time $t$. In the ideal situation of perfect retail banking integration, this interest rate differential should be zero following the law of one price. Therefore, a negative $\beta_{t}$ coefficient indicates mean reversion taking place in the retail banking sector across economies. An absolute value of the coefficient represents the speed of convergence at which the interest rate differential is dissolved and interest rates in country $i$ converge with those of the benchmark. Thus, $\beta_{t}$ is the convergence coefficient. A negative coefficient means that convergence takes place. The larger the absolute values of beta are, the faster is the convergence. The lag length $l$ is determined using the Schwarz Information Criteria (SIC). The beta coefficient is varied according to the time using the rolling regression technique with a fixed window of 65 trading days, which approximates to one quarter. Under the null hypothesis of no convergence, $\beta$ is equal to zero.

\section{B. Sigma convergence}

Beta convergence and sigma convergence form the twin pillars of convergence growth literature. Sigma convergence appraises the extent to which markets are already integrated. In essence, it gauges the cross-sectional dispersion of interest rates relative to the benchmark. This measure, in principal, tests whether the law of one price holds good. The law states that if the economies are to be integrated, returns on assets with identical structures should be equalized across these economies. The value of sigma is estimated as follows: 


$$
\sigma_{i, t}=\sqrt{N^{-1} \sum_{i=1}^{N}\left[I_{i, t}-I_{b, t}\right]^{2}}
$$

where $I_{i, t}$ and $I_{b, t}$ are the interest rates of country $i$ and the benchmark (Eurozone) respectively. $N$ is the number of economies considered in the analysis. To gauge the progress of cross-sectional convergence over time, we undertake estimation over the rolling samples of 65 days each for each country. The value of sigma is always positive. A high value of sigma indicates a very low degree of integration and a sigma equal to zero indicates full integration.

\section{Variance ratio}

The variance ratio represents the proportion of local interest rate changes that can be explained by common factors. In an integrated system, the interest rates across countries should react to common shocks and local news should play only a marginal role in explaining the variance. Thus, in an integrated banking system, change in the Eurozone interest rate should drive the corresponding local interest rates across member countries.

First, we estimate the following regression to separate common news from local shocks.

$$
\Delta r_{i, t}=\alpha_{i, t}+\beta_{i, t} \Delta r_{E M U, t}+\varepsilon_{i, t}
$$

where $\Delta r_{i, t}$ represents the change in the level of a specific bank interest rate in one country and $\Delta r_{E M U, t}$ is the explanatory variable that represents the change in the level of the corresponding benchmark Eurozone interest rate. $\alpha_{i, t}$ is a time-dependent intercept, $\beta_{i, t}$ is the time-varying beta with respect to the benchmark Eurozone interest rate and $\varepsilon_{i, t}$ is the country-specific shock.

To capture the time-varying impact of cross-market innovations, this study uses the rolling regression technique with a fixed window of three months. The conditional variances in the EMU, US and country i's bond markets are assumed to follow the Exponential General Autoregressive Conditional Heteroskedastic (E-GARCH) $(1,1)$ process. From Equation (3), the total variance of country $i$ can be given as follows:

$$
\operatorname{Var}\left(\Delta r_{i, t}\right)=\beta_{i, t}^{2} \operatorname{Var}\left(\Delta r_{E M U, t}\right)+\operatorname{Var}\left(\varepsilon_{i, t}\right)
$$


The variance ratio is given as follows:

$$
\text { Euro variance ratio }\left(V R_{i, t}^{E M U}\right)=\frac{\beta_{i, t}^{2} \operatorname{Var}\left(\Delta r_{E M U, t}\right)}{\operatorname{Var}\left(\Delta r_{i, t}\right)}
$$

A variance ratio equal to unity implies full integration wherein only regional news should drive local interest rates.

\section{Asymmetric dynamic conditional correlation model}

A higher correlation implies that markets are integrated through the co-movement of interest rates. As a static measure of correlation is inadequate to measure integration across different sub-periods, we use the Asymmetric DCC-EGARCH (ADCC-EGARCH) model introduced by Cappiello et al. (2006) which accounts for heteroscedasticity and continuously adjusts for the time-varying volatility. While, ADCC accounts for the asymmetry in correlations that are observed to increase more after a joint negative shock ${ }^{4}$ than a positive shock (Baumohl 2013), the Exponential GARCH (EGARCH) model accommodates the asymmetries in conditional variances of asset returns as the bad news have greater impact than the good news (Nelson 1991).

The mean equation is specified as an AR (1) process (based on SIC criteria):

$$
r_{i, t}=\alpha_{i}+\sum_{k=1}^{n} \beta_{i, k} r_{i, t-k}+\varepsilon_{t}
$$

where $r_{t}=\left(r_{i, t}, r_{E M U, t}\right)$ and $\varepsilon_{t}=\left(\varepsilon_{i, t}, \varepsilon_{E M U, t}\right), \varepsilon_{t} \mid \beth_{t-1} \sim N\left(0, H_{t}\right) . H_{t}$ is the $(\mathrm{n} \times \mathrm{n})$ conditional covariance matrix decomposed as

$$
H_{t}=D_{t} R_{t} D_{t}
$$

$R_{t}$ is the time-varying correlation matrix, $D_{t}$ is the $(\mathrm{n} \times \mathrm{n})$ diagonal matrix of timevarying standard deviations for the rates, obtained by estimating the EGARCH (1, 1) process which generates the conditional variance of the residuals from the mean

${ }^{4}$ Joint bad news refers to both returns being negative (Cappiello, Engle, and Sheppard 2006). 
equation.

The evolution of the correlation equation in the ADCC model (Cappiello et al. 2006a) is given as follows:

$$
Q_{t}=\left(1-\theta_{1}-\theta_{2}\right) \bar{Q}-g \bar{N}+\theta_{1}\left(\varepsilon_{t-1} \varepsilon_{t-1}^{\prime}\right)+\theta_{2} Q_{t-1}+g\left(\eta_{t-1} \eta_{t-1}^{\prime}\right)
$$

where $Q_{t}=\left(q_{i j, t}\right)$ is the $(\mathrm{n} \times \mathrm{n})$ symmetric positive definite matrix of $\varepsilon_{t}, \bar{Q}=E\left(\varepsilon_{t} \varepsilon_{t}^{\prime}\right)$ is the $(\mathrm{n} \times \mathrm{n})$ unconditional correlation matrix of the standardized residuals $\varepsilon_{t}, \bar{N}=E\left(\eta_{t} \eta_{t}^{\prime}\right)$ and the asymmetric term $g$ captures the periods where both markets jointly experience negative shock. The scalar parameters $\theta_{1}$ and $\theta_{2}$ are non-negative and satisfy $\theta_{1}+\theta_{2}<1$. Finally, the dynamic correlation matrix between the two series is given as follows:

$$
P_{t}=Q_{t}^{*-1} Q_{t} Q_{t}^{*-1}
$$

where $Q_{t}^{*}=\left[\sqrt{q_{i i t}}\right]$ is a diagonal matrix with the square root of the $i^{\text {th }}$ diagonal elements of $Q_{t}$ as its entries.

\section{E. Dynamic co-integration}

The long-run relationship among the markets affects the potential long-run gains from diversification (Taylor and Tonks 1989). This calls for an analysis of the longrun dynamics of retail banking integration. The co-integration analysis of long-run comovements tests for the presence of common trends in the interest rate series of country $i$ and the Eurozone. The static measure of co-integration does not consider convergence as a dynamic process. Thus, a rolling co-integration analysis with a fixed-length window is more econometrically suited since it accommodates the time-varying character of longrun relationships.

This study uses bivariate co-integration (Johansen 1991) to examine the long-run relationship between country $i$ 's interest rates and the Eurozone interest rates. Let $X_{t}$ denote a vector that includes the EMU interest rates and country $i$ 's interest rates. If the individual time series are co-integrated, vector $X_{t}$ can be expressed by an Error Correction Model (ECM):

$$
\Delta X_{t}=\sum_{k=1}^{l-1} \tau_{k} \Delta X_{t-k}+\pi \Delta X_{t-k}+\varepsilon_{t}
$$


Matrix $\pi$ can be decomposed as $\alpha \beta^{\prime}$, where matrix $\alpha$ contains the short-run adjustment ECT) coefficients of the long-run relationships (the $\beta$ matrix). The rank of $\pi$ determines $r$ (the co-integrating rank), defined as the number of co-integrating vectors.

Trace statistics $\left(L R_{\text {trace }}\right)$ and maximum eigenvalue $\left(L R_{\text {max }}\right)$ are the two test statistics for the null of co-integrating relations. The trace test and the test for maximum eigenvalue are Likelihood Ratio (LR) tests. The trace statistic for the null of the number of cointegration vectors is $r=r^{*}<k$ vs. the alternative that $r=k$ is computed as:

$$
L R_{\text {trace }}(r \mid l)=-T \sum_{k=r+1}^{l} \log \left(1-\lambda_{k}\right)
$$

where $k^{\text {th }}$ is the largest eigenvalue of the matrix in Equation (11).

The maximum eigenvalue statistic which tests the null of the number of cointegration vectors is $r=r^{*}<k$ vs. the alternative that $r=r^{*}+1$ is given by:

$$
L R_{\max }(r \mid r+1)=-T \log \left(1-\lambda_{r+1}\right)
$$

for $r=0,1,2, \ldots, l-1$.

In keeping with previous studies, between these, $\lambda_{t r}$ is preferred to $\lambda_{\max }$ (Serletis and King 1997). The rolling co-integration test statistics are calculated by setting the fixed window size as 750 trading days (approximately three years) as a wider window is ideal for co-integration analysis (Fung, Tam and Yu 2008). The window is rolled by adding one observation to the end and removing the first observation for each sample. ${ }^{5}$ The trace statistics obtained from the rolling co-integration tests are scaled by the adjusted critical values at the $5 \%$ significance level (i.e., 54.079). If the scaled trace statistic value exceeds one, it implies rejection of the null hypothesis of no co-integration, thus implying the presence of a long-run relationship.

While the trace test statistic uncovers the presence of a long-run relationship, the ECT augments this information by describing the responses of variables to deviations from this long-run equilibrium. Thus, the absolute value of the coefficient of ECT $\alpha$ measures the speed of adjustment of short-run deviations to the long-run equilibrium. An increasing speed of adjustment implies a progressively higher degree of retail banking convergence. The time-varying $\alpha$ provides an alternative, and probably more appealing measure of convergence (Mylonidis and Kollias 2010). The rolling speed of adjustment

\footnotetext{
${ }^{5}$ The authors would like to thank Dr. Nikolaos Mylonidis for providing us with his Eviews code for rolling cointegration test.
} 
coefficients are estimated based on one co-integrating vector. A comparison of the coefficients of ECTs for individual countries and the Eurozone will help understand the lead-lag relationship between the two systems.

\section{Empirical Results}

Tables 5 to Table 10 report the results for different indicators of integration. The results for the deposit sides are presented in Tables 5, Table 6, and Table 7, which show separately the results for short-term, medium-term, and long-term deposits, respectively. Similarly, the results for short term, medium-term, and long-term loans are presented in Tables 8, Table 9, and Table 10, respectively.

\section{A. Beta convergence}

Figure 1. Beta convergence of deposits

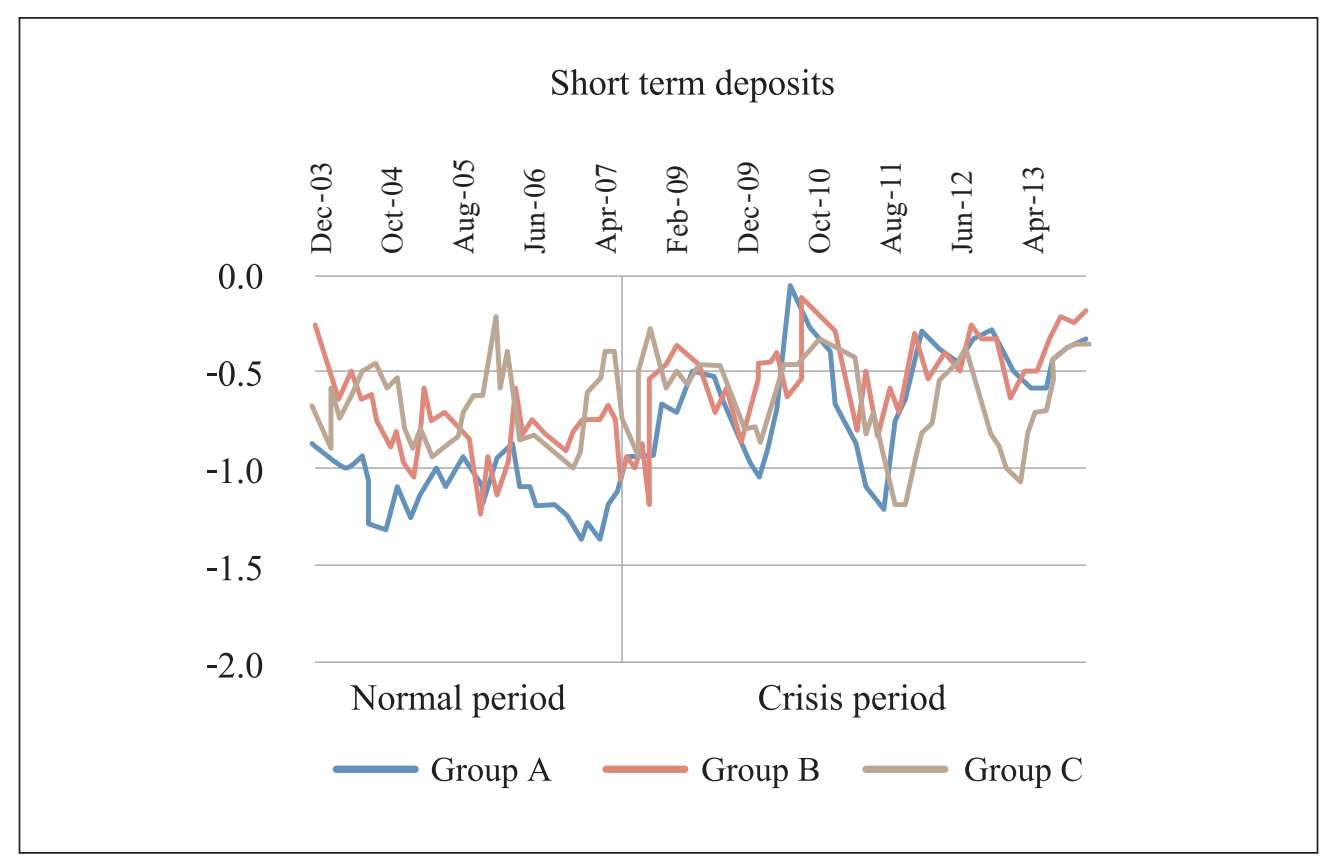



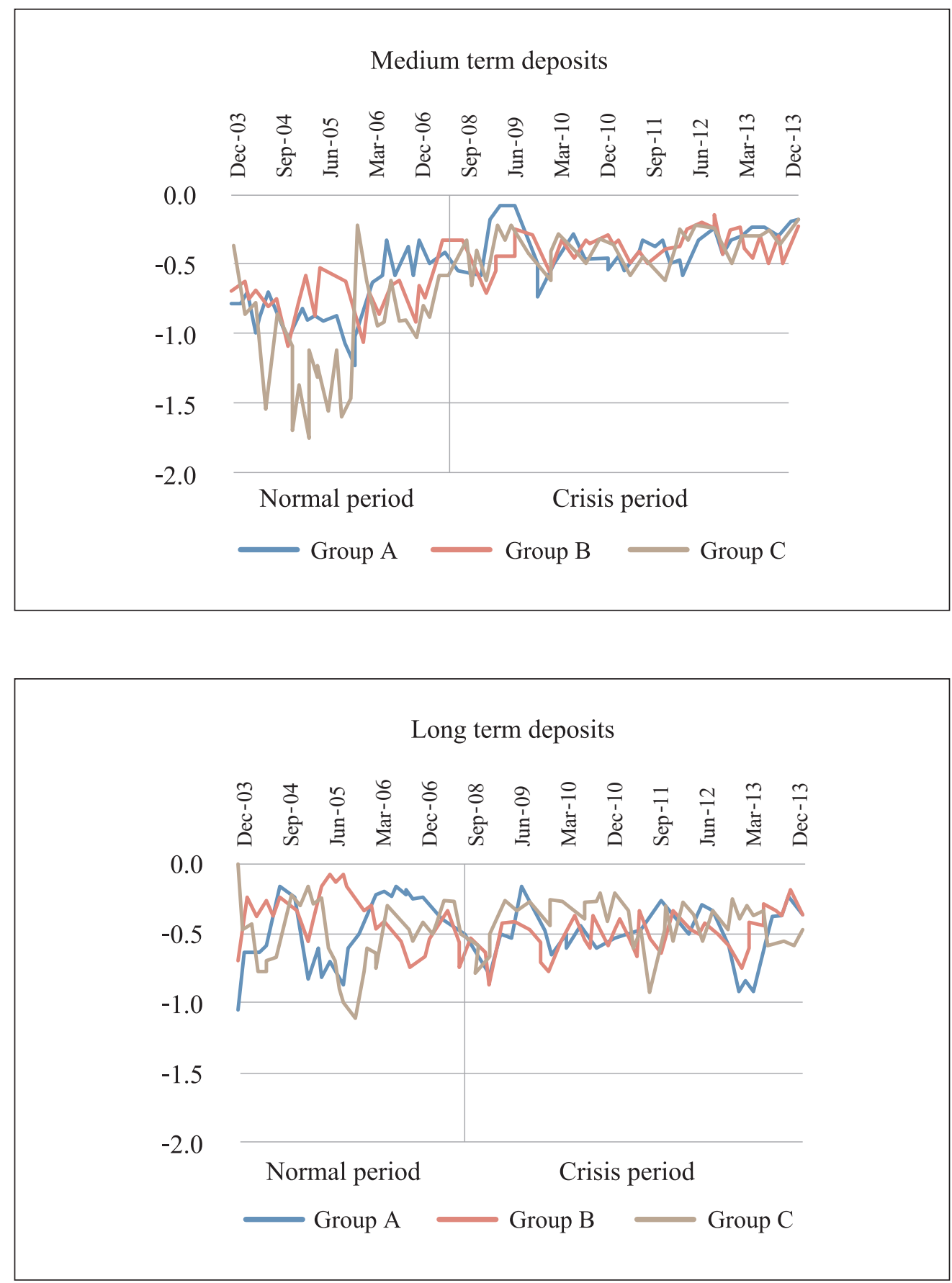

(Note) The figures display the beta convergence values for each group across the sub-periods, namely, normal period and crisis period, separately for deposit and loan products. 


\section{Deposits}

Figure 1 displays the beta convergence of short-term, medium-term, and long-term deposit rates for NFCs in Group A, Group B, and Group C, respectively.

The beta convergence results show that across the three types of maturities, the shortterm deposit rates have the strongest convergence. For medium-term deposits, Group C shows strong beta on account of Luxembourg, up to the onset of the GFC, post which, the beta values move toward zero and become negligible. The long-term deposits show weak convergence throughout the sample period. For short-term deposit rates too, the convergence weakens for all groups. A few economies in Group $\mathrm{C}$ move toward the other extreme of divergence, i.e., -2.0 . Further, for short-term rates, the convergence weakens across all countries of the sample set and most of the Group A and C economies move toward -2.0 . For medium-term rates, the convergence weakens post crisis and the beta values move toward zero. For long-term interest rates too the convergence weakens for all economies; however for Greece, Italy, Ireland, Portugal, and Spain $(\text { GIIPS })^{6}$, it moves toward the other extreme of -2.0 . France is the strongest economy in terms of convergence. Group C consists of weakly converged economies, except for Luxembourg, which shows strong convergence.

${ }^{6}$ GIIPS is used to represent the five troubled European economies i.e., Greece, Ireland, Portugal, Spain and Italy. 


\begin{tabular}{|c|c|c|c|c|c|c|c|c|c|c|c|c|c|c|}
\hline & & $\stackrel{0}{\mathscr{\omega}}$ & $\begin{array}{l}\text { Oे } \\
\stackrel{0}{0} \\
\stackrel{1}{0}\end{array}$ & $\begin{array}{l}\text { 导 } \\
\text { : }\end{array}$ & & & $\frac{0}{\infty}$ & $\begin{array}{l}n \\
\stackrel{8}{8}\end{array}$ & $\begin{array}{l}8 \\
8 \\
8\end{array}$ & & & $\frac{0}{\varpi}$ & $\begin{array}{l}0 \\
0 \\
0\end{array}$ & $\frac{\varrho}{\tilde{c}}$ \\
\hline & & $\frac{\pi}{\omega}$ & $\begin{array}{l}\overline{7} \\
\dot{0} \\
\dot{\varphi}\end{array}$ & $\begin{array}{l}\text { J } \\
\stackrel{0}{0} \\
\dot{\varphi}\end{array}$ & & & $\frac{\pi}{\mathscr{C}}$ & $\stackrel{8}{8}$ & $\begin{array}{l}\text { ¿ } \\
\stackrel{0}{0}\end{array}$ & & & $\frac{\pi}{\sigma}$ & $\stackrel{\widetilde{n}}{\stackrel{n}{0}}$ & ๙ે \\
\hline & $\begin{array}{l}u \\
=\end{array}$ & $\stackrel{\Xi}{\Xi}$ & $\begin{array}{l}\text { đ্ } \\
\text { ণ̦ }\end{array}$ & ڤ̀ & & $\begin{array}{l}U \\
=\end{array}$ & $\stackrel{y}{ٍ ~}$ & 훙 & $\stackrel{2}{8}$ & & $\begin{array}{l}U \\
=\end{array}$ & 当 & 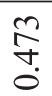 & $\begin{array}{l}0 \\
n \\
n \\
0\end{array}$ \\
\hline & $\stackrel{0}{0}$ & 方 & 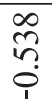 & 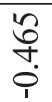 & & $\stackrel{0}{0}$ & $\bar{n}$ & $\begin{array}{l}\text { ㅇ. } \\
\stackrel{8}{\circ}\end{array}$ & $\begin{array}{l}n \\
\stackrel{8}{0}\end{array}$ & & 巳゙ & 侌 & $\stackrel{2}{\stackrel{0}{0}}$ & $\stackrel{2}{\stackrel{1}{0}}$ \\
\hline & & $\bar{\Sigma}$ & $\begin{array}{l}\text { 守 } \\
\text { me } \\
\text { p }\end{array}$ & 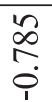 & & & $\bar{\Sigma}$ & 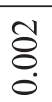 & $\stackrel{8}{8}$ & & & $\bar{\Sigma}$ & $\begin{array}{l}0 \\
\stackrel{0}{0}\end{array}$ & $\stackrel{\vec{m}}{\overrightarrow{0}}$ \\
\hline & & j & 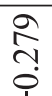 & $\stackrel{\stackrel{\Im}{\Im}}{\stackrel{f}{\circ}}$ & & & jo & $\stackrel{\circ}{\circ}$ & $\begin{array}{l}\text { ठิ } \\
\text { ¿ }\end{array}$ & & & jె & $\frac{\partial}{0}$ & $\underset{\infty}{\infty}$ \\
\hline & & $\grave{\Xi}$ & ڤn & 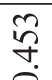 & & & $\ddot{\circ}$ & $\overline{8}$ & $\stackrel{\circ}{\circ}$ & & & $\stackrel{0}{0}$ & 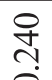 & $\stackrel{\overbrace{}}{\ddagger}$ \\
\hline & & $\stackrel{\Xi}{\Xi}$ & $\begin{array}{l}\text { Jे } \\
\text { ○े }\end{array}$ & ๙ু & & & $\stackrel{\Xi}{\Xi}$ & $\begin{array}{l}0 \\
8\end{array}$ & $\vec{\sigma}$ & & & $\stackrel{\Perp}{\Xi}$ & $\frac{\infty}{\tilde{0}}$ & กิ \\
\hline 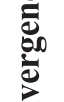 & 을 & $\stackrel{0}{0}$ & 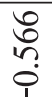 & $\begin{array}{l}\stackrel{n}{n} \\
\stackrel{f}{0} \\
\stackrel{p}{1}\end{array}$ & $\begin{array}{l}\bar{d} \\
\text { क्d } \\
\vec{z}\end{array}$ & 을 & Uِّ & 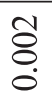 & $\stackrel{\circ}{\circ}$ & 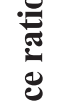 & 产 & تِّ & $\begin{array}{l}\infty \\
\stackrel{\circ}{\circ} \\
\stackrel{n}{0}\end{array}$ & ๙ุ \\
\hline 馬 & & 江 & $\frac{\stackrel{8}{2}}{0}$ & م̂̊? & $\begin{array}{l}\text { 巳 } \\
\text { : }\end{array}$ & & $\Xi$ & $\underset{8}{\overrightarrow{8}}$ & $\begin{array}{l}\mathscr{8} \\
\stackrel{8}{0}\end{array}$ & స్ & & 陦 & $\stackrel{\infty}{\stackrel{\infty}{+}}$ & $\begin{array}{l}\bar{\infty} \\
\stackrel{0}{0}\end{array}$ \\
\hline $\begin{array}{l}\ddot{\varphi} \\
\ddot{u}\end{array}$ & & $\stackrel{\varrho}{\Xi}$ & $\frac{N}{\stackrel{N}{0}}$ & 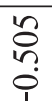 & $\ddot{\theta}$ & & $\stackrel{\varrho}{\varkappa}$ & $\stackrel{\overrightarrow{8}}{\circ}$ & $\stackrel{8}{8}$ & $\underset{\ddot{g}}{\ddot{\Xi}}$ & & $\stackrel{\varrho}{E}$ & $\underset{0}{\vec{J}}$ & ঙ্গি \\
\hline 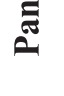 & & हี & $\stackrel{ \pm}{\underset{0}{0}}$ & 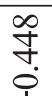 & $\stackrel{\Xi}{\Xi}$ & & $\overline{\bar{n}}$ & 훙. & $\begin{array}{l}8 \\
8 \\
8\end{array}$ & 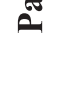 & & क्ञ & $\stackrel{\vartheta}{\stackrel{\nabla}{\sigma}}$ & $\stackrel{m}{\underset{\sigma}{\sigma}}$ \\
\hline & & $\stackrel{\overline{0}}{Z}$ & $\stackrel{\text { กี }}{=}$ & $\begin{array}{l}\bar{\sigma} \\
\stackrel{0}{0}\end{array}$ & & & ¿ & $\overline{8}$ & $\stackrel{n}{\circ}$ & & & $\ddot{z}$ & $\begin{array}{l}\infty \\
n \\
n \\
0\end{array}$ & \begin{tabular}{l}
0 \\
\multirow{0}{*}{}
\end{tabular} \\
\hline & $\stackrel{2}{2}$ & $\stackrel{\Xi}{\Xi}$ & 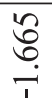 & مू & & $\begin{array}{l}\longleftarrow \\
=\end{array}$ & $\stackrel{\Xi}{=}$ & $\begin{array}{l}\overline{8} \\
\end{array}$ & 용 & & $\begin{array}{l}\Psi \\
\cong\end{array}$ & $\stackrel{\Xi}{\Xi}$ & กี & $\frac{a}{n}$ \\
\hline & ป๋ & $\grave{\Xi}$ & $\stackrel{2}{=}$ & 守 & & อ̆丶 & ذ্் & \begin{tabular}{l}
8 \\
8 \\
\hdashline
\end{tabular} & $\stackrel{n}{8}$ & & 党 & ت্் & $\begin{array}{l}\mathscr{2} \\
\stackrel{0}{0} \\
0\end{array}$ & $\begin{array}{l}\overline{\text { లె }} \\
0\end{array}$ \\
\hline & & $\underset{\nu}{己}$ & 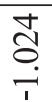 & $\begin{array}{l}\text { 我 } \\
\stackrel{+}{+}\end{array}$ & & & 茓 & $\begin{array}{l}8 \\
8 \\
8\end{array}$ & ठ̊. & & & 苋 & $\stackrel{n}{n}$ & $\underset{?}{\tilde{J}}$ \\
\hline & & $\bar{\Phi}$ & $\begin{array}{l}\hat{n} \\
\stackrel{5}{0}\end{array}$ & $\begin{array}{l}\stackrel{+}{n} \\
n \\
0\end{array}$ & & & $\bar{\oplus}$ & $\begin{array}{l}\overrightarrow{8} \\
\end{array}$ & $\begin{array}{l}8 \\
8 \\
8 \\
0\end{array}$ & & & $\bar{\oplus}$ & $\stackrel{\vec{n}}{\stackrel{5}{0}}$ & 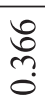 \\
\hline & & & 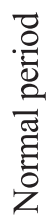 & 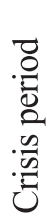 & & & & 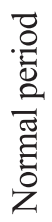 & 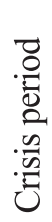 & & & & 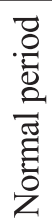 & 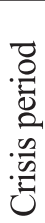 \\
\hline
\end{tabular}




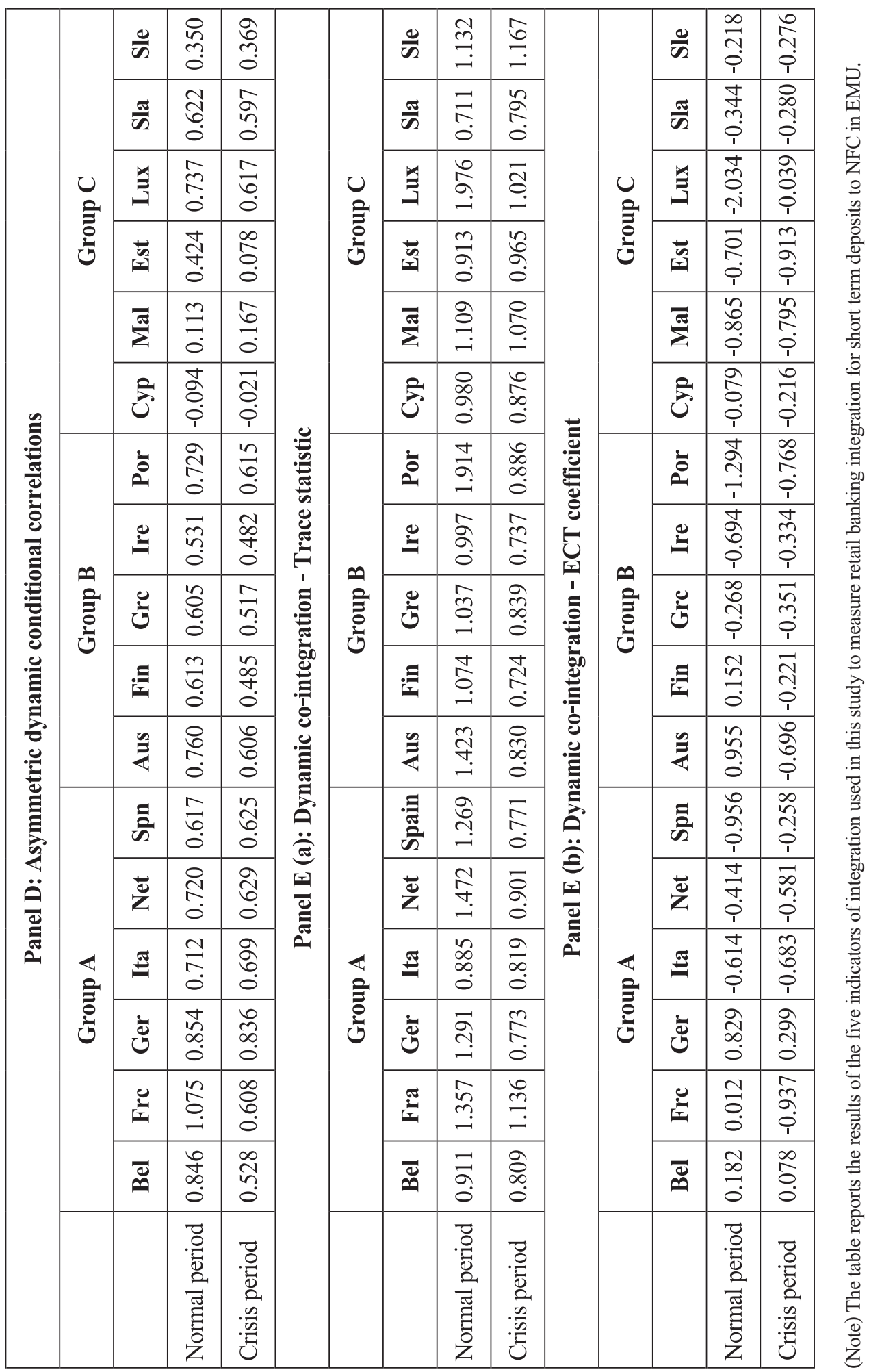


Figure 2. Beta convergence of loans
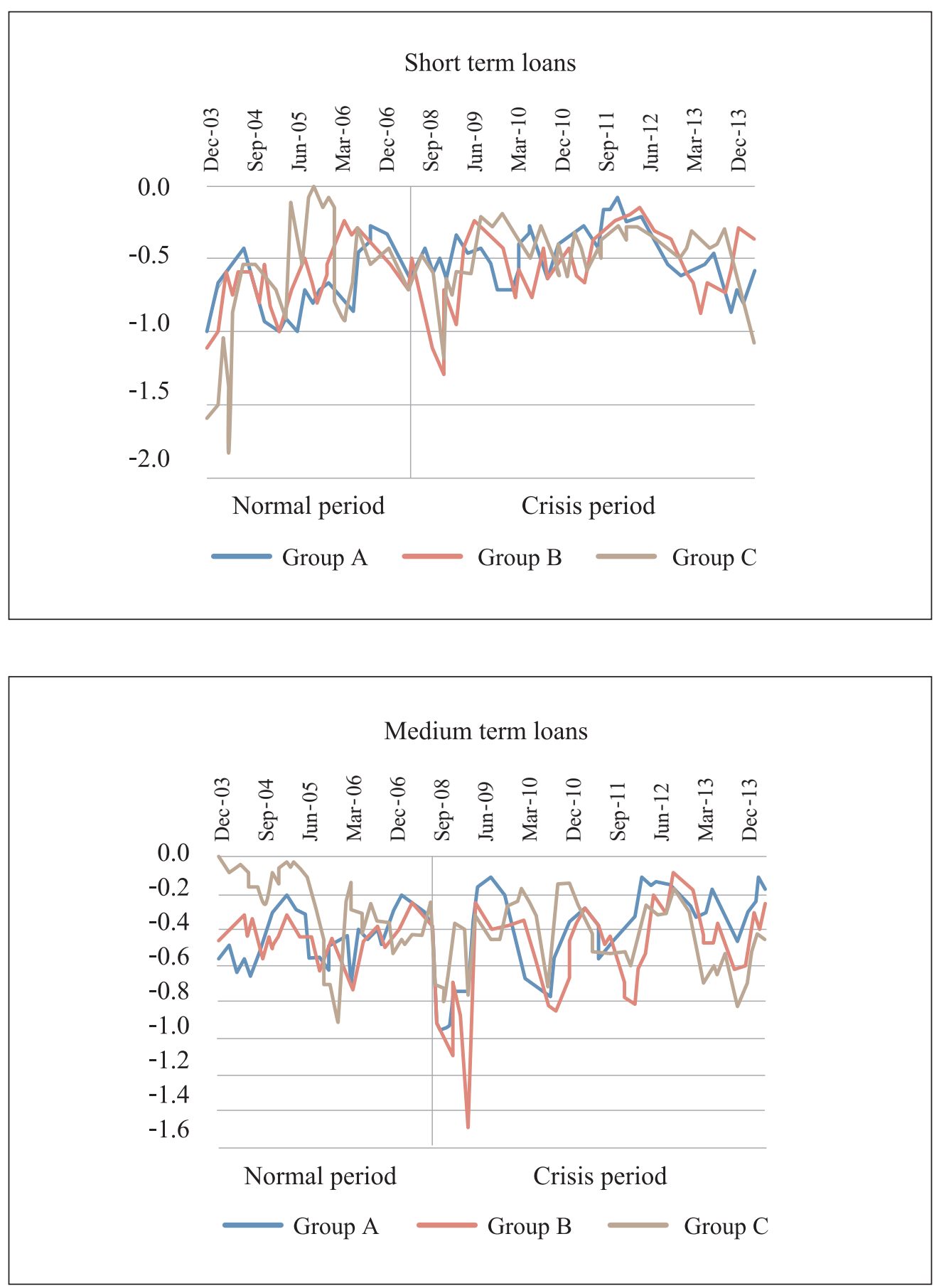


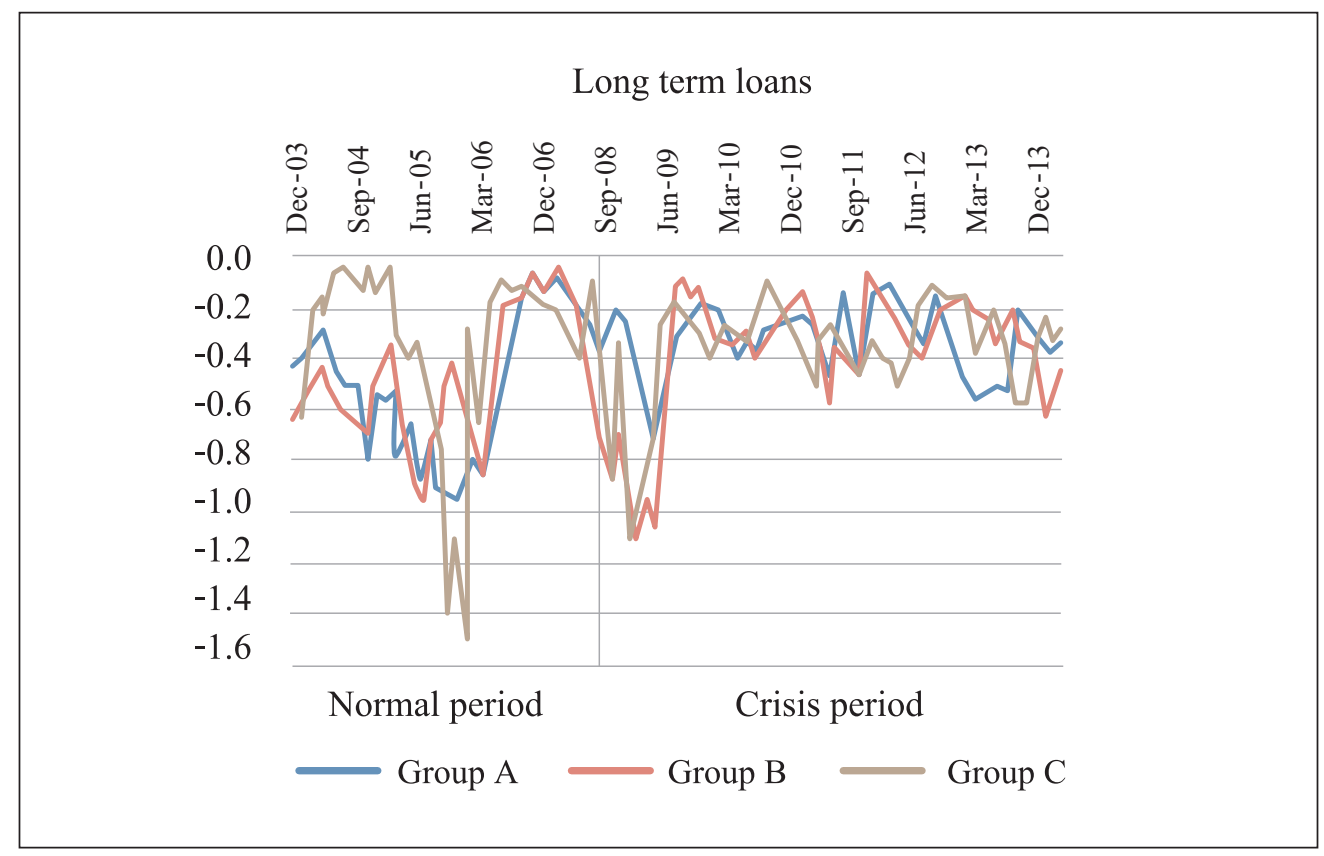

(Note) The figure displays the beta convergence values for each group across the sub-periods, namely, normal period and crisis period for loan products.

\section{Loans}

Figure 2 displays the beta convergence for short-term, medium-term, and long-term loan rates for Group A, Group B, and Group C, respectively. From the beta convergence results for loans to NFCs, we see that overall, the convergence is weak for all maturities. Across maturities, the economies display signs of relatively stronger convergence during the period after the onset of the GFC up to the onset of the EDC. This may point toward contagion as pessimism gripped the union. For all maturities, Group B displays stronger convergence than Group A and Group C; however, there are no stark differences across the groups. Again, France is a strongly converged economy across all maturities. However, for loans, unlike deposits, Luxembourg does not show strong convergence. Overall, we observe that the deposit rates show relatively stronger convergence than the loan rates. 


\section{B. Sigma convergence}

Figure 3. Sigma convergence of deposits
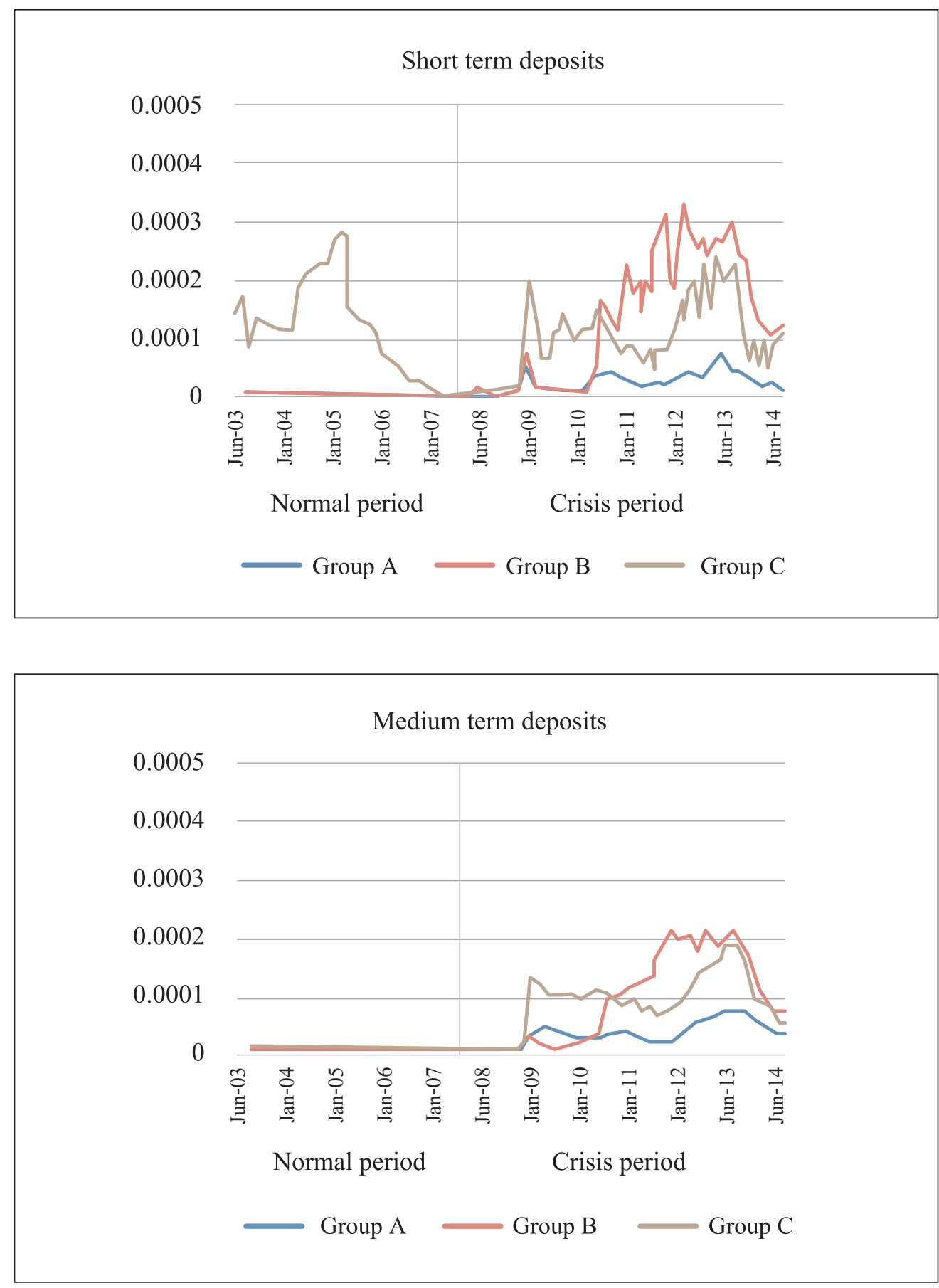


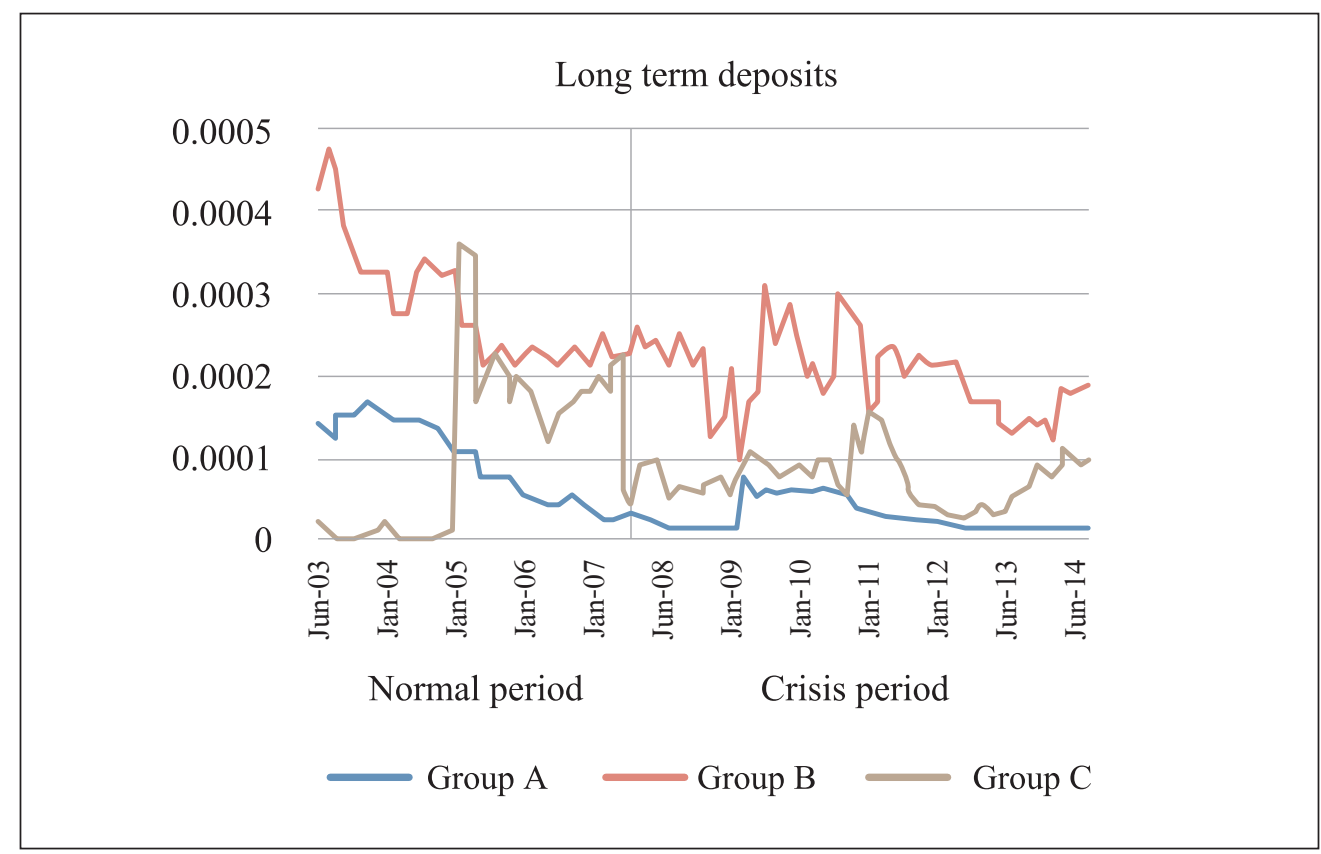

(Note) The figures display the sigma convergence values for each group across the sub-periods, namely, normal period and crisis period, separately for deposit and loan products.

\section{Deposits}

The results of sigma convergence allow us to conclude that the long-term interest rates show the highest dispersion as compared with the other maturities. Figure 3 displays the sigma convergence for short-term, medium-term, and long-term deposit rates for Group A, Group B, and Group C, respectively. The long-term interest rates were dispersed even during the Normal period. On the other hand, for all economies, the medium-term and short-term interest rates (except Group C) showed negligible dispersion. However, these short-term and medium-term interest rates also exhibited a steep rise in dispersion from the onset of EDC. Cross-sectional dispersion is the highest in case of Group B across all maturities, followed by Group C. Group A showed the least dispersion. The average values show that for short- and medium-term maturities, there is an increase in dispersion from the third quarter of 2008. The dispersion displayed by long-term maturities also increased during this period; however, it declined from second quarter of 2011 onwards, to even below the average dispersion shown during Normal period which can be attributed to the optimism created by the introduction of the European Stability Mechanism and the bailout of Portugal, Italy and Greece in May 2011. 


\begin{tabular}{|c|c|c|c|c|c|c|c|c|c|c|c|c|c|c|}
\hline & & $\frac{\ddot{n}}{\sigma}$ & 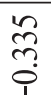 & 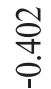 & & & $\frac{\ddot{\sigma}}{\sigma}$ & $\stackrel{8}{8}$ & 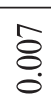 & & & $\frac{\ddot{n}}{\sim}$ & ֶె & $\stackrel{\circ}{\stackrel{0}{1}}$ \\
\hline & & $\frac{\pi}{\sigma}$ & $\frac{\text { I }}{7}$ & $\stackrel{m}{\vec{\sigma}}$ & & & $\frac{\pi}{\sigma}$ & ठ̊. & $\stackrel{\infty}{8}$ & & & $\frac{\pi}{\sigma}$ & ?ूे & $\stackrel{ }{\Xi}$ \\
\hline & $\begin{array}{l}u \\
=\end{array}$ & 气 & $\frac{\widetilde{n}}{7}$ & $\begin{array}{l}\hat{\alpha} \\
\text { +. } \\
\text { }\end{array}$ & & $\begin{array}{l}0 \\
=\end{array}$ & 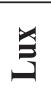 & $\overline{8}$ & $\stackrel{8}{8}$ & & $\begin{array}{l}U \\
\Xi\end{array}$ & 气 & $\tilde{n}$ & 음 \\
\hline & 比 & 氞 & $\begin{array}{l}n \\
n \\
n \\
?\end{array}$ & $\begin{array}{l}\tilde{n} \\
\text { ?े }\end{array}$ & & อे & 氛 & 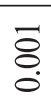 & ஜ & & 党 & 侌 & $\begin{array}{l}0 \\
8 \\
0 \\
0\end{array}$ & ֶి \\
\hline & & $\bar{\Sigma}$ & $\begin{array}{l}\text { o } \\
\text { m? } \\
\text { ? }\end{array}$ & $\begin{array}{l}\text { ț } \\
\text { +. } \\
\text { i }\end{array}$ & & & $\bar{\Sigma}$ & 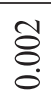 & है & & & $\bar{\Sigma}$ & 8 & $\begin{array}{l}\infty \\
\infty \\
0\end{array}$ \\
\hline & & jె & $\vec{m}$ & $\frac{\infty}{0}$ & & & s & $\bar{\sigma}$ & $\stackrel{\infty}{\circ}$ & & & 己े & $\stackrel{1}{\infty}$ & $\stackrel{m}{=}$ \\
\hline & & $\ddot{\partial}$ & $\frac{n}{\stackrel{5}{+}}$ & $\begin{array}{l}\stackrel{+}{+} \\
\stackrel{+}{+}\end{array}$ & & & $\dot{\overline{0}}$ & है & \&े & & & $\ddot{\grave{a}}$ & 匍 & 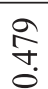 \\
\hline & & $\stackrel{\Xi}{\Xi}$ & $\frac{\pi}{\hat{O}}$ & $\begin{array}{l}\text { तु } \\
\text { nె } \\
\text { ?े }\end{array}$ & & & $\stackrel{\Xi}{ }$ & \&. & ஜ̊ & & & 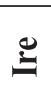 & ? & ?ొ \\
\hline 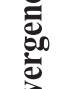 & $\bar{\Xi}$ & Jँّ & ర్ర & ते & 㺃 & 言 & U⿺尢丶 & \&े & $\stackrel{ }{\circ}$ & 尊 & $\bar{\Xi}$ & تِّ & $\begin{array}{l}n \\
\infty \\
0 \\
0\end{array}$ & $\begin{array}{l}\infty \\
\stackrel{\overbrace{}}{0}\end{array}$ \\
\hline 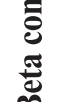 & & 江 & $\begin{array}{l}\underset{+}{+} \\
\stackrel{\infty}{+}\end{array}$ & $\begin{array}{l}\hat{n} \\
\stackrel{n}{\varphi}\end{array}$ & 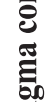 & & 的 & हे & ஜे & 荬 & & 江 & $\begin{array}{l}\text { t: } \\
0 \\
0\end{array}$ & 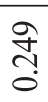 \\
\hline$\underset{\dot{\Xi}}{\ddot{\Xi}}$ & & $\stackrel{\varrho}{z}$ & 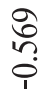 & 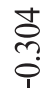 & $\ddot{\theta}$ & & $\stackrel{\varrho}{E}$ & ठ̊. & $\stackrel{8}{8}$ & $\frac{U}{\mathbb{\Xi}}$ & & $\stackrel{\varrho}{\gtrless}$ & $\begin{array}{l}\text { 盛 } \\
0\end{array}$ & $\stackrel{\circ}{\stackrel{5}{0}}$ \\
\hline ค & & के & $\stackrel{\infty}{\infty}$ & $\hat{\overbrace{}}$ & 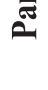 & & के & రి & \&. & & & ڤี & \begin{tabular}{l}
8 \\
o \\
\multirow{0}{0}{}
\end{tabular} & $\underset{\widehat{~}}{\tilde{\sigma}}$ \\
\hline & & 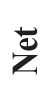 & 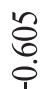 & స్త & & & ¿ँ & ఠ̊ & \&̊. & & & ¿ँ & $\begin{array}{l}n \\
n \\
n \\
0\end{array}$ & $\begin{array}{l}\text { †े } \\
\stackrel{0}{0}\end{array}$ \\
\hline & $\underset{Z}{Z}$ & $\stackrel{\Xi}{=}$ & $\underset{\mathbf{0}}{\stackrel{0}{0}}$ & 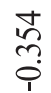 & & 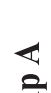 & $\Xi$ & 용 & ') & & 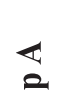 & $\stackrel{\Xi}{=}$ & ఫ్రి & $\begin{array}{l}8 \\
\text { ? } \\
0\end{array}$ \\
\hline & 包 & ت் & 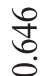 & $\frac{\sigma}{\sigma}$ & & ํㅣㄴ & تٓ & 8 & 용. & & 은 & $\dot{\bar{\varpi}}$ & $\stackrel{N}{n}$ & ஓे \\
\hline & & ِّ & $\begin{array}{l}\infty \\
\infty \\
\infty \\
0\end{array}$ & $\underset{0}{\infty}$ & & & Dِ & @ి & $\stackrel{\text { }}{8}$ & & & 苂 & $\overrightarrow{\widehat{े}}$ & $\stackrel{\sim}{\tilde{n}}$ \\
\hline & & $\bar{D}$ & $\begin{array}{l}\text { oे } \\
\text { n़่ }\end{array}$ & $\begin{array}{l}\stackrel{n}{r} \\
\stackrel{5}{0}\end{array}$ & & & $\bar{\oplus}$ & Бे & \&̊. & & & $\bar{D}$ & ñ & 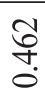 \\
\hline & & & 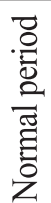 & $\begin{array}{l}\overrightarrow{0} \\
.0 \\
0 \\
0 \\
.00 \\
0\end{array}$ & & & & 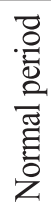 & 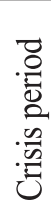 & & & & 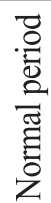 & 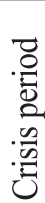 \\
\hline
\end{tabular}




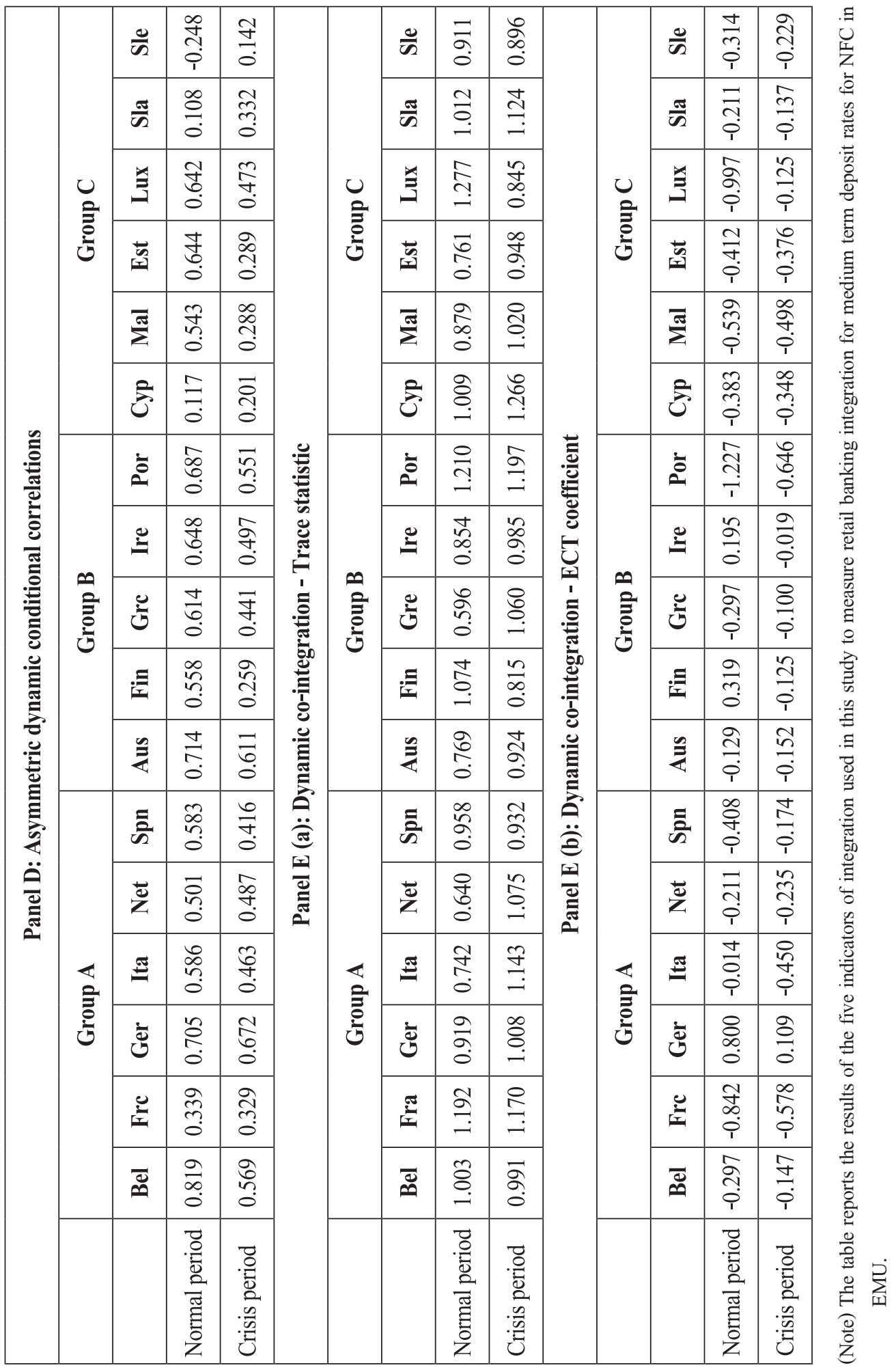




\section{Figure 4. Sigma convergence of loans}
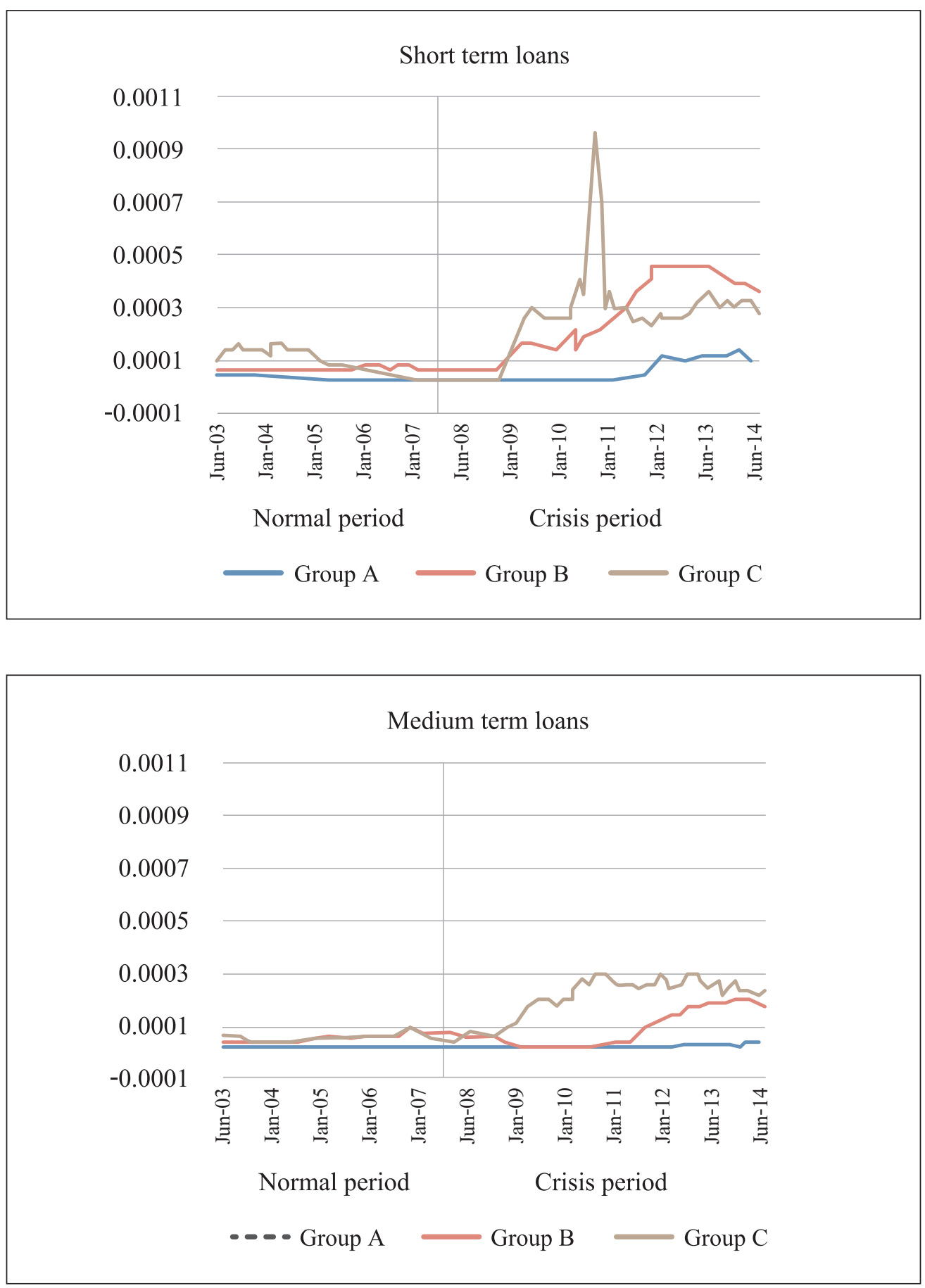


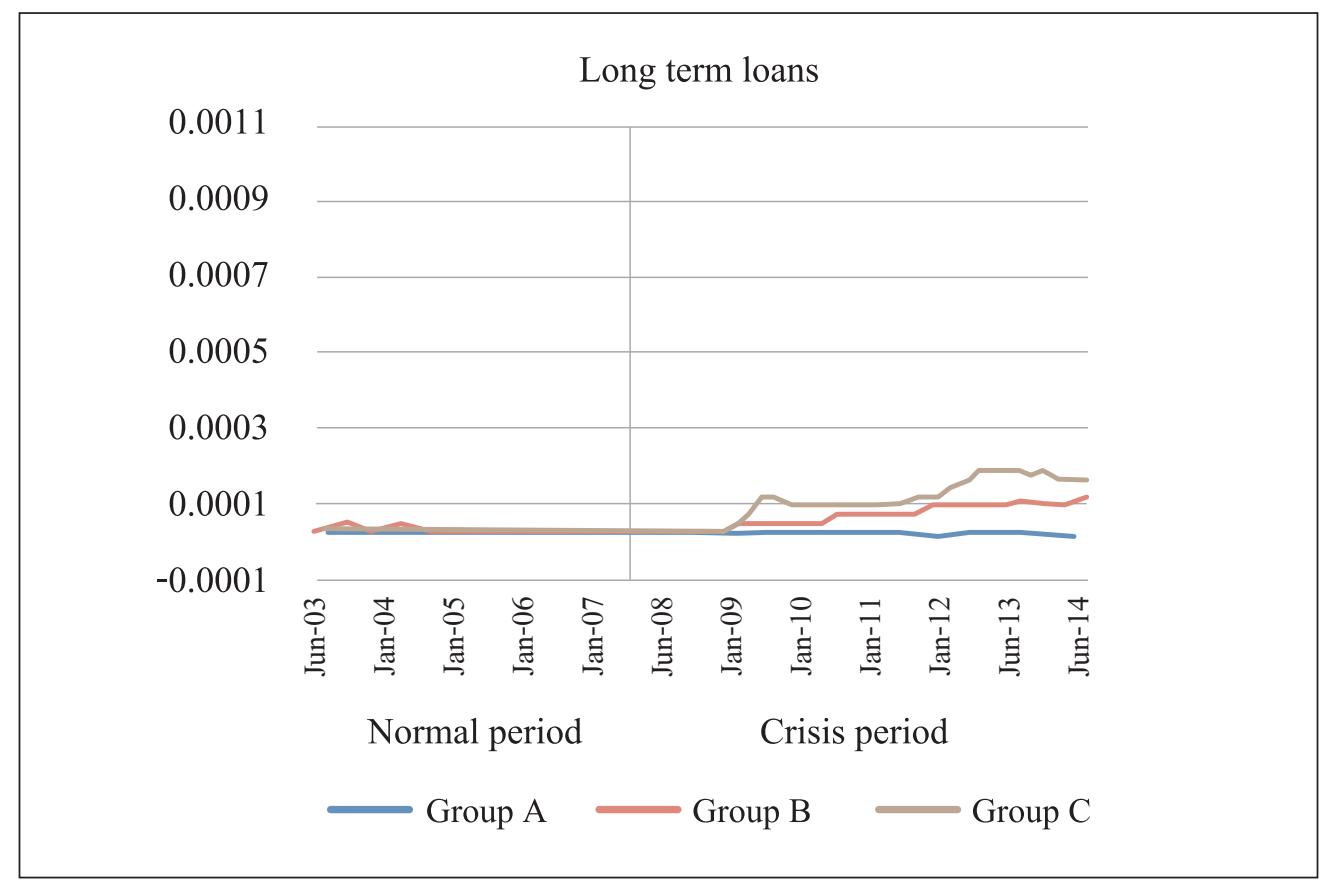

(Note) The figure displays the sigma convergence values for each group across the sub-periods, namely, normal period and crisis period for loan products.

\section{Loans}

Figure 4 displays the sigma convergence for short-, medium-, and long-term loan rates to NFCs for Group A, Group B, and Group C, respectively. For loans, the results show that the loans data showed higher dispersion as compared with the deposits data. Especially during the Crisis period, there was a steep increase in dispersion as displayed by Group B and Group C economies for short-term credit rates. For medium-term rates too, Group B and Group C economies show an increase in dispersion. The long-term rates were the least affected by the crisis. Across all maturities, Group A shows the least dispersion during both crisis and Normal periods, while Group C shows the highest dispersion. 


\section{Variance ratio}

Figure 5. Variance ratio of deposits
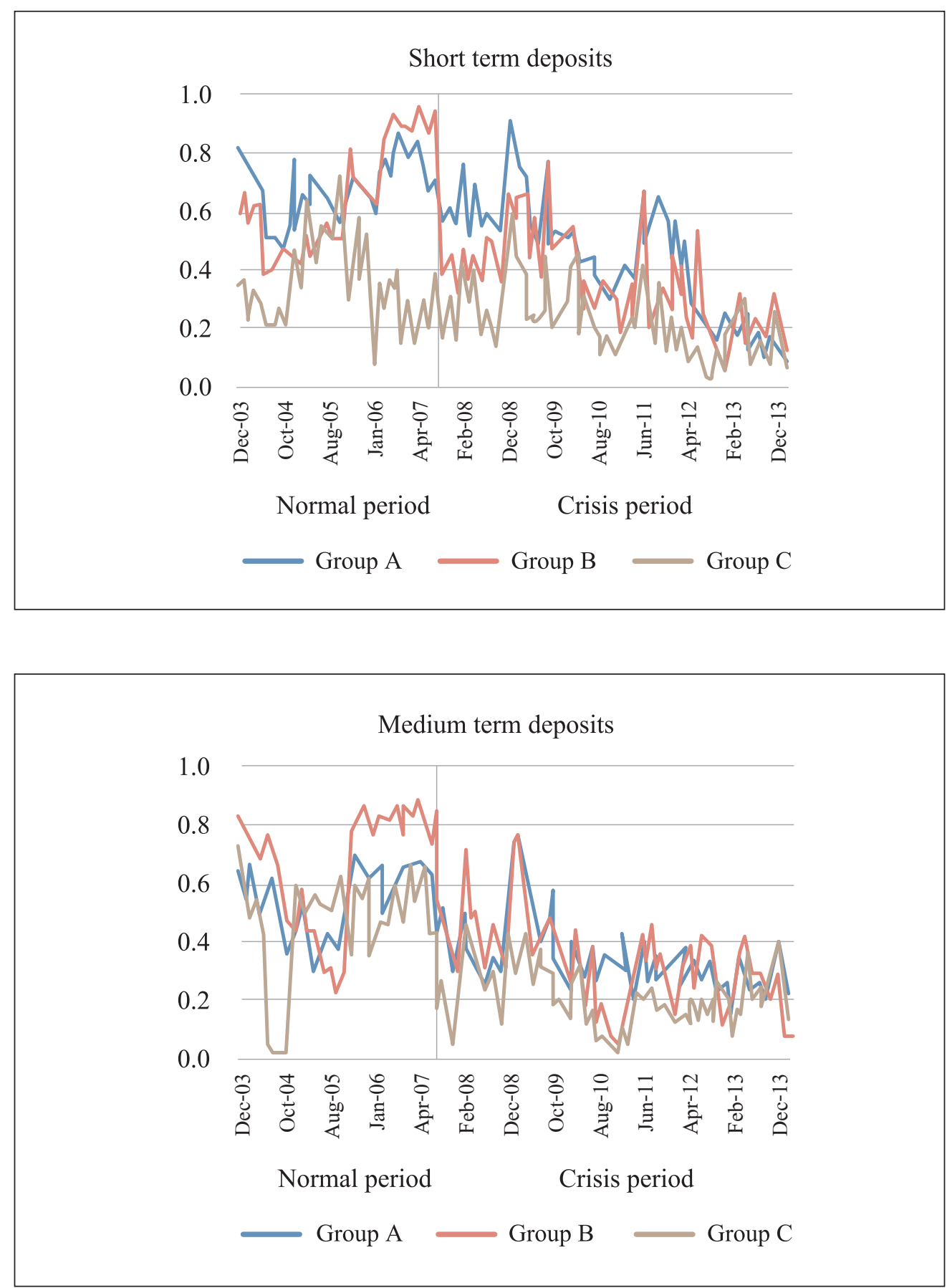


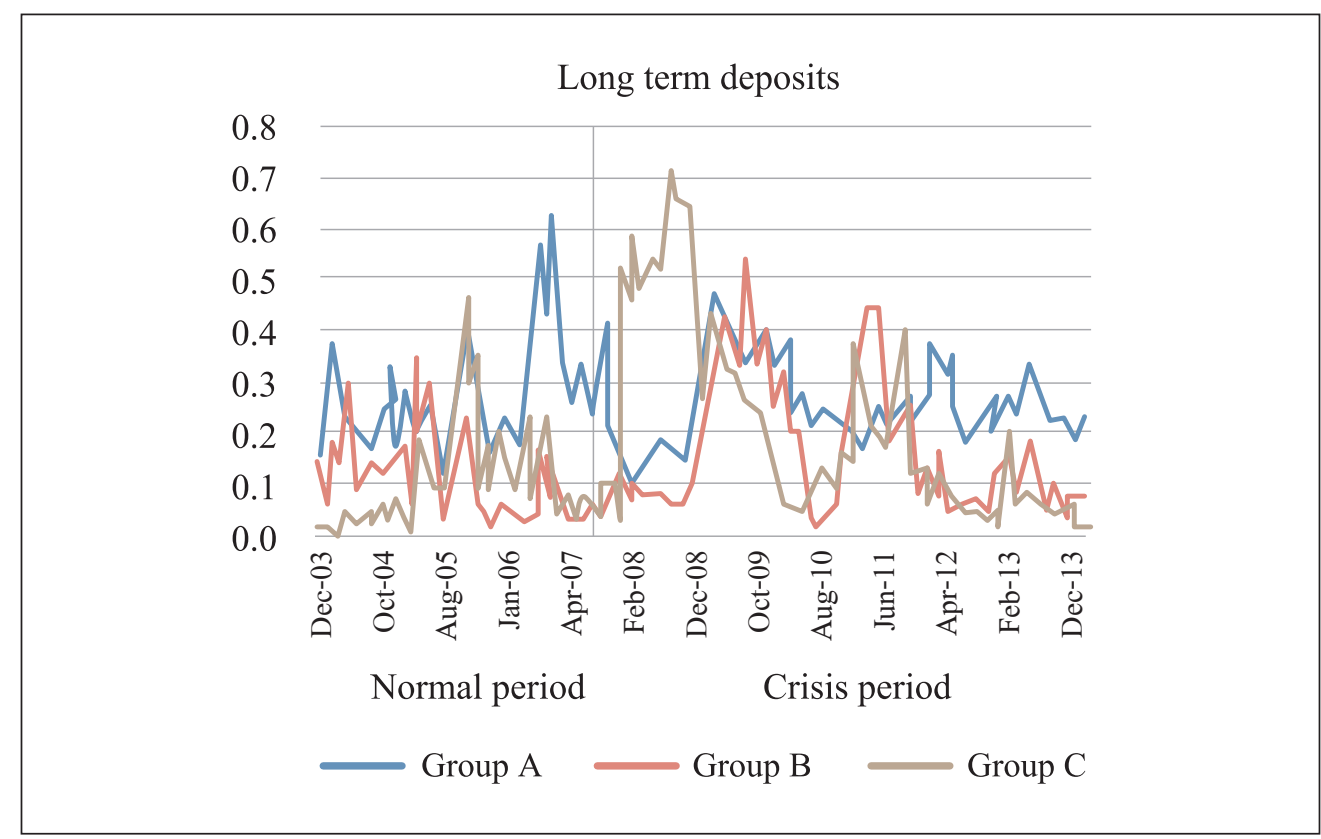

(Note) The figures display variance ratio for each group across the sub-periods, namely, normal period and crisis period, separately for deposit and loan products.

\section{Deposits}

The variance ratio analysis for the deposit rates shows that across the three maturities, short-term rates show the highest degree of integration, closely followed by medium-term deposits. Figure 3 displays the results for variance ratios for the shortterm, medium-term, and long-term deposit rates for Group A, Group B, and Group C, respectively. However, the long-term deposit rates show almost negligible integration. In case of short-term and medium-term deposits, during the Normal period, Group B takes the lead. Group A also shows a similar degree of integration. In the case of long-term deposits, the interest rates of Group A economies display relatively higher integration except during the GFC (2007 to 2008), when the variance in interest rates of Group C was strongly driven by the EMU variance. Otherwise, for all the maturities, throughout the sample period, Group C economies display the lowest degree of integration. We see that for short-term and medium-term deposit rates, all the groups experience a setback in integration as the Variance ratio falls across all the economies. For Group A, France shows the highest integration for long-term maturities, while Germany has the highest Variance ratio for short- and medium-term deposits. In the case of Group B and Group C economies, Austria and Luxembourg display the highest integration across all maturities throughout the sample period. 


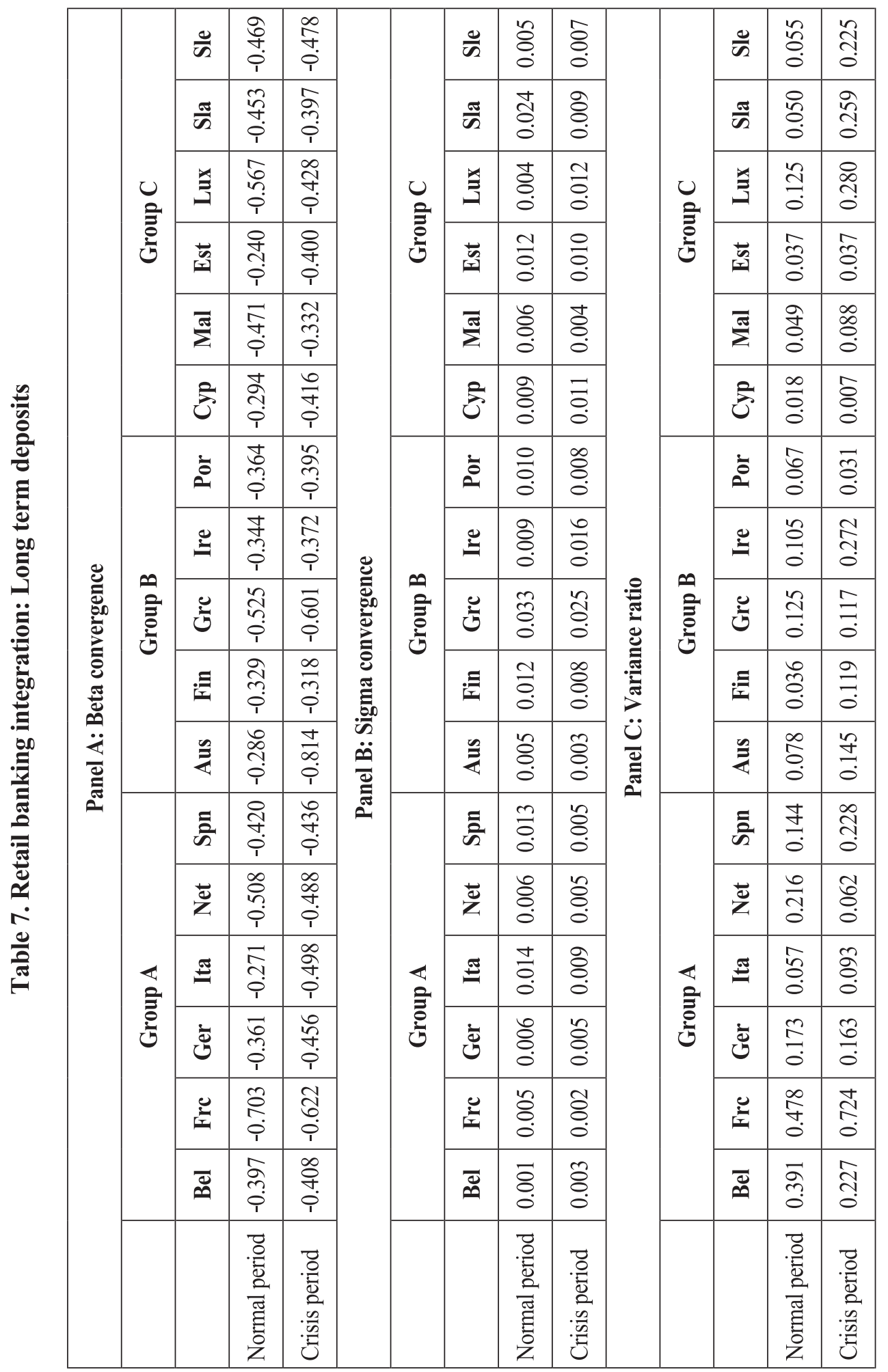




\begin{tabular}{|c|c|c|c|c|c|c|c|c|c|c|c|c|c|c|}
\hline \multirow{6}{*}{\multicolumn{2}{|c|}{ 气̊ํㅡㄹ }} & $\frac{\varrho}{\sigma}$ & $\begin{array}{l}\infty \\
\text { ஸे } \\
\text { }\end{array}$ & $\begin{array}{l}\text { oे } \\
\text { กิ }\end{array}$ & \multirow{18}{*}{ 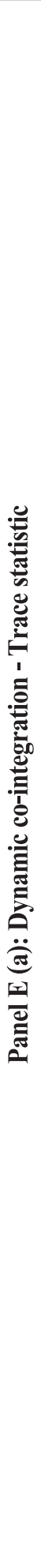 } & \multirow{6}{*}{ 苞 } & $\frac{\ddot{\sigma}}{\mathscr{a}}$ & $\bar{\sigma}$ & $\begin{array}{l}\approx \\
\infty \\
\infty \\
0\end{array}$ & & \multirow{6}{*}{ 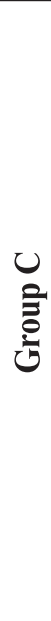 } & $\frac{\ddot{\sigma}}{\mathscr{a}}$ & $\begin{array}{l}\stackrel{ \pm}{\Xi} \\
\stackrel{1}{9}\end{array}$ & 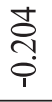 \\
\hline & & $\frac{\widetilde{H}}{\widetilde{\sigma}}$ & $\overline{8}$ & $\frac{0}{3}$ & & & क्ष & $\begin{array}{l}\text { हై } \\
0\end{array}$ & 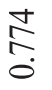 & & & $\frac{\pi}{\widetilde{\sigma}}$ & $\frac{\vec{\Xi}}{\dot{0}}$ & $\begin{array}{l}\frac{d}{0} \\
\stackrel{0}{c}\end{array}$ \\
\hline & & $\stackrel{\Xi}{\Xi}$ & $\begin{array}{l}\text { ֻे } \\
\text { ஸे }\end{array}$ & $\stackrel{\circ}{\stackrel{0}{d}}$ & & & 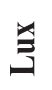 & 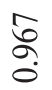 & $\frac{2}{\stackrel{2}{0}}$ & & & $\stackrel{\Perp}{\Xi}$ & $\begin{array}{l}\tilde{n} \\
\tilde{n} \\
i\end{array}$ & $\frac{m}{\tilde{n}}$ \\
\hline & & 荃 & $\frac{\dddot{M}}{\stackrel{9}{p}}$ & $\begin{array}{l}\text { षे } \\
\text { : }\end{array}$ & & & 蒙 & $\stackrel{\tilde{\sigma}}{\tilde{\sigma}}$ & త్రి & & & 氛 & 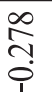 & 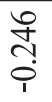 \\
\hline & & $\bar{\Sigma}$ & $\frac{\hat{n}}{0}$ & $\stackrel{2}{\circ}$ & & & $\sum^{\bar{\sigma}}$ & $\underset{\frac{m}{\infty}}{\infty}$ & $\frac{\tilde{\sigma}}{2}$ & & & $\sum^{\bar{\sigma}}$ & $\frac{\mathscr{\infty}}{\overrightarrow{0}}$ & $\frac{\mathbb{J}}{\dot{0}}$ \\
\hline & & 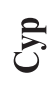 & $\frac{\infty}{\stackrel{\infty}{0}}$ & 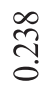 & & & క & 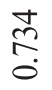 & $\frac{m}{a}$ & & & 3 & $\begin{array}{l}\text { ô } \\
\text { : } \\
\end{array}$ & $\begin{array}{l}\stackrel{n}{0} \\
\stackrel{0}{1}\end{array}$ \\
\hline \multirow{12}{*}{ 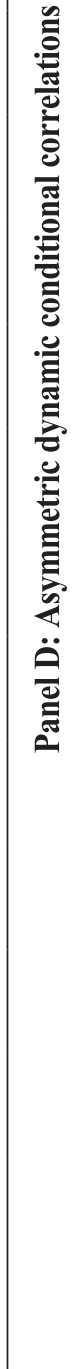 } & \multirow{5}{*}{ 电 } & $\ddot{0}$ & ণิ స్ & 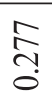 & & & 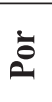 & $\widehat{\widehat{\sigma}}$ & $\begin{array}{l}n \\
\stackrel{2}{0} \\
\stackrel{-}{0}\end{array}$ & 氬 & \multirow{5}{*}{ 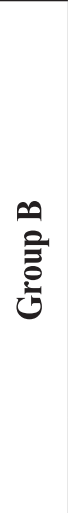 } & $\dot{\vec{a}}$ & $\frac{ \pm}{\stackrel{ \pm}{9}}$ & 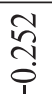 \\
\hline & & $\stackrel{\circlearrowright}{\Xi}$ & \%ి. & $\frac{\sigma}{n}$ & & & $\stackrel{\Xi}{\Xi}$ & $\frac{\stackrel{F}{\leftarrow}}{\circ}$ & $\begin{array}{l}\stackrel{\circ}{\circ} \\
\text { }\end{array}$ & 己 & & $\stackrel{\Xi}{\Xi}$ & $\frac{n}{\stackrel{0}{0}}$ & $\begin{array}{l}\underset{\sim}{\mathbb{N}} \\
\stackrel{i}{+}\end{array}$ \\
\hline & & Uై & $\frac{\mathscr{J}}{0}$ & $\begin{array}{l}\bar{\sigma} \\
\overrightarrow{0}\end{array}$ & & 三 & Jँّ & $\begin{array}{l}2 \\
2 \\
0 \\
0\end{array}$ & $\stackrel{\Xi}{\underline{0}}$ & 竞 & & Uై & $\begin{array}{l}\text { ஜे } \\
\text { ஓे } \\
\text { 1. }\end{array}$ & $\begin{array}{l}\text { مे } \\
\text { ?ె? } \\
\text { i }\end{array}$ \\
\hline & & 注 & $\frac{0}{0}$ & $\frac{n}{0}$ & & & 江 & $\begin{array}{l}\stackrel{0}{n} \\
\stackrel{0}{0}\end{array}$ & $\frac{n}{a}$ & 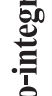 & & 注 & $\begin{array}{l}\text { ¿ै } \\
\text { Oे. } \\
\stackrel{0}{0}\end{array}$ & $\frac{n}{\frac{1}{\rho}}$ \\
\hline & & $\stackrel{\varrho}{\xi}$ & है. & ঐे & & & $\stackrel{\varrho}{\gtrless}$ & $\stackrel{2}{\circ}$ & $\stackrel{\vec{\sigma}}{\sigma}$ & 异 & & $\stackrel{\varrho}{E}$ & 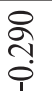 & $\begin{array}{l}\hat{\sigma} \\
\text { ஸे } \\
\hat{1}\end{array}$ \\
\hline & \multirow{6}{*}{ 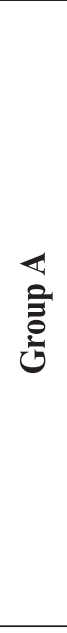 } & क्ञ & $\frac{\infty}{\tilde{\sigma}}$ & $\begin{array}{l}\infty \\
\text { @ె } \\
0\end{array}$ & & & 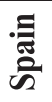 & $\begin{array}{l}\bar{\sigma} \\
\stackrel{\sigma}{0}\end{array}$ & $\begin{array}{l}\qquad \\
2 \\
\infty \\
0\end{array}$ & $\begin{array}{c}\hat{\vec{\theta}} \\
\ddot{\hat{\theta}}\end{array}$ & & ڤँ & 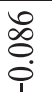 & $\frac{\infty}{\stackrel{\infty}{0}}$ \\
\hline & & ¿ँ & $\begin{array}{l}\text { rె } \\
\text { ్} \\
0\end{array}$ & 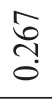 & & & 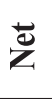 & 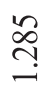 & ఫ্ర & 可 & & 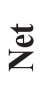 & ৫్రి & 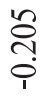 \\
\hline & & $\stackrel{\Xi}{\Xi}$ & $\frac{\mathscr{I}}{7}$ & $\frac{\text { I }}{0}$ & & 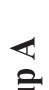 & $\stackrel{\Xi}{ \pm}$ & $\begin{array}{l}\mathbb{d} \\
\stackrel{0}{0}\end{array}$ & $\hat{\sigma}$ & & 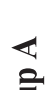 & $\Xi$ & $\stackrel{\infty}{\circ}$ & 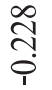 \\
\hline & & ن் & $\begin{array}{l}\overline{0} \\
\text { ?ై }\end{array}$ & $\begin{array}{c}\text { Dै } \\
\text { ?ై }\end{array}$ & & ํํㄴ & ¿் & 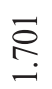 & કั & & $\stackrel{\ominus}{U}$ & シ் & 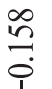 & $\begin{array}{l}\stackrel{1}{n} \\
\text { ก̦ }\end{array}$ \\
\hline & & ְِ & $\underset{ర}{\mathbb{\sigma}}$ & 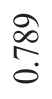 & & & 蛋 & f̊ & $\begin{array}{l}\stackrel{8}{\circ} \\
\stackrel{0}{0}\end{array}$ & & & 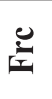 & $\begin{array}{l}\text { 寺 } \\
\overrightarrow{9}\end{array}$ & $\begin{array}{l}\text { ֻิ } \\
\text { ஸे }\end{array}$ \\
\hline & & $\bar{\Phi}$ & $\stackrel{2}{\dddot{0}}$ & $\frac{\infty}{\overrightarrow{0}}$ & & & $\bar{\oplus}$ & $\begin{array}{l}\tilde{\tilde{D}} \\
\hat{0} \\
0\end{array}$ & है & & & $\bar{\oplus}$ & $\begin{array}{l}20 \\
\frac{\infty}{9}\end{array}$ & 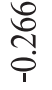 \\
\hline & & & 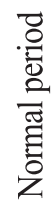 & 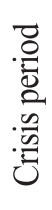 & & & & 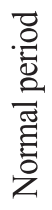 & 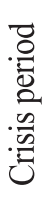 & & & & 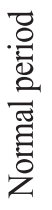 & 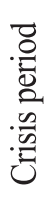 \\
\hline
\end{tabular}


Figure 6. Variance ratio of loans

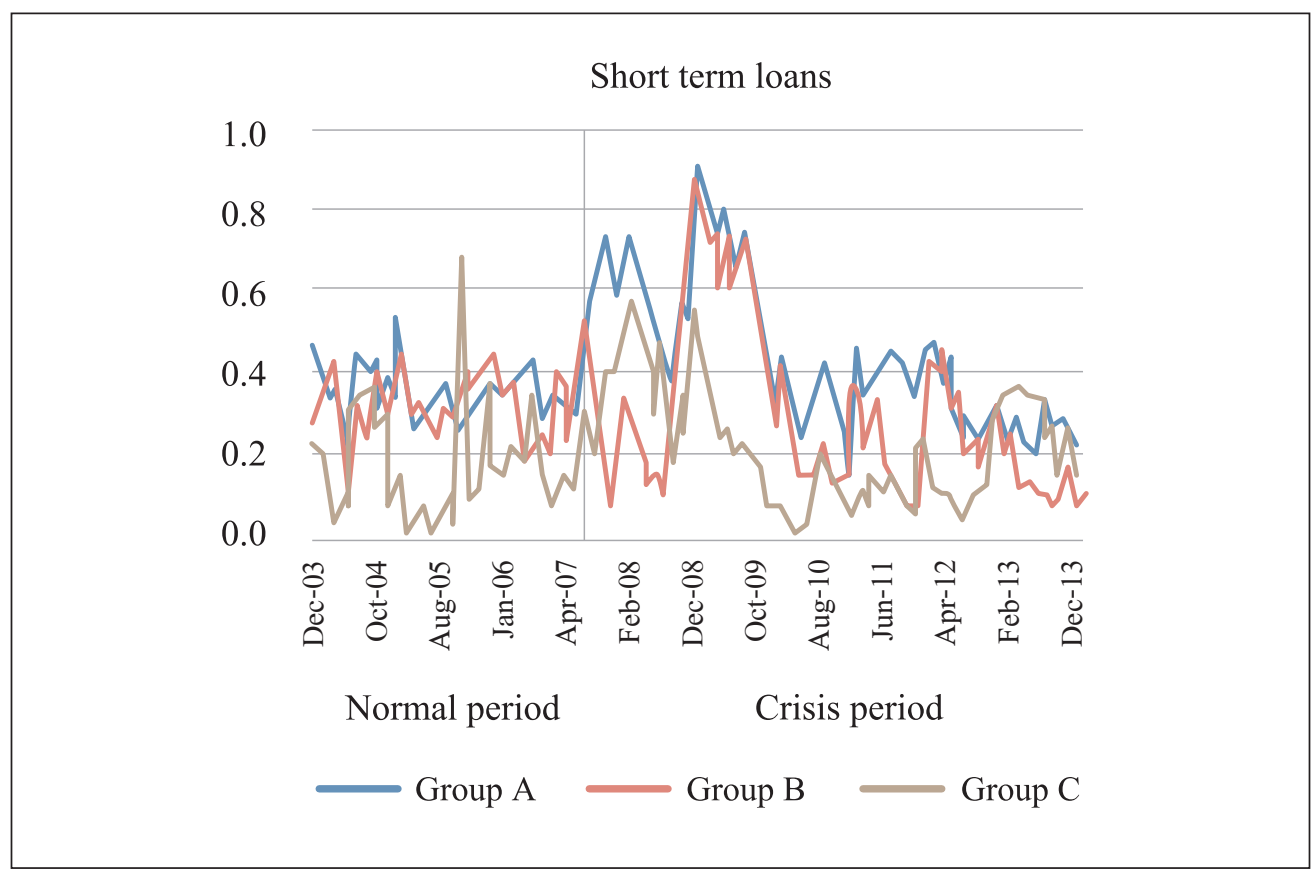

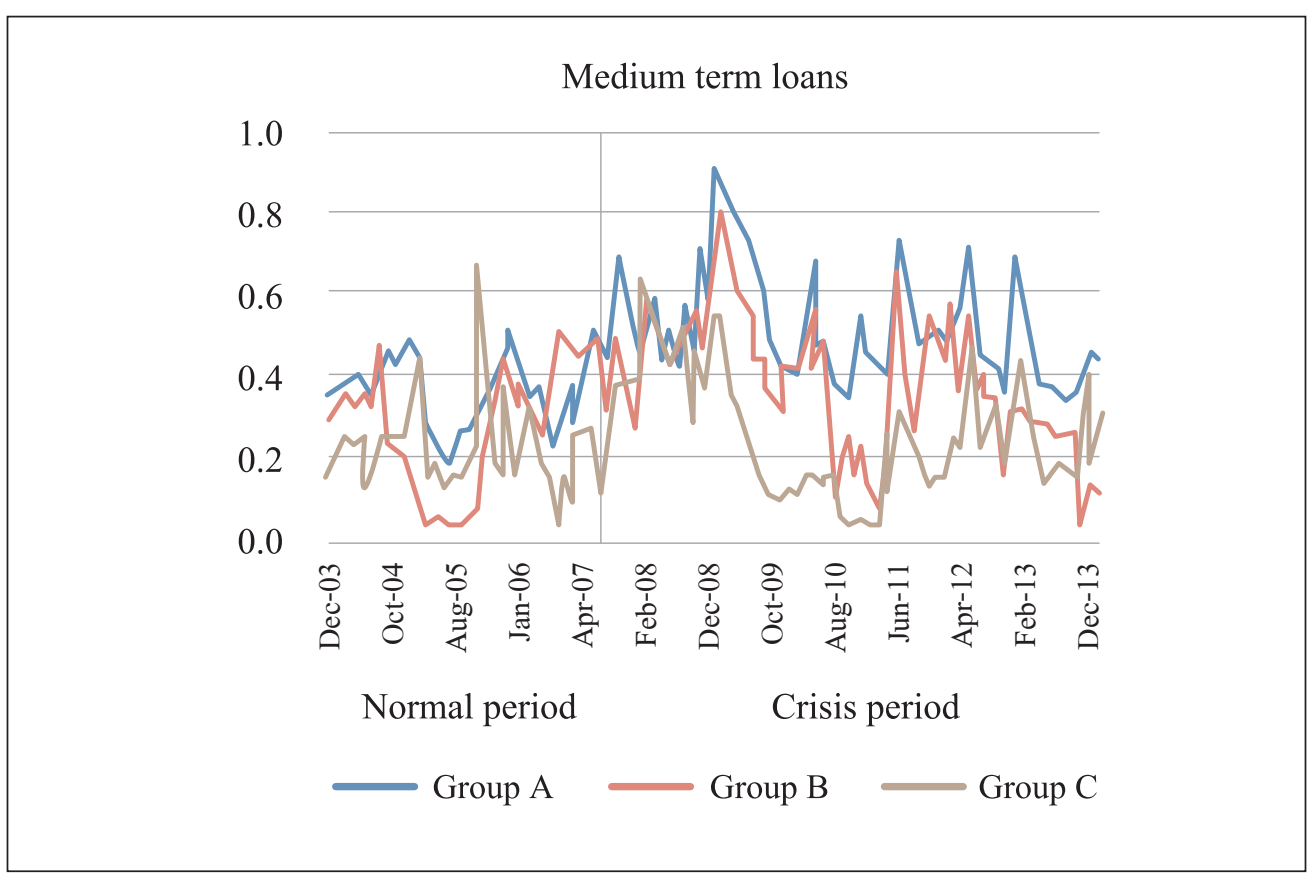




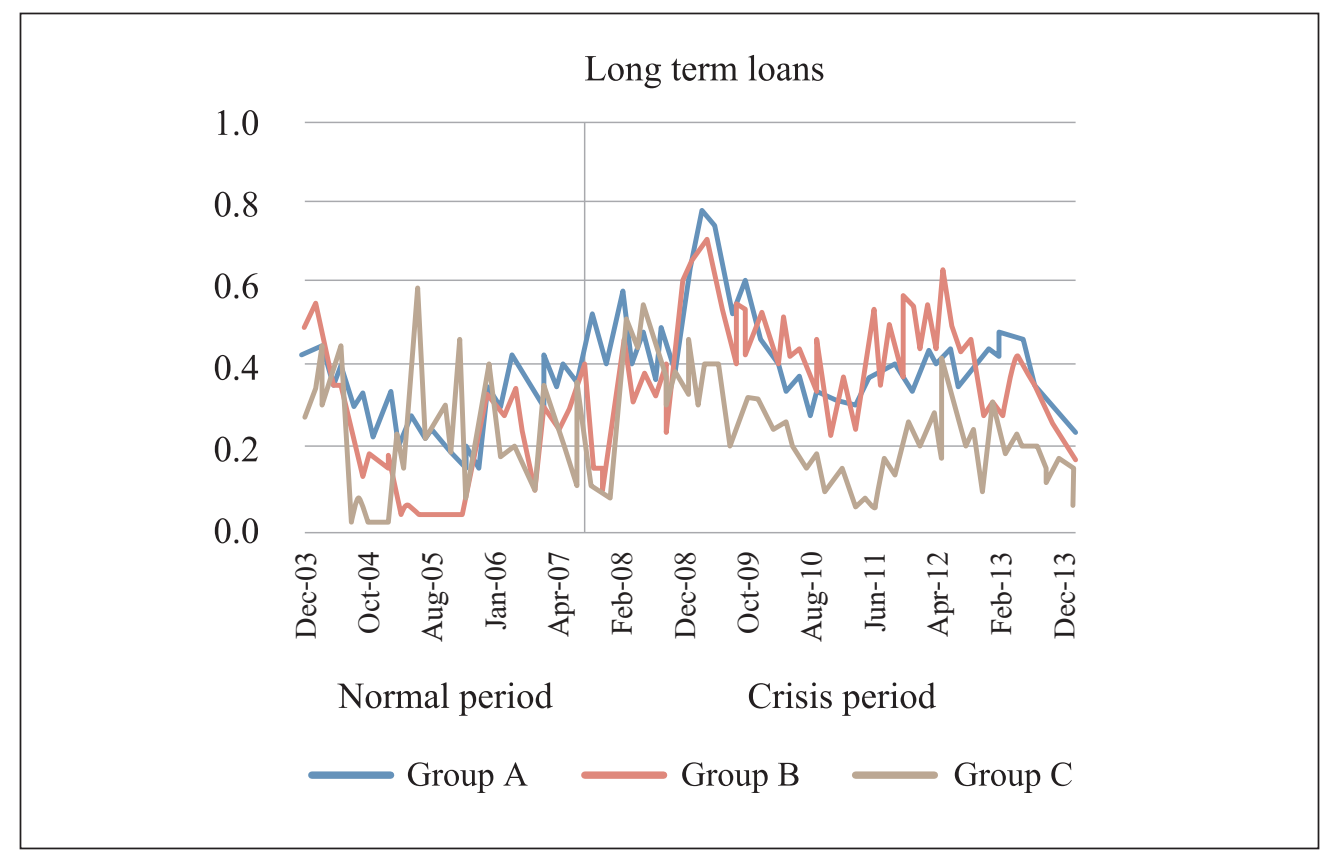

(Note) The figure displays variance ratio for each group across the sub-periods, namely, normal period and crisis period for loan products.

\section{Loans}

In the case of loans, results (Figure 6) show that the variance ratio displayed by the economies is very low across all maturities. It remains below 0.4 throughout the sample period. The exception being the period starting from the onset of the GFC up to the onset of the EDC. This may be attributed to the contagion gripping the globe. Although it fell thereafter, the levels remained higher than those in the normal period. This indicates toward the presence of contagion rather than an improvement in the process of integration. Although no stark difference in the degree of integration is noticed, Group C displays lower integration than Group A and Group B, particularly during the Crisis period. This can be attributed to their limited exposure to GIIPS economies than the economies of Group A and B. We see that the variance ratio rises slightly for the economies during the GFC, and falls thereafter; however, it remains above the levels during the Normal period. This indicates the presence of contagion.

Overall, as compared with the deposit rates, the loan interest rates display a lower degree of integration. The difference is more pronounced in the case of short- and medium-term interest rates. In the case of long term though, savings and lending rates show very low convergence. 


\begin{tabular}{|c|c|c|c|c|c|c|c|c|c|c|c|c|c|c|}
\hline & & $\frac{\Perp}{\infty}$ & 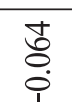 & 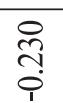 & & & $\frac{\Delta}{\omega}$ & ôे & oे & & & $\frac{\Delta}{\omega n}$ & $\stackrel{0}{0}$ & 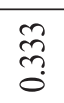 \\
\hline & & $\frac{\pi}{\omega}$ & $\begin{array}{l}\infty \\
\stackrel{\infty}{\subseteq} \\
+1\end{array}$ & $\begin{array}{l}\text { 导 } \\
\text { i }\end{array}$ & & & $\frac{\pi}{\omega}$ & $\begin{array}{l}\text { ¿ } \\
\stackrel{0}{0}\end{array}$ & $\begin{array}{l}\text { ¿ } \\
\stackrel{0}{0}\end{array}$ & & & $\frac{\pi}{n}$ & $\begin{array}{l}\stackrel{a}{\Xi} \\
\overrightarrow{0}\end{array}$ & $\underset{\ominus}{F}$ \\
\hline & U & $\stackrel{\Xi}{\Xi}$ & 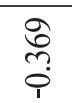 & $\begin{array}{l}\stackrel{y}{y} \\
\stackrel{1}{*}\end{array}$ & & $\underset{\Omega}{U}$ & $\stackrel{\star}{\leftrightarrows}$ & $\stackrel{n}{\circ}$ & $\hat{o}$ & & $\underset{E}{U}$ & 杀 & $\begin{array}{l}\hat{0} \\
0\end{array}$ & $\begin{array}{l}\mathscr{0} \\
\ddot{0} \\
0\end{array}$ \\
\hline & 总 & 蒙 & $\begin{array}{l}\text { o } \\
\text { in } \\
i\end{array}$ & 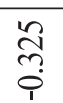 & & $\overline{\mathrm{g}}$ & 藏 & $\hat{8}$ & ठ̊. & & تٕن & 婳 & ठิे & त़ \\
\hline & & $\sum^{\pi}$ & $\frac{m}{\vec{n}}$ & $\underset{0}{0}$ & & & $\bar{\Sigma}$ & 훙 & $\stackrel{\Delta}{0}$ & & & $\sum^{\pi}$ & \&̊ & ڤ્તి \\
\hline & & s & $\begin{array}{l}\hat{\overline{\hat{j}}} \\
\bar{i}\end{array}$ & $\begin{array}{l}n \\
\hat{n} \\
i\end{array}$ & & & 今ે & $\vec{\delta}$ & ठे. & & & है & \&: & $\frac{8}{0}$ \\
\hline & & $\grave{\Xi}$ & $\begin{array}{l}\vec{I} \\
\stackrel{F}{i}\end{array}$ & 导. & & & $\grave{0}$ & ô̊. & $\overrightarrow{\bar{\sigma}}$ & & & $\ddot{0}$ & $\begin{array}{l}\mathbb{t} \\
\stackrel{0}{0}\end{array}$ & 官 \\
\hline & & 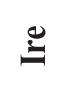 & $\begin{array}{l}\hat{n} \\
\hat{n} \\
\hat{i}\end{array}$ & 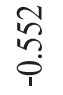 & & & $\stackrel{\Xi}{\varrho}$ & ๕̊ & $\stackrel{\text { ô }}{\circ}$ & & & $\stackrel{\varrho}{\varrho}$ & તิ & ণ্ \\
\hline 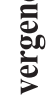 & $\overline{\bar{Z}}$ & تَّ & $\begin{array}{l}n \\
\vec{t} \\
i \\
i\end{array}$ & $\begin{array}{l}\text { ì } \\
\text { în }\end{array}$ & 䔍 & $\overrightarrow{\bar{z}}$ & 입 & $\stackrel{\vec{\sigma}}{\circ}$ & $\stackrel{n}{a}$ & 䞤 & $\overline{\bar{z}}$ & ت் & ڤ్తి & ڤ్ \\
\hline $\begin{array}{l}\overline{0} \\
\text { Jँّ. }\end{array}$ & & 夆 & $\begin{array}{l}\bar{n} \\
\tilde{n} \\
\bar{\varphi}\end{array}$ & $\begin{array}{l}0 \\
0 \\
0 \\
0\end{array}$ & $\begin{array}{l}8 \\
\tilde{E} \\
\tilde{E}\end{array}$ & & 注 & ô. & ষ্. & 离 & & 寻 & $\begin{array}{l}\infty \\
\stackrel{\infty}{y}\end{array}$ & 辇 \\
\hline 苛 & & $\stackrel{n}{\xi}$ & $\begin{array}{c}0 \\
\text { n. } \\
i\end{array}$ & $\begin{array}{l}\hat{0} \\
\stackrel{0}{0} \\
\stackrel{0}{0}\end{array}$ & $\ddot{\ddot{\theta}}$ & & $\stackrel{n}{\gtrless}$ & ᄋ్ & ఫ্ & $\begin{array}{l}\tilde{U} \\
\bar{\Xi} \\
\bar{E}\end{array}$ & & $\stackrel{n}{z}$ & $\frac{\pi}{2}$ & 导 \\
\hline & & के & $\begin{array}{l}\bar{n} \\
\overline{1} \\
\hat{i}\end{array}$ & 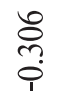 & 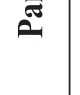 & & है & ôे & ఠ̊ & & & कू & $\begin{array}{l}\vec{\infty} \\
\stackrel{0}{0}\end{array}$ & 势 \\
\hline & & 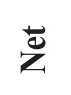 & 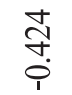 & 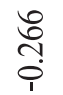 & & & 艺 & 苛 & $\stackrel{\text { ô }}{0}$ & & & $\overrightarrow{\ddot{z}}$ & $\stackrel{\infty}{\dddot{1}}$ & तิ \\
\hline & 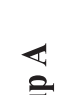 & $\Xi$ & 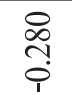 & 孚 & & 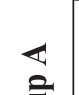 & $\Xi$ & $\bar{\Xi}$ & o̊ & & $\stackrel{\mathbb{a}}{\mathbb{a}}$ & $\Xi$ & 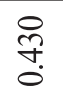 & $\frac{0}{n}$ \\
\hline & Uే & ثँّ & $\begin{array}{l}n \\
\hat{n} \\
\hat{c}\end{array}$ & 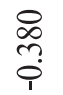 & & Uై & ș & ఠ̊ & ఠ̊ & & ثี & $\bar{\Xi}$ & I̊: & $\begin{array}{l}\infty \\
i n \\
\vdots \\
0\end{array}$ \\
\hline & & $\stackrel{0}{=}$ & $\underset{i}{\stackrel{R}{i}}$ & 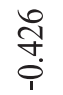 & & & 总 & ᄋ్ & ᄋ్̣. & & & 岂 & ڤ్ণ & ợ \\
\hline & & $\bar{\Phi}$ & 密 & 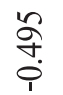 & & & $\bar{\varpi}$ & ộ & o̊ & & & $\Phi$ & @ọ. & ホ্ণ \\
\hline & & & 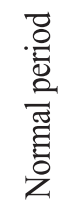 & 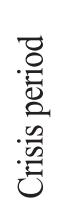 & & & & 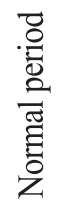 & 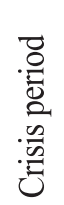 & & & & 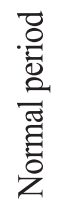 & 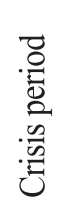 \\
\hline
\end{tabular}




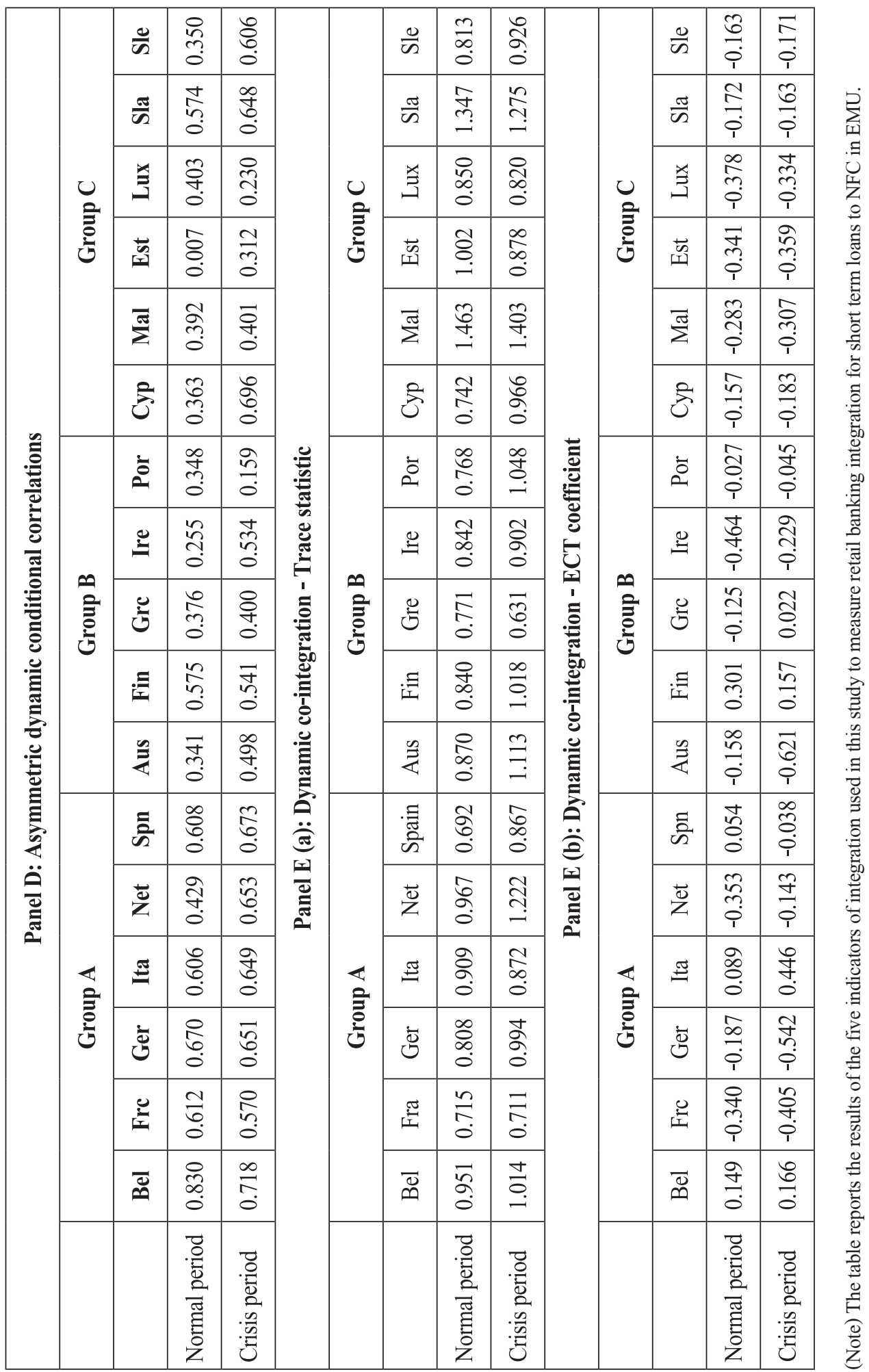




\section{Asymmetric dynamic conditional correlation}

Figure 7. Asymmetric dynamic conditional correlation of deposits
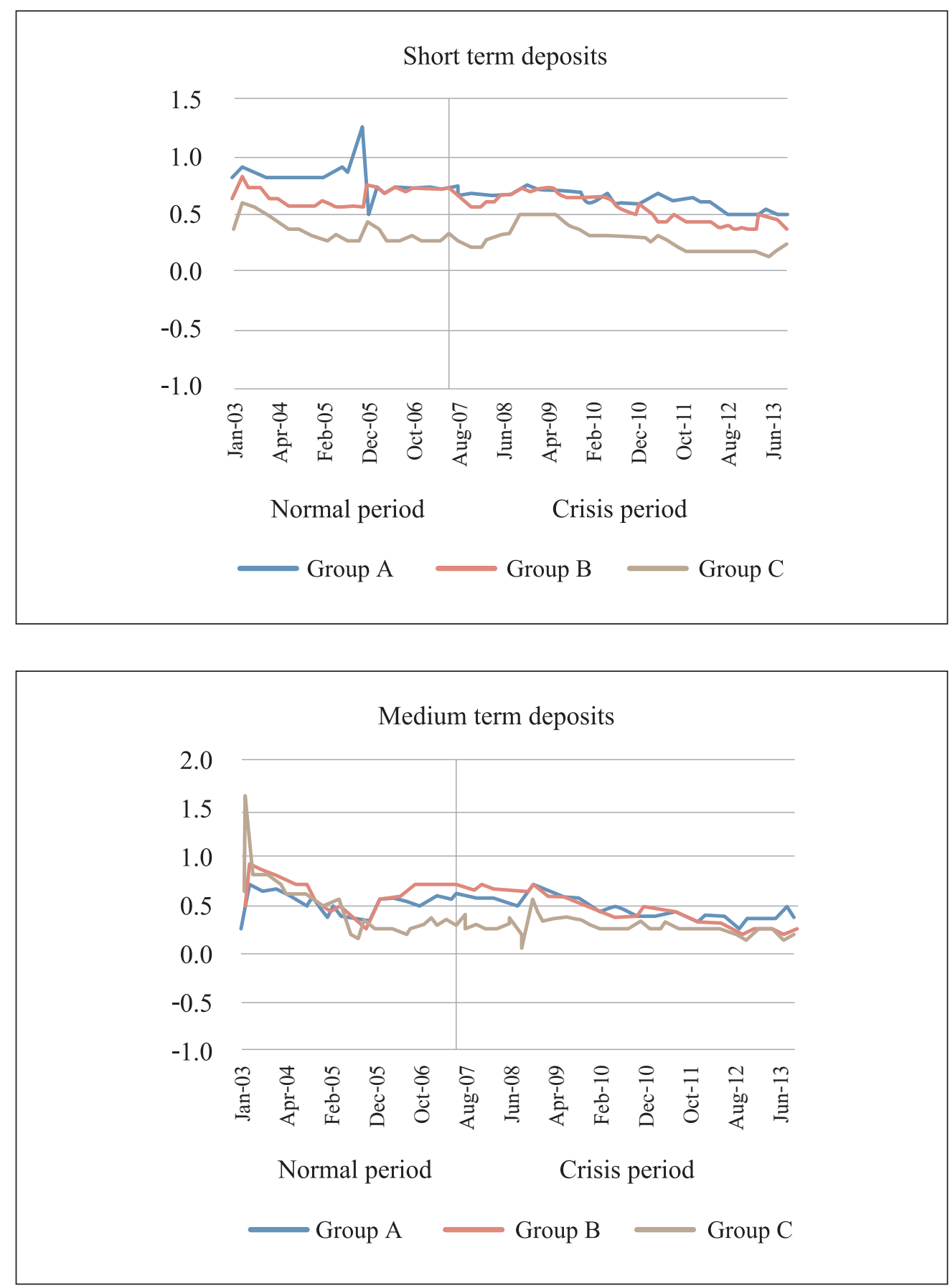


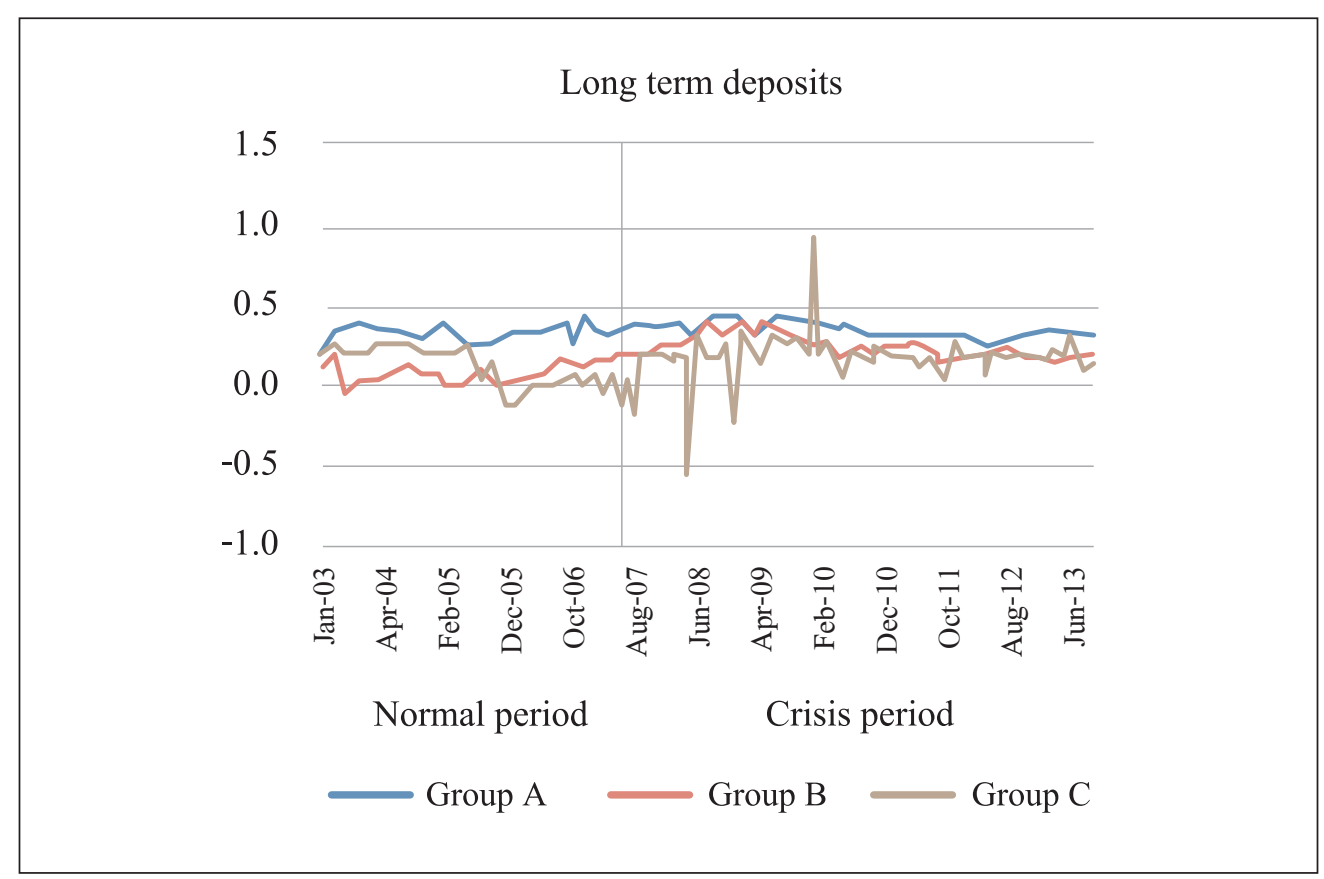

(Note) The figures display ADCC values for each group across the sub-periods, namely, normal period and crisis period, separately for deposit and loan products.

\section{Deposits}

The results for the analysis (Figure 7) reveal that the short-term deposit rates show the highest correlation, followed closely by the medium-term rates; however, the longterm deposit rates lag behind substantially and show very weak correlation throughout the sample period. Group A shows the highest correlation for the short term up to the beginning of 2006; otherwise, for both the short-term and medium-term deposits, Group A and Group B display similar correlation levels, and these are higher than that of Group C. In the case of the long term, however, Group A takes the lead. While both for shortand medium-term deposits, all the economies show a decline in correlation during the crisis, for the long term, it remains almost unchanged and still negligibly low. France emerges as the most strongly correlated economy for short- and long-term rates, while for medium-term rates, Germany shows the highest correlation. 


\begin{tabular}{|c|c|c|c|c|c|c|c|c|c|c|c|c|c|c|}
\hline & & $\stackrel{\circlearrowright}{\mathscr{\omega}}$ & 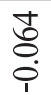 & 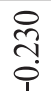 & & & $\frac{\varrho}{\sigma}$ & $\stackrel{8}{8}$ & \&े & & & $\frac{0}{\sigma}$ & $\stackrel{g}{\circ}$ & $\tilde{\tilde{\sigma}}$ \\
\hline & & $\frac{\sigma}{\widetilde{\sigma}}$ & $\frac{\infty}{\stackrel{\infty}{+}}$ & $\begin{array}{l}\text { 导 } \\
\text { : }\end{array}$ & & & $\frac{\pi}{\not 2}$ & ¿্. & ষ্ণ & & & $\frac{\pi}{\widetilde{L}}$ & $\stackrel{g}{\Xi}$ & 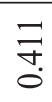 \\
\hline & U & $\stackrel{\circlearrowright}{\Xi}$ & $\begin{array}{l}\text { ôे } \\
\text { ?n? } \\
\text { ? }\end{array}$ & 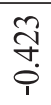 & & U & $\stackrel{\Xi}{\Xi}$ & $\stackrel{2}{8}$ & 용 & & $\begin{array}{l}U \\
\varrho\end{array}$ & $\stackrel{\Xi}{\Xi}$ & $\frac{5}{0}$ & $\begin{array}{l}\mathscr{\infty} \\
0 \\
0\end{array}$ \\
\hline & $\stackrel{2}{3}$ & 泀 & 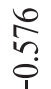 & ڤె & & $\stackrel{\circ}{0}$ & 㟥 & $\hat{8}$ & \& & & $\stackrel{ }{0}$ & 荎 & ڤે & $\stackrel{+}{\stackrel{+}{0}}$ \\
\hline & & $\bar{\Sigma}^{\bar{\Xi}}$ & $\frac{m}{\tilde{n}}$ & $\frac{m}{0}$ & & & $\bar{\Xi}$ & $\stackrel{\partial}{\circ}$ & $\underset{0}{\stackrel{t}{0}}$ & & & $\sum^{\bar{\sigma}}$ & \&̊. & 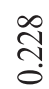 \\
\hline & & 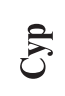 & $\begin{array}{l}\hat{\curvearrowright} \\
\hat{1}\end{array}$ & $\begin{array}{l}n \\
\stackrel{n}{n} \\
?\end{array}$ & & & కె & $\underset{\stackrel{\sigma}{O}}{\stackrel{0}{0}}$ & ఫ્రి & & & కె & $\stackrel{8}{8}$ & $\begin{array}{l}8 \\
0 \\
0\end{array}$ \\
\hline & & $\dot{\Xi}$ & $\underset{\stackrel{J}{~}}{\stackrel{\nabla}{0}}$ & 导 & & & $\dot{\bar{a}}$ & 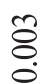 & 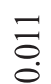 & & & $\stackrel{\partial}{0}$ & to & $\hat{\sigma}$ \\
\hline & & $\stackrel{\circlearrowright}{\Xi}$ & $\hat{n}$ & 華 & & & $\stackrel{\Xi}{\Xi}$ & ๕ి & $\tilde{\delta}$ & & & $\stackrel{\varrho}{=}$ & త్రి & ఫั \\
\hline 递 & $\stackrel{\infty}{0}$ & U⿺乚一 & $\begin{array}{l}n \\
\stackrel{n}{*} \\
\stackrel{p}{p}\end{array}$ & స్తి & 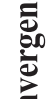 & $\overline{0}$ & تِّ & $\stackrel{+}{\stackrel{\Delta}{0}}$ & $\stackrel{n}{\circ}$ & & 五 & Uై & $\begin{array}{l}\text { గ్ర } \\
\text { రై }\end{array}$ & 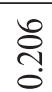 \\
\hline $\begin{array}{l}\tilde{E} \\
0 \\
\tilde{J}\end{array}$ & & 注 & 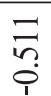 & $\begin{array}{l}0 \\
0 \\
0 \\
0\end{array}$ & Ё & & 㭉 & ڤి & \&̊. & & & 汇 & $\frac{\infty}{\stackrel{\infty}{\sigma}}$ & $\stackrel{n}{\stackrel{r}{\sigma}}$ \\
\hline 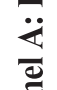 & & $\stackrel{\varrho}{\xi}$ & $\begin{array}{l}\text { ? } \\
\text { ?n } \\
0\end{array}$ & $\stackrel{\infty}{\infty}$ & $\ddot{\theta}$ & & $\stackrel{\varrho}{\xi}$ & ڤి & ষ্ণ & 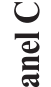 & & $\stackrel{\varrho}{E}$ & $\stackrel{\sim}{2}$ & 守. \\
\hline$\stackrel{\sigma}{\circ}$ & & ڤี & $\stackrel{n}{n}$ & 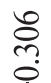 & $\bar{\Xi}$ & & ڤี & ?ִ & 요 & & & ڤँ & $\vec{\infty}$ & f̛ \\
\hline & & $\bar{z}$ & 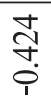 & $\begin{array}{l}\text { o. } \\
\text { r̦ } \\
\text { i }\end{array}$ & & & ż & ¿্. & ஜे & & & Zँ & $\stackrel{\infty}{\stackrel{0}{0}}$ & గ్రి \\
\hline & 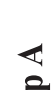 & $\stackrel{\Xi \Xi}{\Xi}$ & $\begin{array}{l}\stackrel{0}{0} \\
\text { ஸి }\end{array}$ & 㕝 & & $=$ & $\Xi$ & $\ddot{8}$ & $\stackrel{8}{8}$ & & 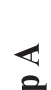 & $\stackrel{\Xi}{=}$ & $\stackrel{\text { ণ }}{\stackrel{5}{0}}$ & $\frac{0}{n}$ \\
\hline & ț & 焉 & $\stackrel{n}{n}$ & $\begin{array}{l}\stackrel{\infty}{\infty} \\
\text { ?. }\end{array}$ & & 包 & 它 & ণి & ช్ & & $\vec{J}$ & Uूँ & 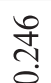 & $\stackrel{\infty}{i n}$ \\
\hline & & $\stackrel{e}{L}$ & $\vec{R}$ & $\stackrel{\stackrel{\circ}{+}}{\stackrel{5}{0}}$ & & & 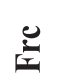 & @ి & ஜ & & & 巳一 & స్ర & \&े \\
\hline & & & $m$ & $\curvearrowleft$ & & & & $m$ & & & & & & $\checkmark$ \\
\hline & & $\bar{\oplus}$ & $\stackrel{P}{i}_{1}^{+}$ & +े & & & 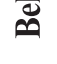 & $\stackrel{8}{\circ}$ & : & & & 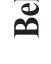 & @̊ & $\stackrel{\mathfrak{\leftarrow}}{\circ}$ \\
\hline & & & 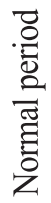 & 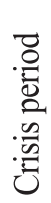 & & & & 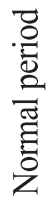 & 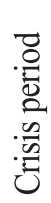 & & & & 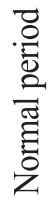 & 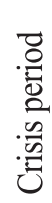 \\
\hline
\end{tabular}




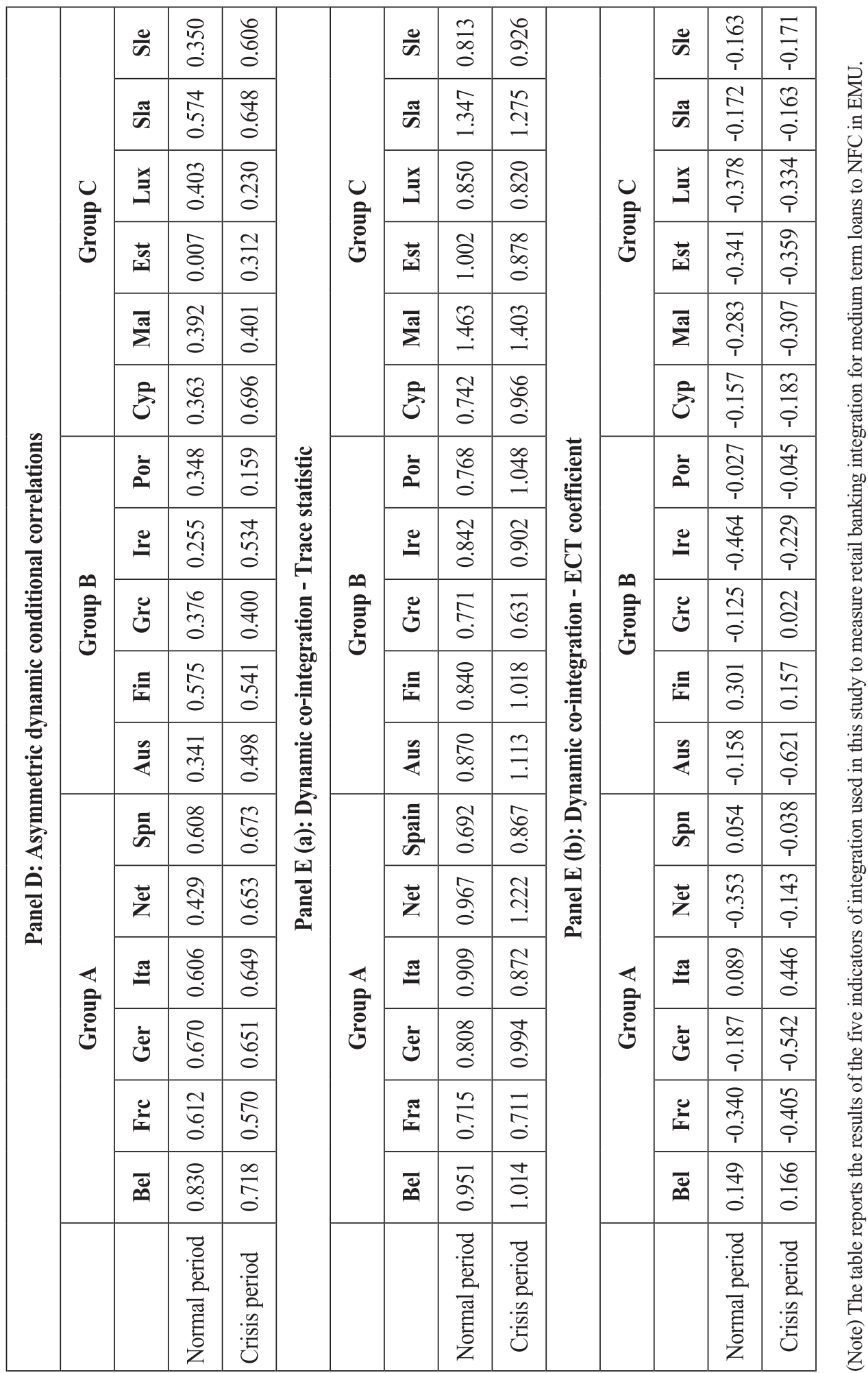


Figure 8. Asymmetric dynamic conditional correlation of loans
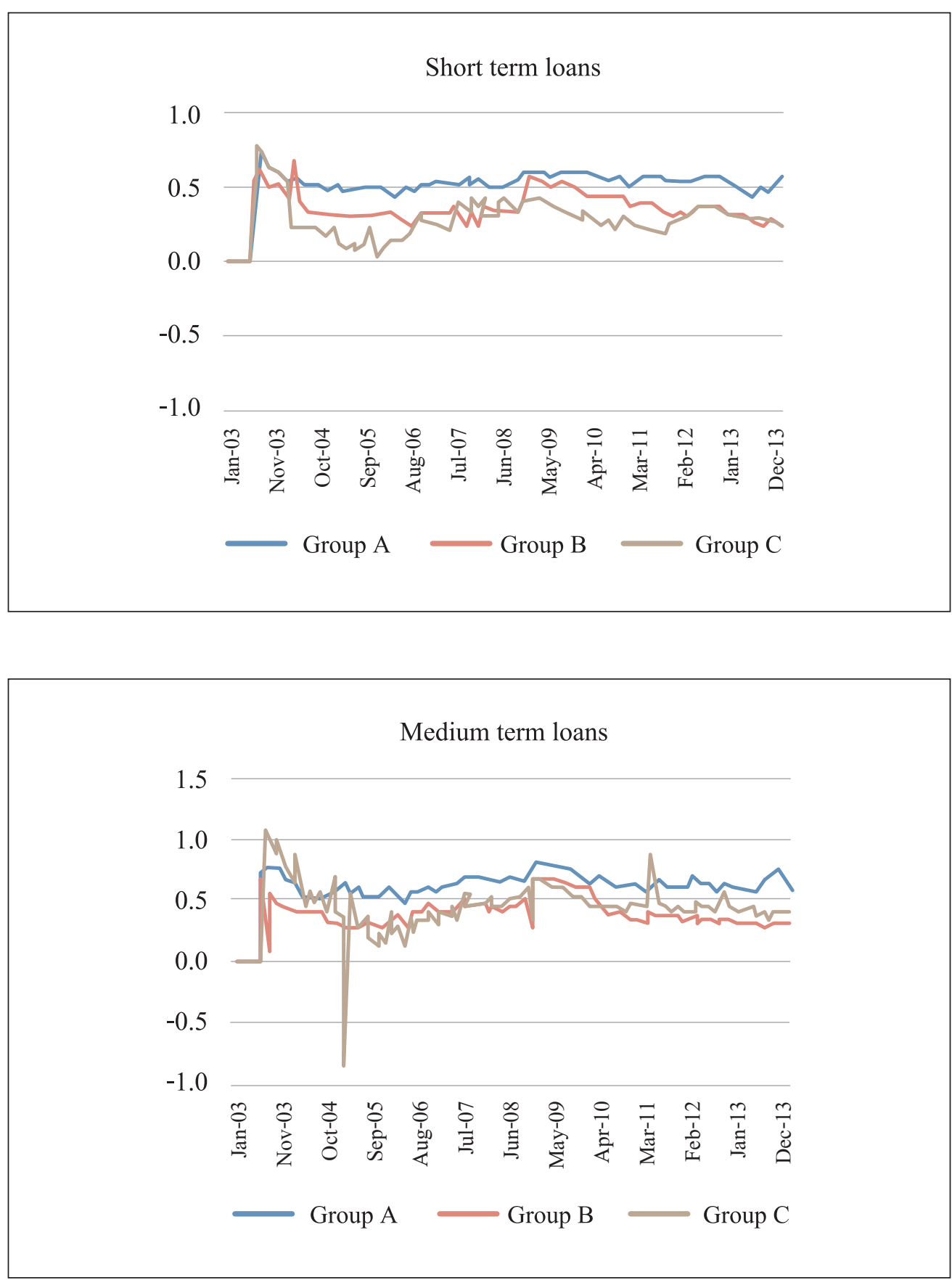


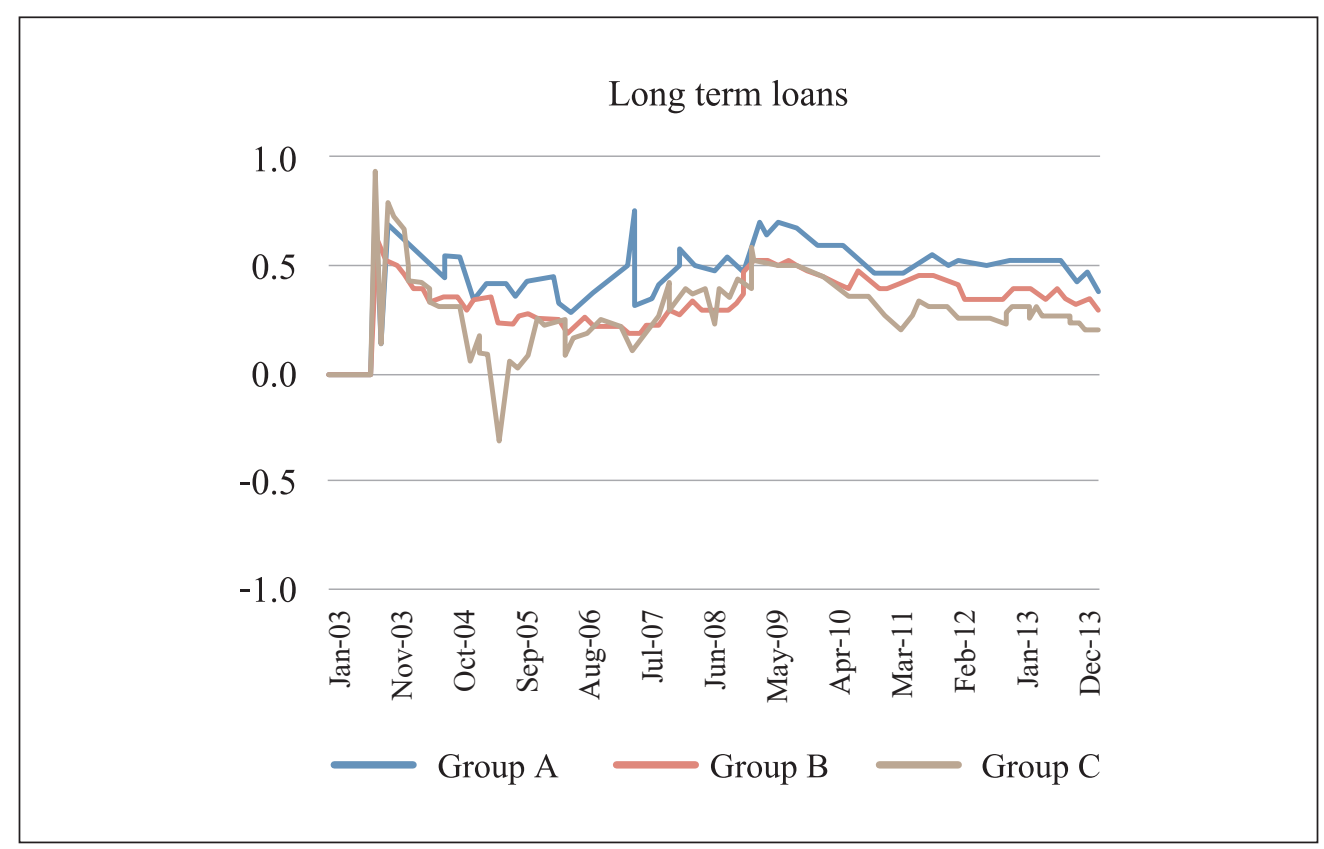

(Note) The figures display ADCC values for each group across the sub-periods, namely, normal period and crisis period, separately for deposit and loan products.

\section{Loans}

Figure 4 displays the ADCC results for the short-, medium-, and long-term loan rates for Group A, Group B, and Group C, respectively. The analysis of loan interest rates shows that overall the correlation values are very low for the entire sample set across all maturities. There is an upward trend up to the first quarter of 2009; thereafter, a declining trend is observed from the first quarter of 2010 across all maturities for Group B and C economies. Group A economies do not register much of a difference. However, even after the decline during the EDC, the correlation levels remain higher than those during the normal period. Across all the maturities, Group A shows the highest correlation values and Group $\mathrm{C}$ the least. Germany emerges as the most strongly integrated economy across all maturities.

Overall, for both loans and deposits, the correlation values displayed are of low magnitude, except for France and Germany for short-term deposits. Further, it can be concluded that the deposit rates display a better degree of integration as compared with loans rates. 


\section{E. Dynamic co-integration}

Figure 9. Trace statistics of deposits
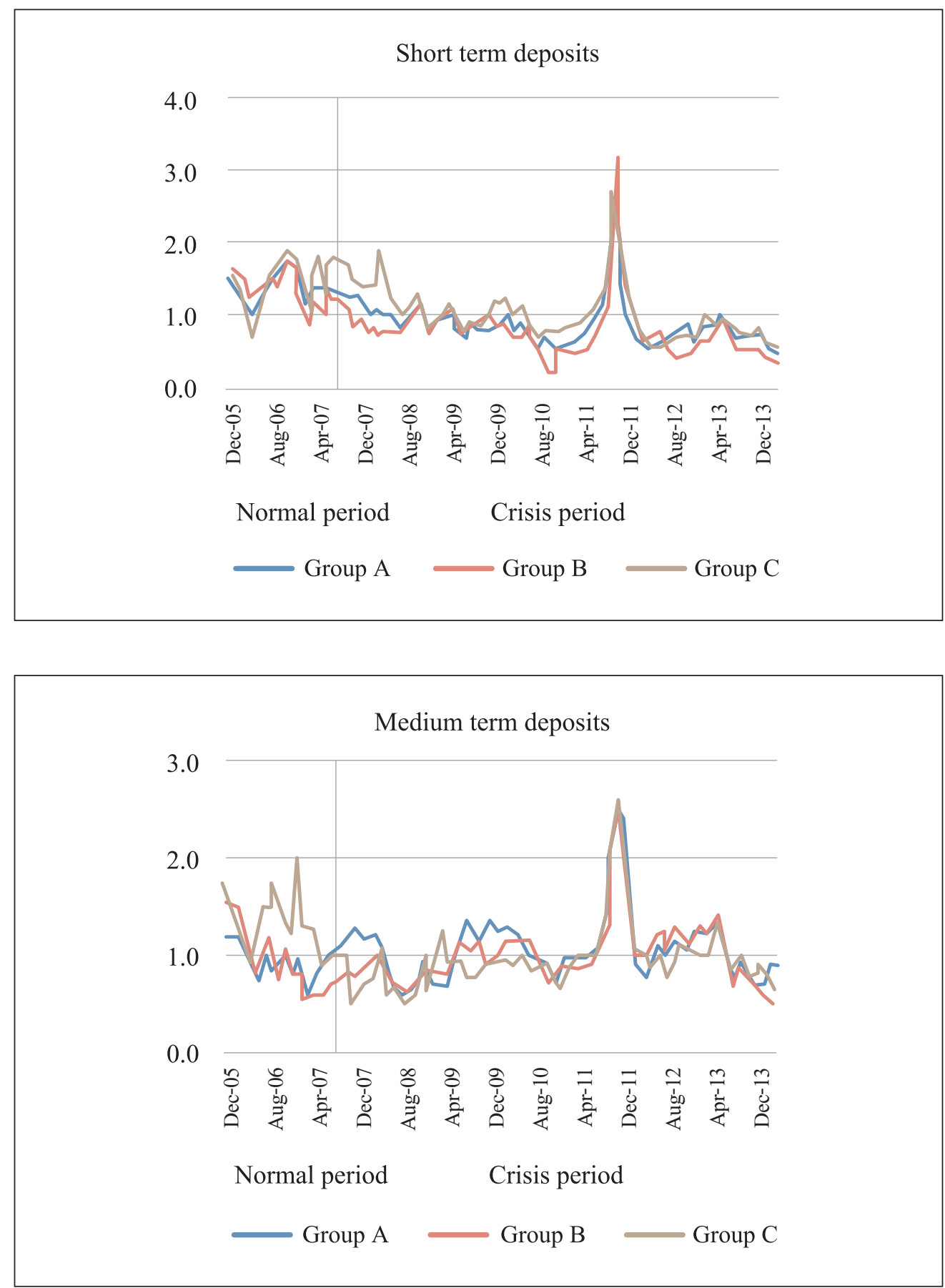


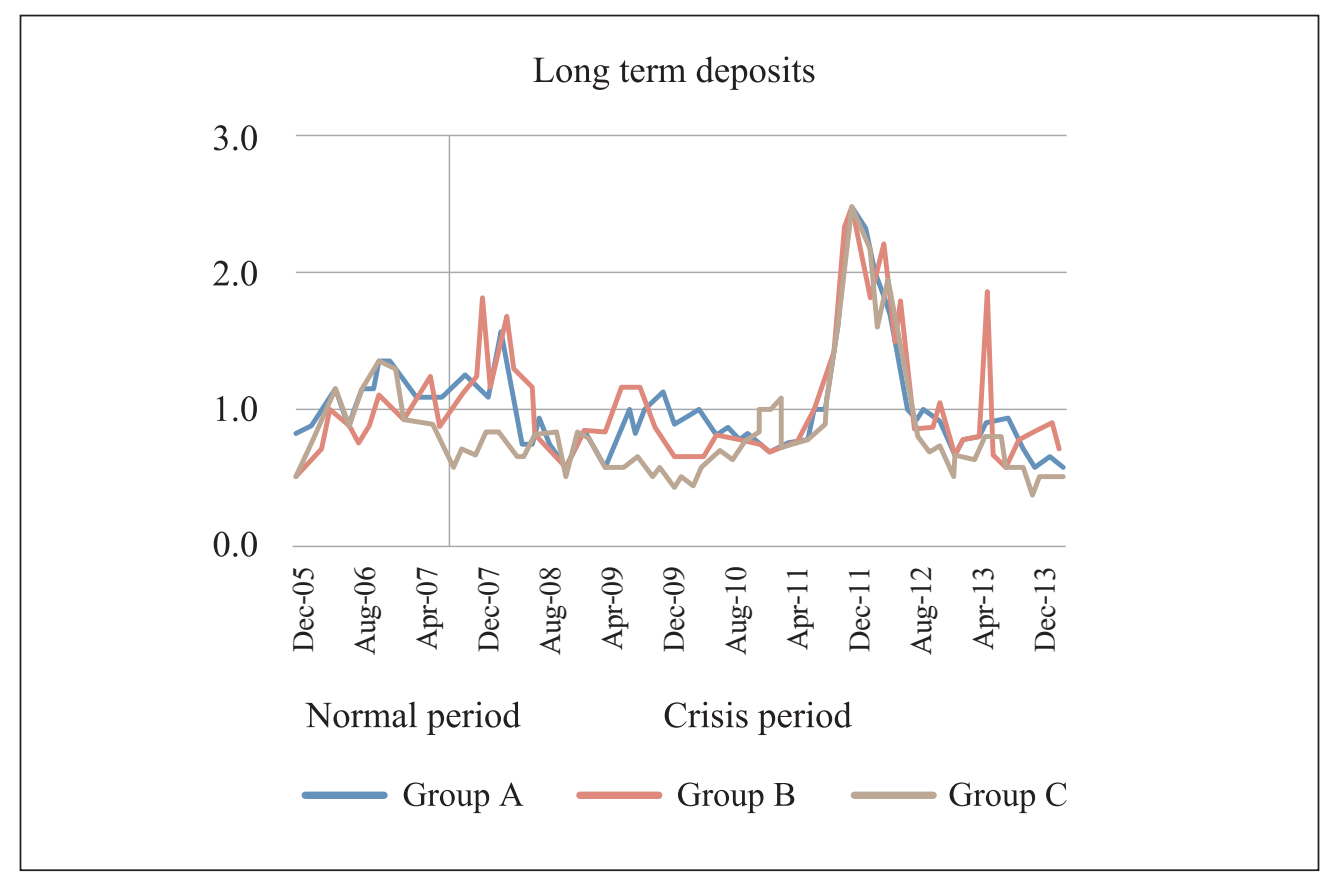

(Note) The figure displays the rolling unweighted average trace statistics (scaled by its critical value) for each group across the sub-periods, namely, normal period and crisis period, separately for deposit and Loan products.

\section{Deposits}

The trace statistics from the dynamic co-integration analysis shows that the shortterm interest rates register stronger signs of co-integration than Group A and B, particularly during the normal period. Figure 9 displays the dynamic co-integration results for the short-, medium-, and long-term deposit rates for Groups A, B, and C, respectively. Long-term deposit does not show co-integration even in the Normal period, while the economies of Group A show higher trace statistics, followed closely by Group B. In Group C, the high trace statistics displayed by Luxembourg improves the group average. The results demonstrate that all the economies register a fall in trace statistics following the onset of the EDC in October 2009. It is noteworthy that all economies displayed signs of co-integration from the fourth quarter of 2011 up to the fourth quarter of 2012. This can be attributed to the positive signs displayed by the Eurozone rescue, i.e., the bailout of Portugal, Italy and Greece that was initiated in May 2011, post the creation of a bailout fund called the European Stability Mechanism. However, this optimism evaporated during 2012 with the onset of the political crisis in Greece, heightened 
unemployment in the Eurozone, increase in borrowing costs for Italy and Spain, and the downgrading of the EU bailout fund by Standard and Poor's. ${ }^{7}$ Further, political turmoil in Greece added to the pessimism in the region. Overall, France and Germany (for longterm rates) from Group A, Austria from Group B, and Luxembourg from Group C display the highest value of trace statistics and show signs of a long-term relationship with the EMU.

Figure 10. Coefficient of error correction term of deposits

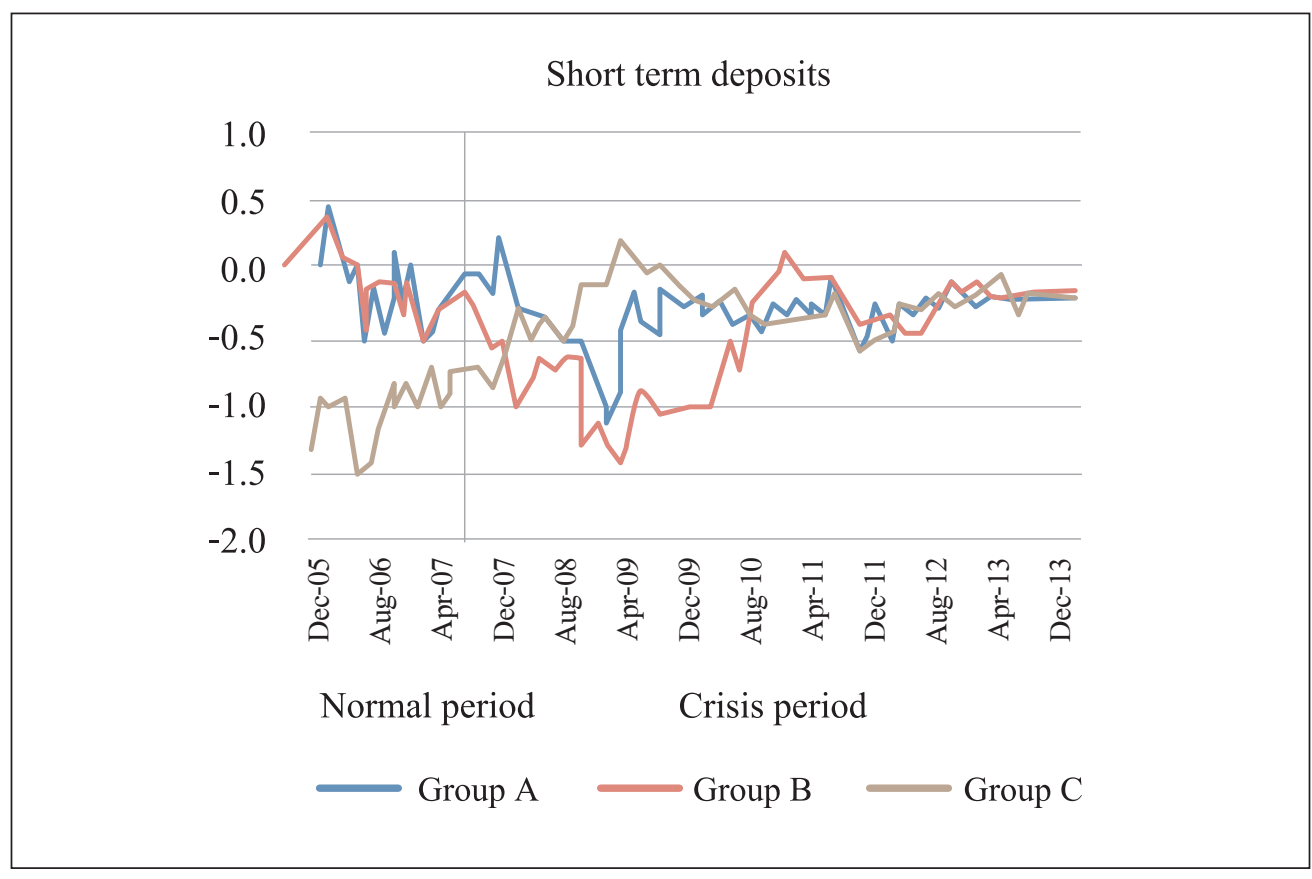

BBC (2012). Timeline: The unfolding Eurozone crisis. Retrieved on $1^{\text {st }}$ September 2015 from http://www.bbc.com/news/business13856580 

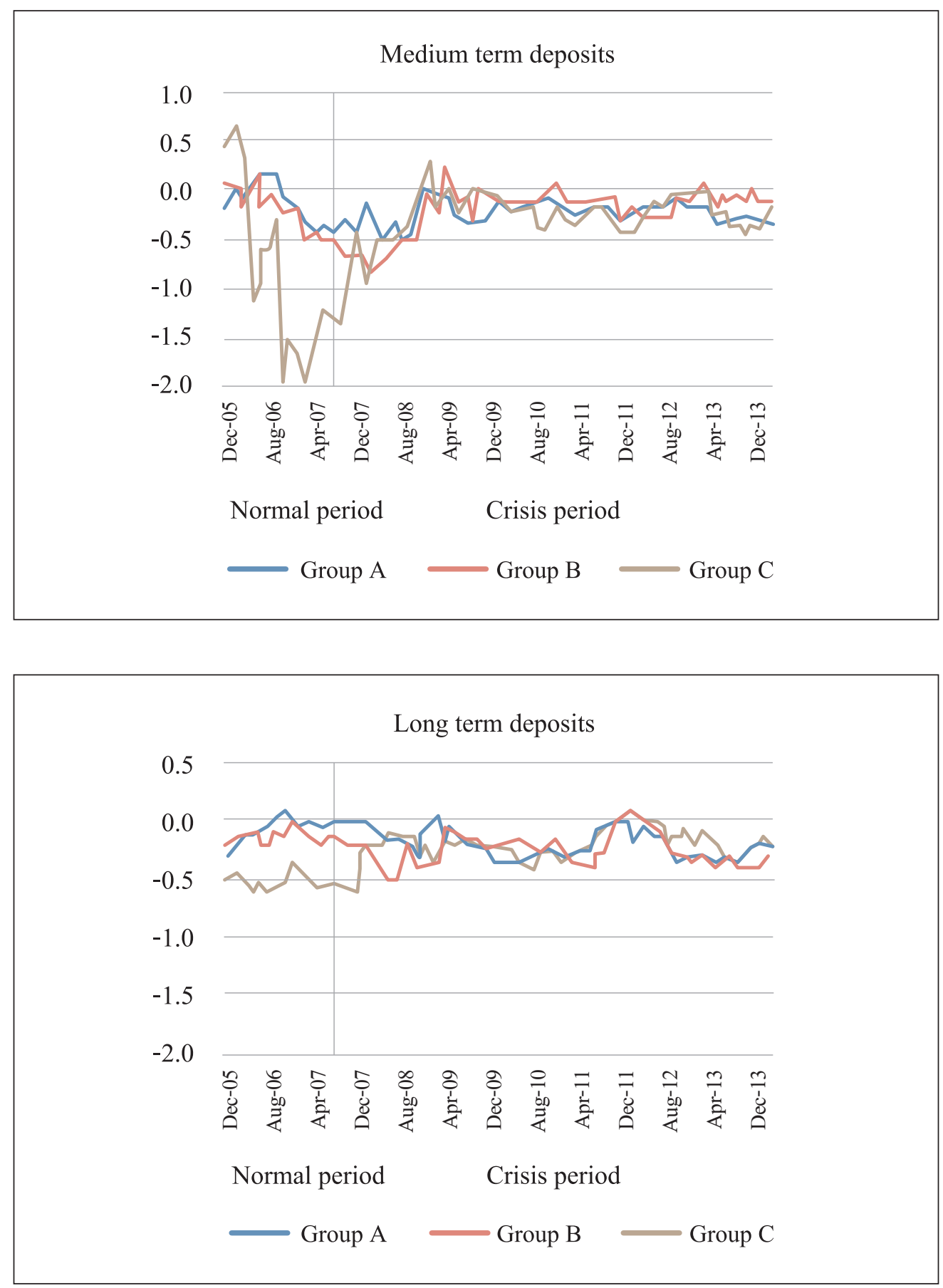

(Note) The figure displays the unweighted average of the absolute values of rolling coefficient of ECT generated from the dynamic co-integration analysis, for each group across the sub-periods, namely, normal period and crisis period, separately for deposit and loan products. 
From the ECT generated by the dynamic co-integration analysis (Figure 10), we can conclude that the long-term deposit rates display negligible speed of adjustment throughout the sample period, thus indicating the tendency of the low efficiency of longterm products to return to long-run equilibrium after a shock. Overall, the short-term deposits show a better speed of convergence, followed closely by medium-term deposits. Group C economies have the lowest speed of convergence, except for Luxembourg, which displays Group B-like behavior. Thus, Group C shows a higher speed of convergence on account of Luxembourg. The adverse impact of a crisis is observed on the speed of adjustment, particularly for short- and medium-term maturities as the alpha values move toward zero. The highest speed of convergence is displayed by Germany (highest positive alpha) and Portugal (highest negative alpha) for short- and mediumterm maturity and by France for long-term maturity deposits. 


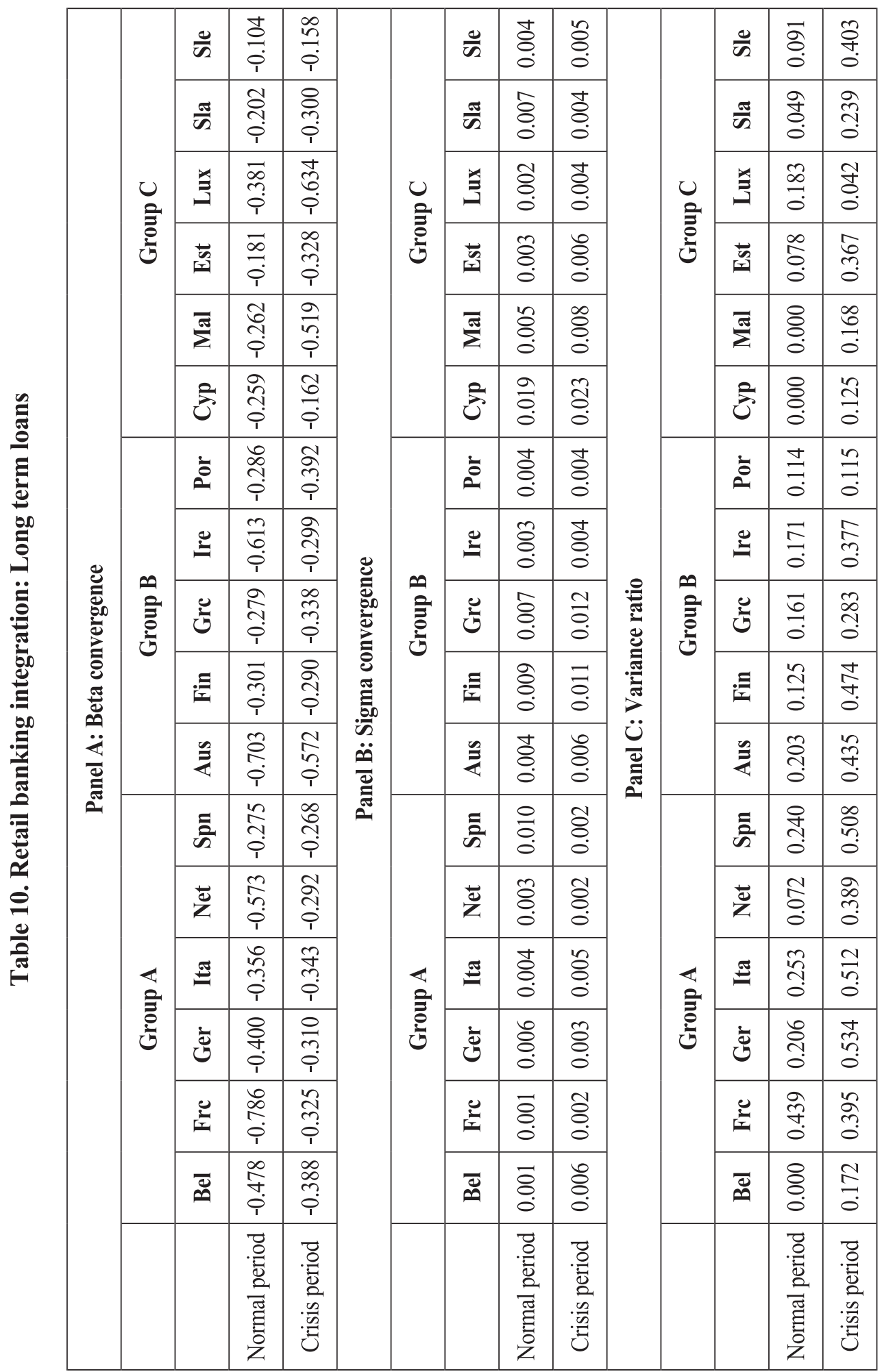




\begin{tabular}{|c|c|c|c|c|c|c|c|c|c|c|c|c|c|c|}
\hline \multirow{18}{*}{ 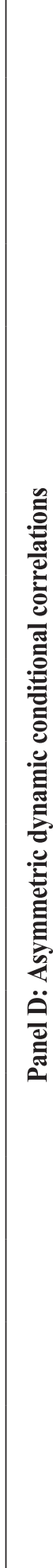 } & \multirow{6}{*}{ כ) } & $\frac{0}{\mathscr{D}}$ & $\begin{array}{l}\text { to } \\
\text { ? } \\
0\end{array}$ & $\underset{0}{\nabla}$ & \multirow{18}{*}{ 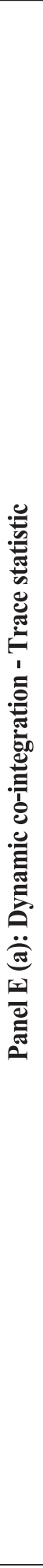 } & \multirow{6}{*}{ 苛 } & $\frac{\mathscr{\sigma}}{\mathscr{a}}$ & $\bar{m}$ & 令 & \multirow{18}{*}{ 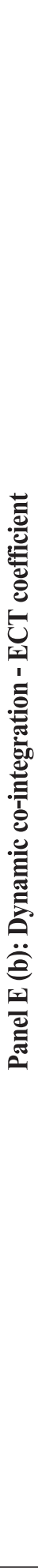 } & \multirow{6}{*}{ U } & 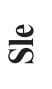 & $\begin{array}{l}\vec{F} \\
\dot{0}\end{array}$ & $\begin{array}{l}\stackrel{+}{0} \\
\stackrel{0}{0}\end{array}$ \\
\hline & & $\frac{\pi}{\tilde{\sigma}}$ & $\frac{2}{0}$ & $\underset{f}{\stackrel{f}{f}}$ & & & $\frac{\sigma}{\mathscr{a}}$ & 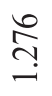 & 官 & & & $\frac{\pi}{\sigma}$ & $\begin{array}{l}0 \\
0 \\
0 \\
0\end{array}$ & $\begin{array}{l}\stackrel{2}{0} \\
\stackrel{0}{0} \\
\stackrel{1}{1}\end{array}$ \\
\hline & & $\stackrel{\triangleq}{\Xi}$ & $\frac{8}{0}$ & $\frac{\Omega}{\sigma}$ & & & $\stackrel{\Xi}{\Xi}$ & $\underline{\underline{0}}$ & 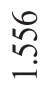 & & & 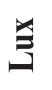 & $\begin{array}{l}\frac{m}{n} \\
\stackrel{n}{n}\end{array}$ & 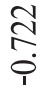 \\
\hline & & 节 & $\frac{1}{8}$ & $\stackrel{n}{m}$ & & & 侌 & $\underset{\mathrm{J}}{\mathrm{J}}$ & 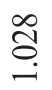 & & & 苞 & $\begin{array}{l}\mathbb{S} \\
\stackrel{1}{0} \\
0\end{array}$ & $\begin{array}{l}\overrightarrow{0} \\
\stackrel{+}{0}\end{array}$ \\
\hline & & $\bar{\Sigma}$ & $\frac{\infty}{\widetilde{\sigma}}$ & $\frac{N}{0}$ & & & $\bar{\Sigma}$ & $\frac{m}{\sigma}$ & $\stackrel{\circ}{\circ}$ & & & $\sum^{\bar{\sigma}}$ & $\begin{array}{l}\infty \\
\stackrel{\infty}{0} \\
\vec{p}\end{array}$ & $\frac{m}{\dot{p}}$ \\
\hline & & 3 & $\stackrel{\hat{n}}{0}$ & $\frac{\infty}{\underset{\sigma}{J}}$ & & & j) & $\frac{2}{\infty}$ & 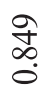 & & & j) & $\frac{\vec{\infty}}{\overrightarrow{0}}$ & $\begin{array}{l}\mathbb{N} \\
\stackrel{0}{0}\end{array}$ \\
\hline & & $\dot{0}$ & $\begin{array}{l}\text { శొ } \\
\text { ర్}\end{array}$ & $\begin{array}{l}\text { ठे } \\
\text { రి }\end{array}$ & & \multirow{5}{*}{ 豙 } & 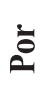 & 官 & $\stackrel{8}{\stackrel{0}{\circ}}$ & & \multirow{5}{*}{$\stackrel{\varrho}{\Xi}$} & 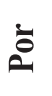 & 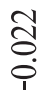 & $\begin{array}{l}\stackrel{P}{0} \\
\stackrel{0}{0}\end{array}$ \\
\hline & & $\stackrel{\circlearrowright}{\Xi}$ & $\begin{array}{l}\text { o } \\
\text { జ్ }\end{array}$ & 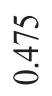 & & & $\stackrel{\Xi}{\Xi}$ & $\frac{⿱ 亠}{2}$ & $\stackrel{ }{\stackrel{0}{0}}$ & & & $\stackrel{\Xi}{ }$ & $\begin{array}{l}\cong \\
\stackrel{0}{0} \\
\stackrel{1}{0}\end{array}$ & $\begin{array}{l}n \\
\text { ô. } \\
\stackrel{1}{1}\end{array}$ \\
\hline & & Uై & $\stackrel{m}{\ddot{0}}$ & 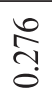 & & & Uँّ & $\begin{array}{l}+ \\
\text { a }\end{array}$ & 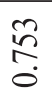 & & & Uై & 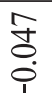 & 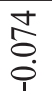 \\
\hline & & 注 & $\frac{n}{n}$ & \begin{tabular}{l} 
ర్t \\
\multirow{0}{0}{}
\end{tabular} & & & 江 & $\frac{8}{\stackrel{R}{\circ}}$ & 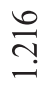 & & & 江 & $\stackrel{8}{\circ}$ & $\underset{0}{\mathbb{0}}$ \\
\hline & & $\stackrel{\varrho}{\xi}$ & $\stackrel{n}{\stackrel{n}{0}}$ & $\stackrel{\vec{\sigma}}{\stackrel{\sigma}{0}}$ & & & $\stackrel{\varrho}{\xi}$ & $\begin{array}{l}\infty \\
\stackrel{2}{\sigma} \\
\stackrel{\sigma}{0}\end{array}$ & 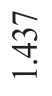 & & & $\stackrel{\varrho}{E}$ & $\begin{array}{l}\text { రె } \\
\text { ?ִ } \\
\text { ? }\end{array}$ & $\stackrel{\vec{\Im}}{\stackrel{+}{+}}$ \\
\hline & & क्ष & $\underset{f}{\stackrel{f}{0}}$ & $\begin{array}{l}n \\
n \\
n\end{array}$ & & \multirow{6}{*}{ 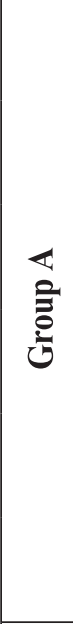 } & 菭 & $\underset{\infty}{=}$ & $\underset{\mathbb{\Delta}}{\stackrel{\Xi}{\sigma}}$ & & \multirow{6}{*}{ 岂 } & ڤ్ & 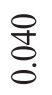 & $\begin{array}{l}\hat{8} \\
\stackrel{0}{0}\end{array}$ \\
\hline & & ¿ & 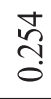 & 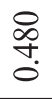 & & & $\sum_{\bar{Z}}^{\overline{0}}$ & 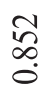 & ஜ & & & $\stackrel{\bar{z}}{\bar{z}}$ & $\begin{array}{l}\infty \\
\stackrel{\text { }}{1} \\
\text { }\end{array}$ & $\stackrel{i}{0}$ \\
\hline & & $\stackrel{\Xi}{\Xi}$ & $\underset{0}{\stackrel{f}{0}}$ & ga & & & $\stackrel{\tilde{\sigma}}{\underline{\Xi}}$ & $\stackrel{\mathscr{f}}{\stackrel{\text { f }}{-}}$ & 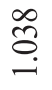 & & & $\Xi$ & $\stackrel{\infty}{0}$ & $\frac{J}{\stackrel{J}{0}}$ \\
\hline & & U. & $\begin{array}{l}\text { ฟ } \\
\text { గุ }\end{array}$ & 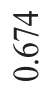 & & & ت্் & 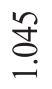 & 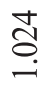 & & & ت্ঠ & $\begin{array}{l}\text { fे } \\
\text { : }\end{array}$ & 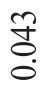 \\
\hline & & 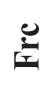 & $\underset{\sigma}{\sigma}$ & $\begin{array}{l}\infty \\
\infty \\
0 \\
0\end{array}$ & & & 哥 & 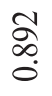 & $\underset{\Xi}{\Xi}$ & & & 莡 & $\begin{array}{l}\text { } \\
\text { } \\
\text { }\end{array}$ & $\begin{array}{l}\infty \\
\stackrel{2}{2} \\
\stackrel{1}{1}\end{array}$ \\
\hline & & $\bar{\Phi}$ & 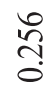 & $\begin{array}{l}\text { రె } \\
\text { nె }\end{array}$ & & & $\bar{\Phi}$ & $\begin{array}{l}\infty \\
\stackrel{\circ}{\circ} \\
0\end{array}$ & $\frac{0}{\infty}$ & & & $\bar{\Phi}$ & $\stackrel{n}{\tilde{N}}$ & 官 \\
\hline & & & 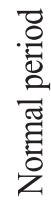 & 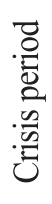 & & & & 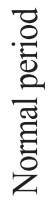 & $\begin{array}{l}\bar{D} \\
. \frac{0}{2} \\
\frac{n}{2} \\
: \frac{n}{2}\end{array}$ & & & & 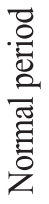 & 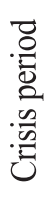 \\
\hline
\end{tabular}


Figure 11. Trace statistics of loans
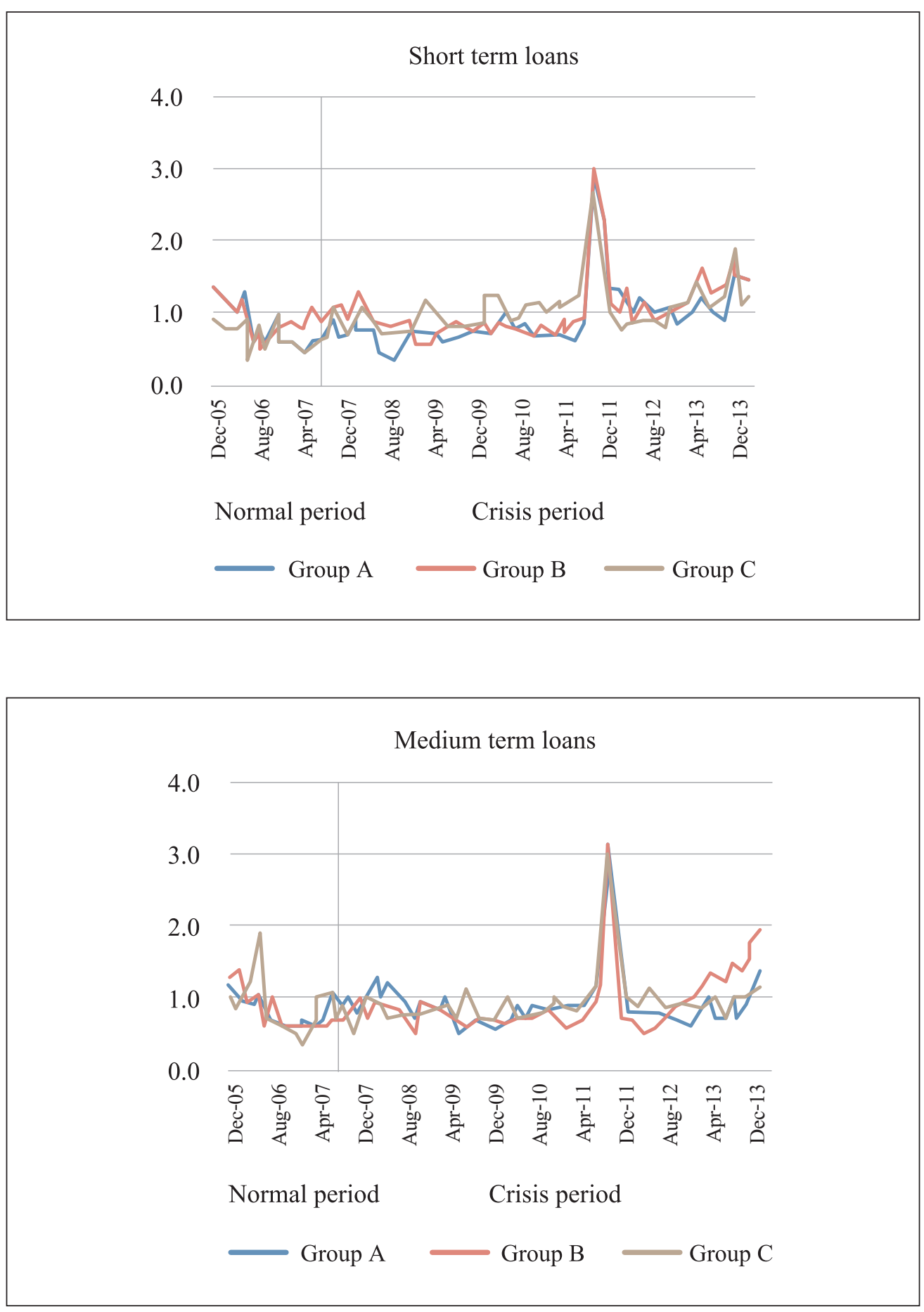


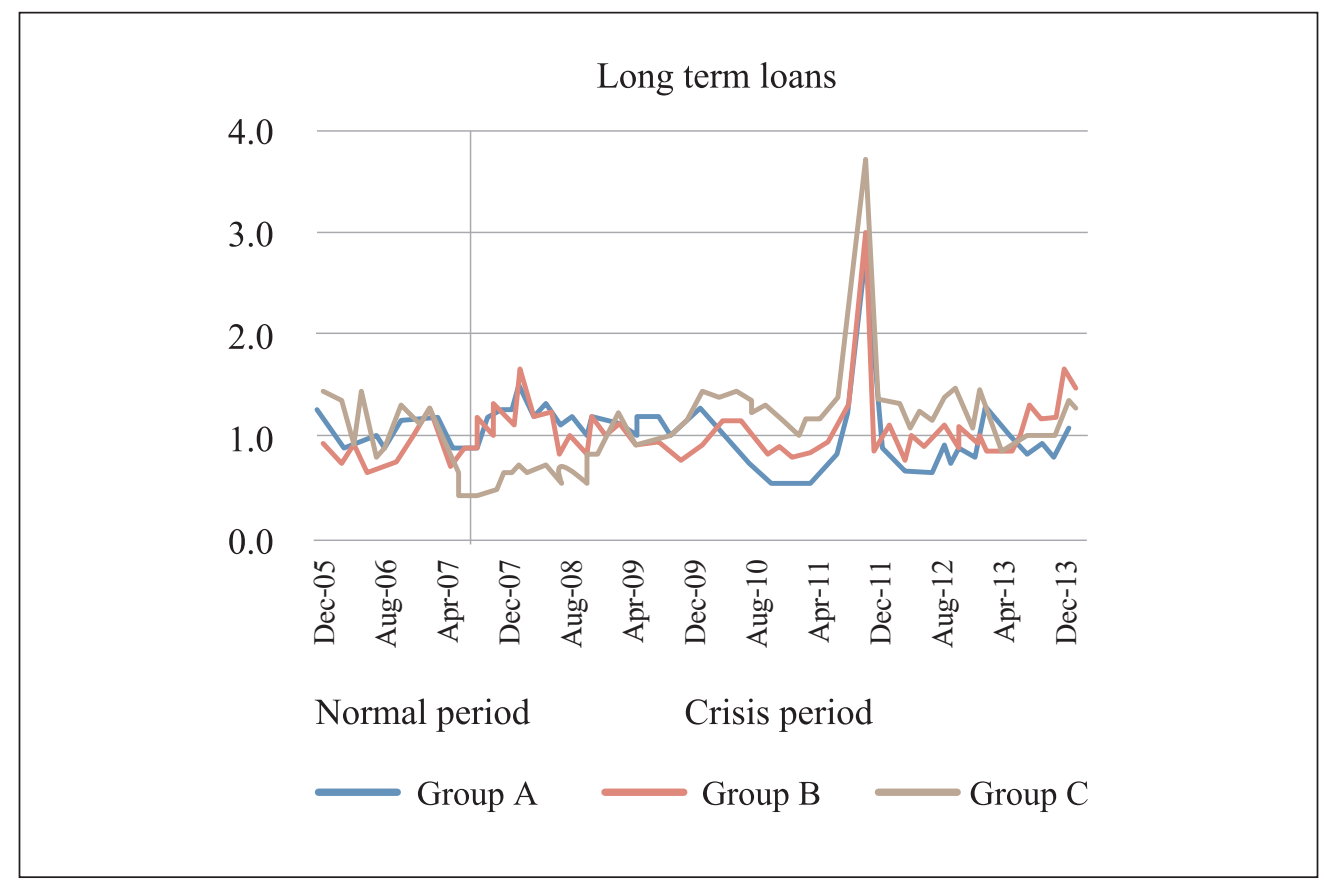

(Note) The figure displays the rolling unweighted average trace statistics (scaled by its critical value) for each group across the sub-periods, namely, normal period and crisis period, separately for deposit and Loan products.

\section{Loans}

For loan products, the analysis shows that overall the loan interest rates do not display co-integration. Figure 11 displays the dynamic co-integration results for short-, medium-, and long-term loan rates for Group A, Group B, and Group C respectively. However, the long-term loans display rather weak signs of co-integration throughout the sample period. While during the period up to the EDC, the Group C economies show the lowest trace statistics, after the onset of the EDC, these economies begin to take the lead. The onset of a crisis does not have any significant impact on the trace statistics. However, we observe an increase in trace statistics toward the end of the sample period, which probably indicates a recovery. Italy, the Netherlands, and Germany show the strongest co-integration. All the economies together briefly display co-integration during the second half of 2011 and the first quarter of 2012. This period coincides with the start of the Eurozone rescue plan and ends with the setting in of pessimism in the system about the bailout fund and the future of the GIIPS economies as they show further signs of distress. 
Figure 12. Coefficient of error correction term of loans
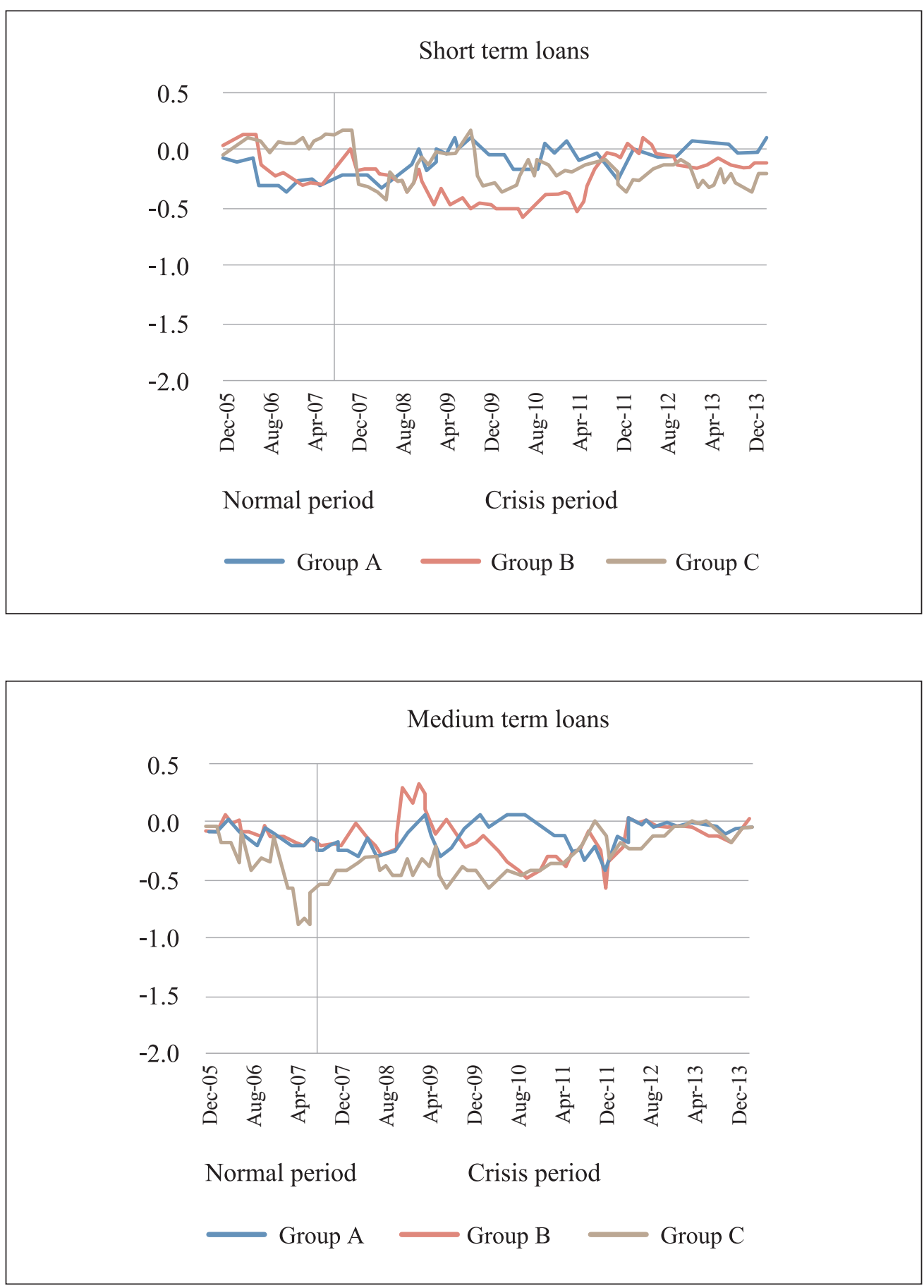


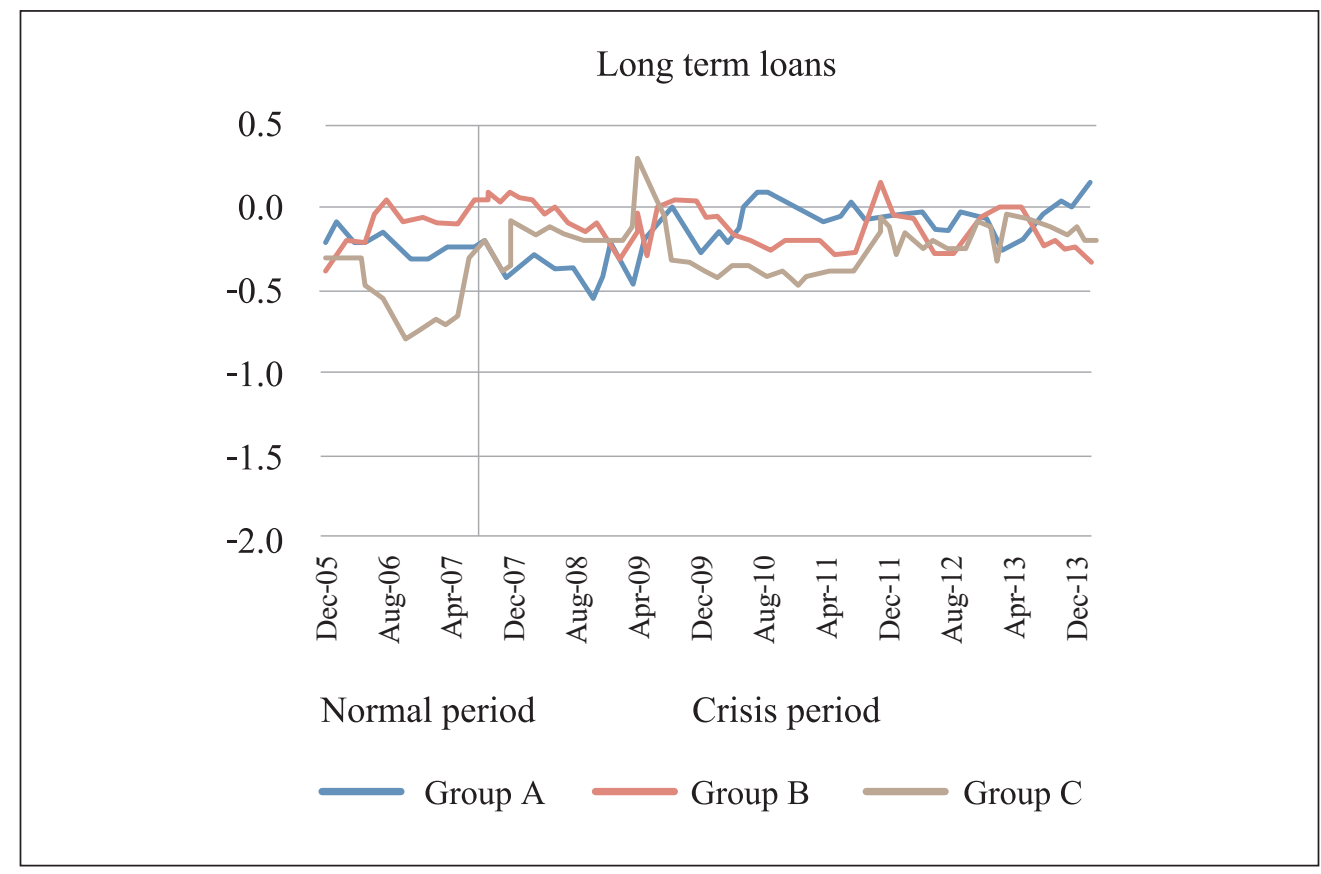

(Note) The figure displays the unweighted average of the absolute values of rolling coefficient of ECT generated from the dynamic co-integration analysis, for each group across the sub-periods, namely, normal period and crisis period, separately for deposit and loan products.

Further, the ECT results (Figure 12) demonstrate that the speed of adjustment across all maturities is negligibly low and remains below 0.3 in magnitude. All the groups show similar, negligible magnitude of the speed of adjustment toward long-run equilibrium. There is evidence of a further drop in the magnitude toward zero with the onset of the EDC.

Finally, for all products, the long-term deposit rates demonstrate the lowest degree of integration as compared to short and medium term. The long-term rates also seem to be less efficient than the other maturities, in terms of adjustment after a shock and sensitivity and reaction to a crisis. 


\section{Conclusion}

This paper assesses multiple dimensions of time-varying integration in the retail banking sector of the EMU during normal and Crisis periods, by analyzing deposit and lending rates to NFC. The results suggest that the degree of integration in retail banking, with a focus on NFCs, in the Eurozone is rather weak. We observe considerable heterogeneity across countries, despite the zone having a single currency, a common central bank and relatively smooth cross-country trade and investments, which are seen as unifying forces that stimulate banking integration. It has important implications for the implementation of the proposed banking union in the region. The hurdles to retail banking integration include customer-specific reasons, such as home bias, consumer trust, access of local banks to confidential information about the creditworthiness of borrowers, and customized bundling of products and services chargeable at different rates in different markets (Barros et al. 2005). In addition, market-specific reasons such as diverse banking structures, competition in the banking sector, government intervention, financial market development, regulation and supervision also act as hurdles to retail banking integration. Varying domestic economic characteristics, such as inflation and credit risk, also leads to differences in interest rates across economies. Other issues that need attention for an effective banking union include addressing the political barriers to entry, particularly the inclination of some national authorities to prevent the foreign takeover of large national banks (Weill 2009). For example, in 2005, the Bank of Italy blocked the acquisition of Banca Antonveneta and Banca Nazionale de Lavoro by the Dutch bank ABN Amro and the Spanish bank Banco Bilbao Vizcaya Argentaria, respectively, to protect these domestic banks from foreign investors (Köhler 2009).

Across all the products on both the credit and the savings side for NFCs, retail banking integration is strongest for Group A countries, which consists of large-sized economies, while Group C countries, which consists of small-sized economies, showed almost negligible convergence. Of the three groups, the convergence level of Group $\mathrm{C}$ was the worst affected by the crisis, particularly the EDC. This indicates a positive relationship between economic size and banking sector convergence. As the largesized economies typically have stable macroeconomic systems, better institutional and regulatory structures and greater cross-border trade and investments, these are better converged.

Two countries emerged as exceptional when compared with other economies in 
terms of integration. First, the results reveal that the retail banking system of France demonstrates the highest degree of integration with the euro banking system. It is noteworthy that out of the 10 largest banks in Europe by total assets, four belong to France (SNL 2015). Since the introduction of the euro, French banks have remained the most ambitious and have undertaken aggressive cross-border acquisitions. They are the largest holders of public and private debt in the euro area, including that of the troubled GIIPS economies, which has increased the vulnerability of French banks to default.

Second, the empirical results show that amongst the Group C economies, Luxemburg emerged as more integrated than other economies in the group. Luxemburg displays Group B like integration levels. This can be attributed to the fact that Luxemburg has a long history of being the leading financial center of Europe. Moreover, in terms of banking assets to GDP, Luxembourg has the largest banking sector, whose banking sector driven by foreign banks, while for most other economies the focus is on domestic operations (ECB 2013).

In addition, it is noteworthy that the troubled economies of GIIPS show signs of distress in the process of retail banking integration during the Crisis period. This may be attributed to the discriminatory investment approach of investors in these countries, corresponding to their perception of higher sovereign risk attached with these economies.

At the product level, the results across all indicators allow us to conclude that the deposit market is more integrated than the loans market. Moreover, the speed of adjustment of lending rates to long-run equilibrium rates is negligible compared to deposit rates, indicating an inefficient adjustment process for loan products in the region. Key reasons for heterogeneity in the lending rates across countries include the varying degree of competition faced by banks and the different bargaining power of NFCs, given their access to other sources of funding such as the capital market. Bank-client relationships form an integral part of the banking business; thus, corporations having a long relationship with a particular bank and better credit standing are often able to negotiate better loan conditions and lower interest rates. The bank-client relationships are often local in nature, as factors such as sharing of cultural norms and language play a vital role in building and strengthening such relationships. Language barriers also create significant hurdles in the formal documentation process, if the contracts are stated in the local language. It creates friction in the process and an unequal playing field for foreign banks. This is particularly true for EMU countries where local languages are the primary language of communication as well as for legal and contractual purposes.

In addition, maturity of the product and degree of integration are observed to be 
inversely related as short-term maturity products are better converged than mediumand long-term products. Long-term rates reflect market expectations of future inflation, economic developments, and interest rates set by central banks. Hence, by inference, long-term interest rates are determined by country-specific economic conditions, which explain cross-country differentials and limited convergence in long-term credit. Moreover, the maturity of the loan has a bearing on the determination of lending rates as longer maturity is associated with increased risk factors. Thus, the lending rate also includes a premium for higher risk. The results reveal that the degree of integration for all products across all countries deteriorated during the Crisis periods, particularly during the EDC. The short- and medium-term products are seen to be more affected than longterm rates. The long-term rates are observed to be less efficient than other maturities in terms of adjustment after a shock.

Strong integration is important for stability in retail banking, as higher cross-border banking ensures that it is not entirely linked to the business cycle of the domestic economy. While increase in retail banking integration is a desirable step toward an effective banking union and integrated real economies, the recent crises have revealed that an interdependent regional banking system also poses a threat of systemic risk. It has the potential of leading to a credit crunch in the inter-connected economies of the region as the real economy and the banking industry are pro-cyclical, wherein excessive credit is made available during upturns while downturns are accompanied by strict lending standards (Goddard, Molyneux, Wilson and Tavakoli 2007). An integrated banking system in Europe calls for clearly laid out roles for the ECB and the local fiscal authorities. In addition, an improved distress management mechanism is required with timely sharing of information across borders. The recent crises have encouraged national policy makers to address a number of shortcomings (Moshirian 2011). This has resulted in the emergence of new rules, reforms, and institutions such as the Financial Stability Board, Capital Market Union, and Banking Union. For capital markets, the proposal adopted in February 2015 to create a Capital Market Union aims at a single capital market, less fragmentation, diverse financing sources, stronger cross-border capital flows and improved access to finance for businesses, particularly SMEs. These initiatives along with steps such as a single supervisory mechanism for banks in the EMU from November 2014, stress-test exercises and greater coordination on crisis management and pressure to comply with Basel III is expected to contribute toward the long-run goal of a banking union in Europe. 
Received 9 March 2016, Revised 1 July 2016, Accepted 19 July 2016

\section{References}

Affinito, M., and Farabullini, F. "An empirical analysis of national differences in the retail bank interest rates of the euro area." Temi di discussione Bank of Italy, 589 (2006). Accessed, 20 February 2013, https://www.bancaditalia.it/pubblicazioni/temidiscussione/2006/2006-0589/tema_589.pdf.

Angelini, P, Nobili, A. and Picillo, C. "The Interbank Market after August 2007: What Has Changed, and Why?" Journal of Money, Credit and Banking, 43 (2011): 923-958.

Baele, L., Ferrando, A., Hordahl, P., Krylova, E., \& Monnet, C. "Measuring Financial Integration in the Euro Area." ECB Occassional Paper 14(2004). Accessed 12 June 2013, https:/www.ecb.europa.eu/pub/pdf/scpops/ecbocp14.pdf?b767d42e5483e5b763fa 750317025 ed 4 .

Barro, R. J., and Sala-i-Martin, X. "Convergence." Journal of Political Economy 100 (1992): 223-251.

Baumohl, E. "Stock market integration between the CEE-4 and the G7 markets: Asymmetric DCC and smooth transition approach." MPRA Paper No. 43834 (2013). Accessed, 13 October 2013, https://mpra.ub.uni-muenchen.de/id/eprint/43834.

Bondt, G. de. "Interest rate pass-through: empirical results for the euro area." German Economic Review 6 (2005): 37-78. DOI: 10.1111/j.1465-6485.2005.00121.x

Buchholz, M., and Tonzer, L. "Sovereign Credit Risk Co-movements in the Eurozone: Simple Interdependence or Contagion." European University Institute Working Paper (2013). Accessed, 15 July 2015, http://econstor.eu/bitstream/10419/100443/1/ VfS_2014_pid_443.pdf

Buttner, D., and Hayo, B. "News and correlations of CEEC-3 financial markets." Economic Modelling 27 (2010): 915-922.

Cabral, I., Dierick, F., and Vesala, J. "Banking Integration in the Euro Area." ECB Occasional Paper Series 6 (2002). Accessed, 10 September 2012, http://ssrn.com/ 
abstract $=748969$.

Campa, Jose Manuel and Gonzalez Minguez, Jose M. "Differences in exchange rate pass-through in the euro area." European Economic Review 50 (2006): 121-145.

Cappiello, L., Engle, R. H., and Sheppard, K. "Asymmetric dynamics in the correlations of global equity and bond returns." Journal of Financial Econometrics 4 (2006), 537-72.

Casu, B., and Girardone, C. "Integration and efficiency convergence in EU banking markets." Omega 38 (2010): 260-267.

ECB. (2013). Banking Structures Report, 2013. Frankfurt am Main: European Central Bank.

Eppendorfer, C., Beckmann, R., \& Neimke, M. "Market Access Strategies in the EU Banking Sector-Obstacles and Benefits towards an Integrated European Retail Market." In The Incomplete European Market for Financial Services, pp. 65-87. Physica-Verlag HD, 2003.

Fung, L. K. P., Tam, C. S. and Yu, I. W. (2008). "Assessing the integration of Asia's equity and bond markets." Bank for International Settlement paper 12 (2008).

Goddard, J., Molyneux, P., Wilson, J. O., and Tavakoli, M. "European banking: An overview." Journal of Banking and Finance 31 (2007): 1911-1935.

Gropp, R., \& Kashyap, A. "A New Metric for Banking Integration in Europe". NBER Working Paper 14735 (2009). Accessed 28 August 2013, http:/www.nber.org/papers/ w14735

Gropp, R., Sørensen, C. K., and Lichtenberger, J.-D. "The Dynamics of Bank Spreads and Financial Structure." ECB Working Paper 714 (2007). Accessed, 13 September 2013, http://www.ecb.europa.eu/pub/pdf/scpwps/ecbwp714.pdf

Heinemann, F., and Jopp, M. "The benefits of a working European retail market for EU financial services." Institut fur Europaische Politik, Berlin Working Paper (2002). Accessed, 26 December 2015 from http://econstor.eu/bitstream/10419/110486/ 1/821652427.pdf

Ilut, B. and Chirlesan, D. "Developments in the banking integration process of the new EU member states." Procedia - Social and Behavioral Sciences, 62 (2012): 457 - 461.

Johansen, S. "Estimation and Hypothesis Testing of Cointegration Vectors in Gaussian 
Vector Autoregressive Models." Econometrica, 59 (1991): 1551-1580.

Kleimeier, S., and Sander, H. "Regional versus global integration of euro-zone retail banking markets: Understanding the recent evidence from price-based integration measures." The Quarterly Review of Economics and Finance 46 (2006): 353-368.

Köhler, M. "Merger Control as Barrier to EU Banking Market Integration." Center for European Economic Research (ZEW) Discussion Paper (2009). Accessed, 09 October 2013, http://econstor.eu/bitstream/10419/29640/1/616485557.pdf.

Langfield, S., and Pagano, M. "Bank bias in Europe: effects on systemic risk and growth." ECB Working Paper 1797 (2015): 1-61. Accessed, 3 March 2014, http://ssrn. com/abstract $=2621554$.

Manna, M. " Developing statistical indicators of the integration of the euro area banking system." European Central Bank Working Paper, 300 (2004). Accessed, 02 July 2013, http://www.ecb.europa.eu/pub/pdf/scpwps/ecbwp300.pdf.

Martın-Oliver, A., Saurina, J., and Salas-Fuma, V. "Interest rate dispersion in deposit and loan markets." Documentos de Trabajo, 0506 (2005). Accessed, (10 July 2015) from http://www.bde.es/f/webbde/SES/Secciones/Publicaciones/PublicacionesSeriadas/ DocumentosTrabajo/05/Fic/dt0506e.pdf

Mylonidis, N., and Kollias, C. "Dynamic European stock market convergence: Evidence from rolling cointegration analysis in the first euro-decade. " Journal of Banking and Finance 34 (2010): 2056-2064. DOI: 10.1016/j.jbankfin.2010.01.012

Nelson, D.B. "Conditional Heteroskedasticity in Asset Returns: A New Approach." Econometrica 59 (1991): 347-370.

Perez, D., Vicente, S.F., and Saurina, J. "Banking Integration in Europe." Banco De España Working Paper 0519 (2005): 1-41. Accessed, 30 August 2013, http:// www.bde.es/f/webbde/SES/Secciones/Publicaciones/PublicacionesSeriadas/ DocumentosTrabajo/05/Fic/dt0519e.pdf

Rughoo, A., and Sarantis, N. "Integration in European retail banking: Evidence from savings and lending rates to non-financial corporations." Journal of International Financial Markets, Institutions and Money, 22 (2012): 1307-1327.

Rughoo, A., and Sarantis, N. "The global financial crisis and integration in European 
retail banking." Journal of Banking and Finance 40 (2014): 28-41.

Sander, H., and Kleimeier, S. "What interest rate pass-through tells us about monetary policy transmission, competition and integration". Journal of International Money and Finance (2004): 461-492.

Schuler, M., and Heinemann, F. "How integrated are European retail financial markets? A cointegration analysis." Working Paper, Centre for European Economic Research (2002).

Serletis, A. and M. King. "Common Stochastic Trends and Convergence of European Union Stock Markets." Manchester School, 65 (1997): 44-57.

Simplice, A. "Globalization, financial crisis and contagion: time-dynamic evidence from financial markets of developing countries." Journal of Advanced Studies in Finance 3 (2012): 131-139.

SNL. (2015, June 29). Top 50 European banks by total assets. Accessed, from SNL Financial: https://www.snl.com/InteractiveX/Article.aspx?cdid=A-32694538-12072

Taylor, M. P., and Tonks, I. "The Internationalisation of the Stock Markets and the Abolition of U.K. Exchange Control." The Review of Economics and Statistics 71 (1989): 332-336.

Trichet, J.-C. "State of the Union: The Financial Crisis and the ECB's Response between 2007 and 2009." Journal of Common Market Studies 48 (2010): 7-19.

Wehinger, G. "Bank deleveraging, the move from bank to market-based financing, and SME financing." OECD Journal: Financial Market Trends 1 (2012): 1-16.

Weill, L. "Convergence in banking efficiency across European countries." Journal of International Financial Markets, Institutions \& Money 19 (2009): 818-833. 